\title{
ANELÍDEOS POLIQUETAS DO NORDESTE DO BRASIL. I - POLIQUETAS BENTÔNICOS DA COSTA DE ALAGOAS E SERGIPE
}

\author{
(Recebido em 8/6/1970)
}

Edmundo F. Nonato

Instituto Oceanográfico da Universidade de São Paulo

$\&$

José Audísıo C. LuNa

Laboratório de Ciências do Mar da Unicersidade Federal de Pernambuco

\section{SYNOPSIS}

This is the second report dealing with the oenthic Polychaeta collected on the continental shelf of the north-eastern Brazil (approximately between $90^{\circ}$ and $110^{\circ}$ of latitude south), by the Laboratório de Ciências do Mar (formerly Instituto Oceanográfico) of the Universidade Federal de Pernambuco. 1969).

In the first one we discussed only the scale-bearing species (Nonato \& Luna,

Data concerning the area sampled by the Laboratório de Ciências do Mar can be found in the papers of CAVAlCantr et al. and Mabesoone \& TrNoco, 1967.

The present paper is about the scale-free species, in number of 71 .

Almost all the smaller species we can expect to find in similar areas, seem to be absent here. This may be due to their actual rarity or, most probably, to their destruction during sampling and sorting.

The hard bottom prevailing in the area, which has a very rough surface, shaped by blocks and pebbles of calcareous algae and corals make the biological sampling a hard enterprise. It is particularly difficult to preserve the integrity of soft-bodied animals, such as the polychaetes, against the grinding action of the material inside the sampling devices.

We must remember this exceptional condition when judging the apparent scarceness of the polychaetes. If the worm fauna of that region seems, at the first approach, very poor, in reality it may be not.

In consequence we hope the use of improved methods of sampling will give far better results. The night fishing, with a submerged light, for example, may be a choice method to attract many species from the ground or from the otherwise unaccessible hide-outs.

From the 71 species, only one has been considered as new for the science. Scoloplos agrestis $s p$. nov, approaches S. robustus Rullier and S. madugascarensis Fauvel, but differ from them by the number of the thoracic setigers (only 15) and by the number of accicular setae of the thoracic neuropodia (only 5 or 6).

The Eunicea is the best represented group, with 26 species; the commonest being Eunice longicirruta Webster (108 specimens, in 19 stations).

Diopatra spiribranchis Augener and also Hypsicomus elegans Webster are considered as good species.

Only two flabelligerids were caught in the whole area; one of them is a well preserved specimen of Pherusa scutigera (Ehlers) and the other a damaged specimen of Piromis $s p$.

The greatest part of the present species is believed to be similar to those found in the Caribbean area, as we should expect. But a few show a great similarity with Pacific and Indian species. Some of them, as Glycera longipinnis Grube, Onuph is litoratis Monro and Vermiliopsis acanthophora Augener, agree closely with the available descriptions.

Publ. n.o 299 do Inst. Ocean. da USP. 


\section{INTRODUÇÃO}

Em 1965 o Laboratório de Ciências do Mar (então Instituto Oceanográfico) da Universidade Federal de Pernambuco, na execução de um plano de estudo da plataforma continental do Nordeste do Brasil, realizou uma série de cruzeiros de exploração e coleta sistemática, ao longo da costa dos Estados de Sergipe e Alagoas (Cavalcanti et al., 1967).

N'uma outra série de cruzeiros, realizados durante os anos de 1965 e 1966, a área de exploração foi ampliada até o Ceará.

As duas séries são aqui designadas pelo nome das embarcações utilizadas em cada uma delas, os arrastóes de pesca AKAROA, durante a primeira e CANOPUS, na segunda.

Nessa área foram realizadas 190 estações, distribuídas em linhas perpendiculares à costa, em profundidades geralmente de 10 a $50 \mathrm{~m}$ e, excepcionalmente (na foz do rio São Francisco), até $720 \mathrm{~m}$.

Anelídeos poliquetas ocorreram nas amostras de 112 estações do AKAROA e em 7 das estações repetidas pelo CANOPUS, na mesma área (Mapa 1).

N'um exame preliminar dêsse material, constatamos a presença de 93 espécies pertencentes a 32 famílias (LunA, 1969).

As espécies de escamas, em número de 15, foram descritas n'um trabalho anterior (Nonato \& LunA, 1969). As demais, que um estudo pormenorizado revelou serem em número de apenas 71 , constituem o objeto dêste trabalho.

Características da área amostrada - De acôrdo com Cavalcanti et al. (1967, p. 137) a plataforma continental ao longo dos Estados de Alagoas e Sergipe (aproximadamente entre as latitudes $8^{\circ} 50^{\prime}$ e $\left.11^{\circ} 20^{\prime} \mathrm{S}\right)$, é estreita, com sua ruptura para o talude a uns $50.60 \mathrm{~m}$ de profundidade. O seu relêvo é bastante plano nas profundidades de $25.50 \mathrm{~m}$, existindo em frente ao rio São Francisco um canyon.

Os fundos predominantes são os constituídos por conglomerados de algas calcárias; os fundos de areia, geralmente de origem orgânica ("areia de Halimeda"), são mais raros. Fundos detríticos e de lama ocorrem na foz do rio São Francisco.

Exceto nas áreas de influência do rio, a temperatura e a salinidade junto ao fundo variam muito pouco. Os dados obtidos a $25 \mathrm{~m}$ de profundidade mostram que a salinidade é aproximadamente constante, em redor de $36 \%$ e que a temperatura oscilou entre $25,5^{\circ}$ e $26,0^{\circ} \mathrm{C}$ (meses de agôsto e setembro; Cavalcanti et al., p. 144-148).
Material e métodos - As amostras de fundo foram obtidas com dragas de arrasto convencionais. Os resultados foram muito satisfatórios, tendo em conta a dificuldade da amostragem em fundos duros. Porém, é necessário lembrar que a natureza do subs. trato predominante na área tornou, muitas vêzes, difícil a preservação de espécies pequenas ou delicadas. Conseqüentemente, era previsivel que estas fôssem modestamente representadas na coleção atual; como na realidade ocorreu.

Técnicas mais requintadas, visando especificamente a coleta de poliquetas proporcionarão, certamente, resultados compensadores. Dentre tais técnicas, as coletas de plâncton e a pesca com luz, em pequenas profundidades, permitirão complementar a amostragem de uma área que se revelou extremamente promissora.

Na descrição são indicadas, para cada espécie, as características dos exemplares examinados, a profundidade e o tipo de fundo da estação de coleta, AK indicando a série do "Akaroa" e CAN a do "Canopus".

O tipo de fundo é indicado de acôrdo com a convenção seguinte:

$$
\begin{aligned}
& \text { A — areia } \\
& \text { B - Bryozoa } \\
& \text { D - fundo detrítico } \\
& \text { H - areia de Halimeda } \\
& \text { L - lama } \\
& \text { R - rocha } \\
& \text { ACL - algas calcárias livres } \\
& \text { BAC - blocos de algas calcárias }
\end{aligned}
$$

O critér:o taxonômico adotado para as famílias é o de Hartman, conforme expresso em seu Catalogue of the polychaetous annelids of the world (1959).

Agradecimentos - Ao Dr. Marc Kempf agradecemos a ajuda prestada pelo fornecimento dos dados utilizados. Agradecemos ao licenciado Pierre Montouchet o preparo dos desenhos das espécies aqui descritas e a todos aquêles que, direta ou indiretamente contribuíram para a realização do presente trabalho.

O material foi depositado no Museu do Laboratório de Ciências do Mar da Universidade Federal de Pernambuco. 


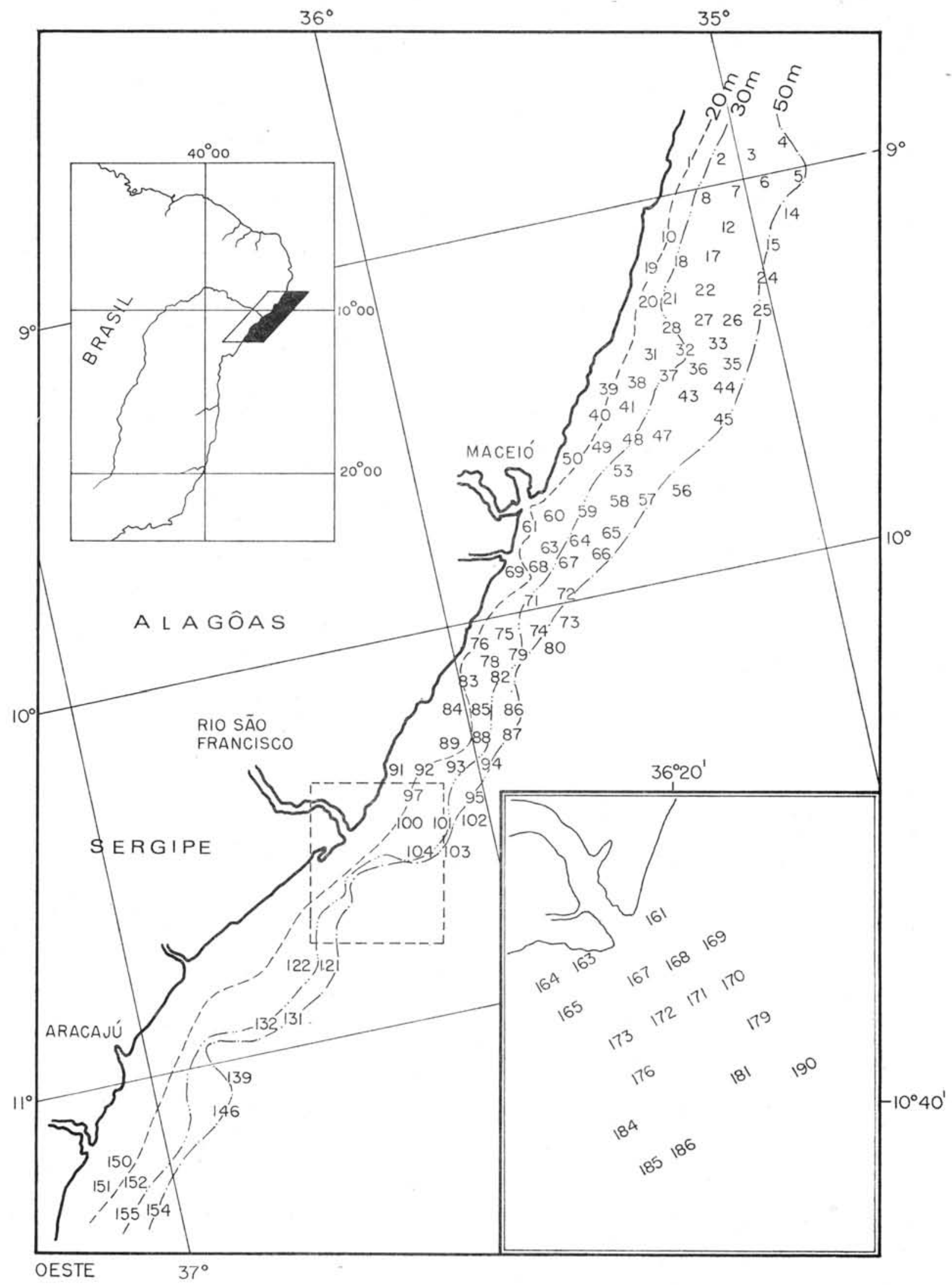

Mapa 1 - Localização das estacões do «AKAROA» nas quais foram coletados anelídeos poliquetas. 


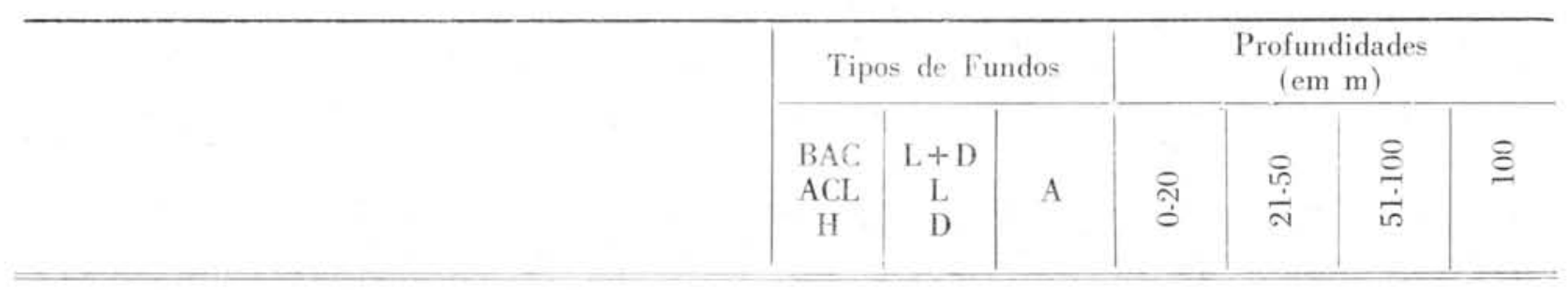

\section{APHRODITIDAE}

Pontogenia chrysocoma (Baird)

\section{POLYNOIDAE}

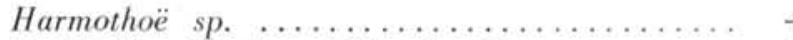

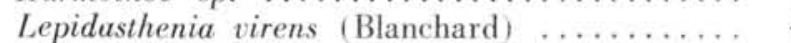

Lepidonotus caeruleus Kinberg ........... -

\section{POLYODONTIDAE}

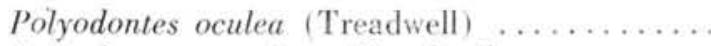

Polyodontes pustulata (Treadwell)

\section{SIGALIONIDAE}

Psammolyce arenosa (delle Chiaje) ..........

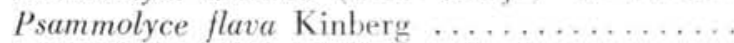

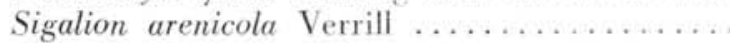

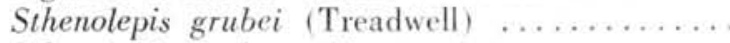

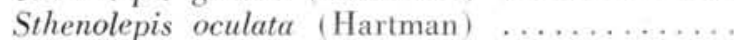

Thalenessa lewisii (Berkeley)

\section{PAREULEPIDAE}

Pareulepis fimbriata (Treadwell)

\section{AMPHINOMIDAE}

Chloeia viridis Schmarda ................

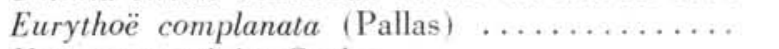

Notopygos crinita Grube

\section{PHYLLODOCIDAE}

Anaitides madeirensis (Langerhans) .......... Eulalia cf. bilineata (Johnston) ........... +

\section{HESIONIDAE}

Hesione picta Fritz Müller ............. +

\section{PILARGIDAE}

Synelmis albini (Langerhans)

\section{SYLLIDAE}

Typosyllis prolifera (Krohn)

Typosyllis variegata (Grube)

\section{NEREIDAE}

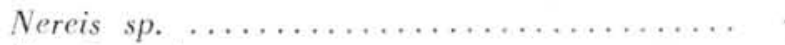

Pseudonereis sp. ...................

\section{NEPHTYIDAE}

Nephtys squamosa Ehlers

\section{GLYCERIDAE}

Glycera americana Leidy

Glycera longipinnis Grube

$\begin{array}{lllllll}+ & + & - & + & + & + & - \\ + & - & - & - & + & - & - \\ + & - & - & + & + & - & -\end{array}$

$+$




\begin{tabular}{|c|c|c|c|c|c|c|}
\hline \multicolumn{3}{|c|}{ Tipos de Fundos } & \multicolumn{4}{|c|}{$\begin{array}{l}\text { Profundidades } \\
\qquad(\mathrm{em} \mathrm{m})\end{array}$} \\
\hline $\begin{array}{c}\mathrm{BAC} \\
\mathrm{ACL} \\
\mathrm{H}\end{array}$ & $\begin{array}{c}\mathrm{L}+\mathrm{D} \\
\mathrm{L} \\
\mathrm{D}\end{array}$ & A & 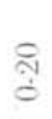 & $\frac{\text { กิ }}{\frac{1}{2}}$ & $\frac{8}{15}$ & $\S$ \\
\hline
\end{tabular}

\section{ONUPHIDAE}

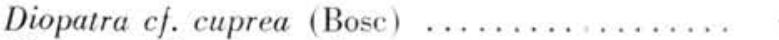

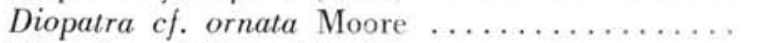

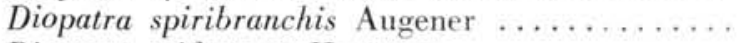

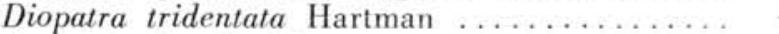

Onuphis litoralis Monro ................ +

\section{EUNICIDAE}

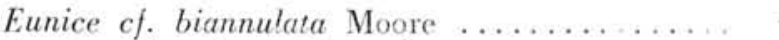

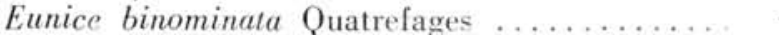

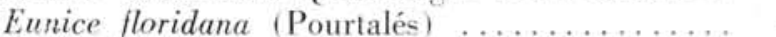

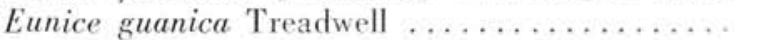

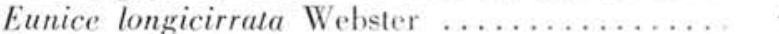

Eunice rubra Grube ..................... +

Eunice cf. tridentata Ehlers ....................

Eunice cf. vittata (delle Chiaje) ..............

Eunice (Nicidion) cariboea Grube .............

Eunice (Nicidion) imogena Monro ............

Eunice (Nicidion) kinbergi Webster ..........

Lysidice ninetta Aud. \& M. Edw. . . . . . . . .

Marphysa regalis Verrill ................

Marphysa stylobranchiata Moore ............

Palola siciliensis (Grube)

$\begin{array}{ll}+ & + \\ + & + \\ + & + \\ + & +\end{array}$

$\begin{array}{llll}+ & - & + \\ + & - & - & + \\ + & - & -\end{array}$

$\begin{array}{lll}+ & - & - \\ + & - & - \\ + & - & - \\ + & - & - \\ + & - & -\end{array}$

LUMBRINERIDAE

Lumbrineris cingulata Treadwell ............ Lumbrineris cf. cruzensis Hartman ......... + Lumbrineris latreilli Aud. \& M. Edw. ....... + Lumbrineris treadwelli Hartman ............

ARABELLIDAE

No:ocirrus cf. lorum Ehlers

DORVILLEIDAE

Dorvillea cf. moniloceras (Moore) ........... +

ORBINIIDAE

Scoloplos agrestis sp. not. .............. - + + + +

CHAETOPTERIDAE

Mesochaetopterus sp. ................. + Phyllochaetopicrus cf. gracilis Grube .........

Telepsavus sp.

CIRRATLLIDAE

Tharyx sp.

\section{FLABELLIGERIDAE}

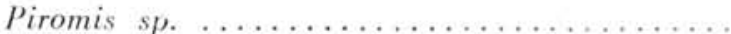

Pherusa scutigera (Ehlers) 


\begin{tabular}{|c|c|c|c|c|c|c|c|}
\hline \multirow[t]{2}{*}{. } & \multicolumn{3}{|c|}{ Tipos de Fundos } & \multicolumn{4}{|c|}{$\begin{array}{l}\text { Profundidades } \\
\quad(\mathrm{em} \mathrm{m})\end{array}$} \\
\hline & $\begin{array}{c}\mathrm{BAC} \\
\mathrm{ACL} \\
\mathrm{H}\end{array}$ & $\begin{array}{c}\mathrm{L}+\mathrm{D} \\
\mathrm{L} \\
\mathrm{D}\end{array}$ & A & ণ্ণ & ํํㄹ & $\begin{array}{l}8 \\
\stackrel{8}{\ddot{1}} \\
\text { ம }\end{array}$ & $\stackrel{8}{8}$ \\
\hline
\end{tabular}

\section{OPHELIIDAE}

- Armandia cf. agilis (Andrews) ............ Armandia maculata (Webster) .............. Armandia polyophthalma Kükenthal ......... + Armandia sp. .................... -

Ophelia formosa (Kinberg) .............

\section{STERNASPIDAE}

Sternaspis capillata Nonato

\section{CAPITELLIDAE}

Dasybranchus sp.

\section{OWENIIDAE}

Owenia fusiformis delle Chiaje

\section{PECTINARIIDAE}

Fragmentos de tubos

\section{AMPHARETIDAE}

Amphicteis gunneri (Sars)

\section{TEREBELLIDAF}

Pista cf. cristata (F. Müller) ............. -

Pista sp. ........................

Streblosoma cf. bairdi (Malmgren) .......... +

Thelepus sp. $\ldots \ldots \ldots \ldots \ldots \ldots \ldots \ldots \ldots \ldots \ldots \ldots \ldots \ldots+$

\section{TRICHOBRANCHIDAE}

Terebellides anguicomus F. Müller

\section{SABELLIDAE}

Hypsicomus circumspiciens Ehlers ......... Hypsicomus elegans (Webster) ........... + Laonome sp. ................... Megalomma bioculatum (Ehlers) ..........+ +

\section{SERPULIDAF}

Crucigera websteri Benedict ........... -

Hydroides californicus Treadwell .......... -

Serpula vermicularis Linneu ............ -

Vermiliopsis acanthophora Augener ......... + 
Família APHRODITIDAE Malmgren 1867

Gênero Pontogenia Claparède 1868

Pontogenia chrysocoma (Baird) 1865

Hermione chrysocoma Baird, 1865.

Pontogenia chrysocoma (Baird). Fauvel, 1923, p. 38, fig. 13, a-f. Rullier, 1965, p. 16. Day, 1967, p. 35 , fig. I.I, r-v.

4 exemplares completos (AK 06, BAC; AK 32, BAC; AK 59, ACL e AK 73, L) medindo, respectivamente, $15,25,18$ e $16 \mathrm{~mm}$.

Distribuição - Mediterrâneo. Costa atlântica da África; Rio de Oro, Principe, Dahomey (Rullier, 1965). África do Sul. Zanzibar, Madagascar (Day, 1967). Nordeste do Brasil (Alagoas).

Família POLYNOIDAE Malmgren 1867

Gênero Harmothoë Kinberg 1855

Harmothoë sp.

1 único exemplar (AK 56, BAC) com 36 setígeros anteriores, medindo $16 \mathrm{~mm}$ de comprimento; tôdas as escamas perdidas.

Gênero Lepisdasthenia Malmgren 1867

Lepidasthenia virens (Blanchard) 1849

Polynö virens Blanchard, 1849.

Lepidasthenia virens (Blanchard). Hartman, 1939, p. $46-47$, est. 8, fig. 105-110.

Lepidasthenia irregularis Ehlers, 1901, p. 54-55, est.

3 , fig. 10-16.

Lepidasthenia berkeleyae Luna, 1969.

4 exemplares sendo 3 presumivelmente completos, fragmentados (AK 31, BAC) e um exemplar incompleto, com 34 setígeros, macerado (AK 48, BAC). 0 maior exemplar, com cêrca de 80 setígeros, mede $52 \mathrm{~mm}$ de comprimento.

Distribuição - Chile, Equador, México ocidental, Galapagos (segundo Hartman, 1939). Nordeste do Brasil (Alagoas).

Gênero Lepidonotus Leach 1816

Lepidonotus caeruleus Kinberg 1855

Lepidonotus caeruleus Kinberg, 1855. 1910, p. 13-14, est. 4, fig. 16; est. 10, fig. 51. Hartman, 1948, p. 22-23.

3 exemplares completos (AK 19, A; AK 21, H e AK 83, D) medindo, respectivamente, 22, 10 e 15 mm de comprimento.

- Distribuição - Brasil; costa sul (Rio de Janeiro) e nordeste (Alagoas).
Família POLYODONTIDAE Pflugfelder 1934

Gênero Polyodontes Renier 1832

Polyodontes oculea (Treadwell) 1902

Panthalis oculea Treadwell, 1901, p. 188-189, fig. 14-18.

Polyodontes oculea (Treadwell). Monro, 1928, p. 572-575, fig. 25-30. Hartman, 1939, p. 83-84, est. 24, fig. 294-299. 1942, p. 125.

Panthalis panamensis Chamberlin, 1919, p. 86-89, est. 11, fig. 48 ; est. 12, fig. 1-6.

2 exemplares incompletos (AK: $10^{\circ} 37^{\prime} \mathrm{S} \cdot 36^{\circ} 38^{\prime} \mathrm{W}$; rêde de arrasto), com 65 e 68 setígeros anteriores, medindo cêrca de $70 \mathrm{~mm}$ de comprimento e $13 \mathrm{~mm}$ de largura (sem os pés).

Distribuição - Pacífico: Panamá, Califórnia, México. Atlântico: Antilhas (Pôrto Rico), Nordeste do Brasil (foz do rio S. Francisco).

Polyodontes pustulata (Treadwell) 1924

Panthalis pustulata Treadwell, 1924, p. 7.9, fig. 10 .

15. Renaud, 1956, p. 4-6, fig. 3.

Acoetes magnifica Treadwell, 1929. Hartman, 1939, p. 83 e 87. 1959, p. 109.

Panthalis sp. Luna, 1969.

1 exemplar incompleto (AK 100? R) com 41 segmentos anteriores, medindo $16 \mathrm{~mm}$ de comprimento e $3,5 \mathrm{~mm}$ de largura (sem os pés).

Distribuição - Antilhas e Nordeste do Brasil (Alagoas).

Família SIGALIONIDAE Malmgren 1867

Gênero Psammolyce Kinberg 1855

Psammolyce arenosa (delle Chiaje) 1841

Sigalion arenosum delle Chiaje, 1841.

Psammolyce arenosa (delle Chiaje). St. Joseph, 1906, p. 150 , est. 1, fig. 7-23; est. 2, fig. 24-31. Fauvel, 1923, p. 106, fig. 40, a-m. Augener, 1933, p. 193-194. Rullier, 1964, p. 138.

Psammolyce kinbergi Hansen, 1882, p. 5, est. 1, fig. 10-13.

Eupholö nuda Treadwell, 1936, p. 53-54, fig. 10-14.

Hartman, 1956, p. 250 e 274.

1 único exemplar, incompleto (AK 72, ACL) com 35 setígeros anteriores, medindo $28 \mathrm{~mm}$ de comprimento.

Distribuição - Atlântico: França, Marrocos, Costa do Ouro, Senegal; Mediterrâneo; Antilhas (Eupholoë nuda); Brasil, costa nordeste e sul.

Psammolyce flava Kinberg 1855 
Psammolyce flava Kinberg, 1910, p. 31-32, est. 9, fig. 44. Hartman, 1942, p. 108-109, fig. 8 h. 1942 b, p. $90-91$, est. 9 , fig. $21 \cdot 23$.

Eupholoë acuminata Treadwell, 1934, p. 3-4, est. 1, fig. 7-8. Hartman, 1956, p. 250.

3 exemplares incompletos (AK 185, D) com 74,44 e 22 setígeros anteriores, medindo respectivamente, $60 \mathrm{~mm}, 45 \mathrm{~mm}$ e $25 \mathrm{~mm}$.

Distribuição - Brasil: Rio de Janeiro e Nordeste. Antilhas: Pôrto Rico e Cuba.

Gênero Sigalion Audouin \& Milne Edwards Sigalion arenicola Verrill 1879

Sigalion arenicola Verrill. Hartman, 1942 a, p. 34,

fig. 44. Pettibone, 1963, p. 48-49, fig. 11, a-b.

2 exemplares incompletos (AK 92, A) com 32 e cêrca de 120 setígeros anteriores, medindo, respectivamente, 25 e $80 \mathrm{~mm}$.

Distribuição - Costa atlântica do Estados Unidos, de Massachusetts à Georgia (Pettibone); Nordeste do Brasil (Alagoas).

Gênero Sthenolepis Willey 1905

Sthenolepis grubei (Treadwell) 1901

Sthenelais grubei Treadwell, 1901, p. 187-188, fig. 10-13.

Eupholö̈ grubei Treadwell, 1939, p. 197, fig. 26, a-b. Leanira grubei (Treadwell). Hartman, 1942, p. 106. .107.

Sthenolepis grubei (Treadwell). Hartman, 1965, p. 54.

Leanira fimbriarum Hartman, 1939, p. 70-72, est. 18, fig. $217-225$.

4 exemplares incompletos, constituídos por frag. mentos anteriores, com 30-39 setígeros; (AK 10, L - 2) e (AK 60, L - 2), o maior medindo $30 \mathrm{~mm}$ de comprimento.

Distribuição - Pôrto Rico; Califórnia, Panamá, Equador (Hartman, 1939). Nordeste do Brasil (Alagoas).

\section{Sthenolepis oculata (Hartman) 1942}

Leanira oculata Hartman, 1942 b, p. 93-95, est. 8, fig. 1-5.

Sthenolepis oculata (Hartman). Hartman, 1965, p. 54 .

1 único exemplar incompleto (AK 170, L), com 82 setígeros anteriores, medindo $40 \mathrm{~mm}$ de compri. mento.
Distribuição - Não encontramos outra referên. cia a $S$. oculata, senão a da descrição original, que dá como localidade tipo — "Off northern Cuba, in $240 \mathrm{fms}$ ".

O nosso material provém das costas do Estado de Alagoas, de uma profundidade de 50 metros.

Gênero Thalenessa Baird 1868

Thalenessa lewisii (Berkeley) 1939

Sigalion lewisii E. e C. Berkeley, 1939, p. 326-328, fig. 2-3. Pettibone, 1967, p. 3.

Eusigalion lewisii (Berkeley). Hartman, 1944, p. 13.

Thalenessa lewisii (Berkeley). Hartman, 1959, p. 119 e 122.

Eusigalion hancocki Hartman, 1939, p. 59-60, est. 12, fig. $141-145$ e 148-152.

Thalenessa hancocki Luna, 1969.

1 exemplar incompleto (AK 89, A) com 75 seg. mentos anteriores, medindo $58 \mathrm{~mm}$ de comprimento.

Distribuição - Gôlfo da Califórnia (Berkeley), Guatemala, México, Equador ("Eastern Pacific", Hartman, 1944), Venezuela. Nordeste do Brasil (Alagoas)

Família PAREULEPIDAE Hartman 1939

Gênero Pareulepis Darboux 1899

Pareulepis fimbriata (Treadwell) 1901

Eulepis fimbriata Treadwell, 1901, p. 190-191, fig. 23-24.

Pareulepis fimbriata (Treadwell). Nonato \& Luna, 1969.

2 exemplares completos (AK 10, L e AK 76, A), com 42 e 39 setígeros, medindo respectivamente 28 e $22 \mathrm{~mm}$.

Em 1969, Pettibone publicou uma revisão da família Eulepethidae Chamberlin (= Pareulepidae Hartman), criando o nôvo gênero Grubeulepis, do qual a espécie-tipo é Eulepis fimbriata Treadwell.

A autora admite (p. 5) a existência de 4 gêneros: Pareulepis Darboux, Grubeulepis n. gen., Eule. pethus Chamberlin (= Eulepis Grube) e Mexieule. pis Rioja. Pareulepis e Grubeulepis diferem quanto às características das escamas:

"Elytra with lateral borders notched $\ldots \ldots \ldots \ldots \ldots \ldots \ldots \ldots$ Pareulepis Elytra with lateral borders

fimbriated (flattened, leaflike processes) Grubeulepis"

A identificação da espécie foi correta e, os nos. sos exemplares, que possuem escamas com o bordo franjado, devem ser incluídos no nôvo gênero, como Grubeulepis fimbriata (Treadwell).

Distribuição - Panamá, Antilhas e Nordeste do Brasil (Alagoas). 
Familia AMPHINOMIDAE Savigny 1818

Gênero Chloeia Savigny 1818

Chloeia viridis Schmarda 1861

(Fig. 1 e 2)

Chloeia viridis Schmarda, 1861, p. 144, est. 25, fig. 295-305. Monro, 1933, p. 9-10, fig. 4. Fauvel e Rullier, 1957, p. 54-57, fig. 2 (sinonímia). Rullier, 1964, p. 144-145.

Chloeia euglochis Ehlers, 1887, p. 18-24, est. 1, fig. 1.2 ; est. 2 , fig. $1-8$; est. 3 , fig. $1-4$.

Chloenea candida Kinberg, 1910, p. 33, est. 11, fig. 2.

5 exemplares completos (AK 04, BAC; AK 14, BAC; AK 60, L; AK 83, D e AK 94, A.L), medindo 28 a $52 \mathrm{~mm}$ de comprimento.

Descrição - Corpo fusiforme, comprimido, com cêrca de 26 setígeros. Prostômio pequeno e arredondado, com dois palpos filiformes; uma antena mediana, longa e duas laterais muito curtas; dois pares de olhos. Carúncula em crista finamente pregueada, longa e subulada; reta ou ligeiramente sinuosa.

Segmentos largos e bem separados. Brânquias dorsais, penadas, a partir do $4 .^{\circ}$ setígero. Cirros dorsais e ventrais muito longos, subulados; nos 2 ou 3 primeiros setígeros os cirros dorsais são duplos. Cerdas muito numerosas, sendo as dorsais bifurcadas em extensão variável. Pigídio com dois uritos grossos, cilíndricos.

Pigmentação (exemplar conservado em álcool) - Antenas e cirros com uma faixa longitudinal violeta; brânquias com a parte central violeta; carúncula com estrias longitudinais, violeta intenso. Sôbre o dorso, ao longo da linha mediana, uma faixa larga, expandida no bordo anterior de cada segmento. Excetuada essa faixa, a superfície do corpo é de côr uniforme, branco-amarelada. reladas.

Cerdas vítreas, incolores ou ligeiramente ama-

Discussão - A distribuição do pigmento em nossos exemplares é semelhante à descrita por MoNro (1933, p. 9, fig. 4, b) em exemplares da costa pacífica do Panamá e por Fauvel e Rullier (1957, p. 55) em espécimens da costa da África; porém limitada na linha mediana, a uma única faixa longitudinal.

Chloenea pallida Kinberg e Chloenea candida Kinberg, respectivamente de Pernambuco e das Antilhas, são conhecidas apenas pelos espécimens em que se basearam as descrições originais. Hartman (1948, p. 37-38) compara ambas com Chloeia viridis Schmarda, concluindo que os exemplares de Kinberg são formas imaturas, presumìvelmente desta espécie.

Chloeia euglochis Ehlers, também da mesma área (Tortugas e Flórida) se distinguiria de viridis apenas pela presença de cerdas ventrais fortemente coradas de vermelho-alaranjado. FAUvel e Rullier (1957, p. 56) constataram que êsse carácter está relacionado com o tamanho do animal e que, numa coleção numerosa podem ser encontrados todos os tipos intermediários entre as cerdas intensamente coradas, dos grandes exemplares e as pràticamente incolores, dos menores.

Distribuição - Atlântico tropical; Mediterrâneo; Índico e Pacífico (Fauvel e Rullier, 1957). Na costa americana; da Flórida até o Nordeste do Brasil (Alagoas).

Gênero Eurythoë Kinberg 1857

Eurythoë complanata (Pallas) 1776

Eurythoë complanata (Pallas). Fauvel, 1953, p. 83, fig. 38, b-m (sinonímia). Hartman, 1968, p. 195, fig. $1 \cdot 4$.

Eurythö̈ brasiliensis Hansen, 1882, p. 4, est. 1, fig. 5.9.

1 exemplar completo (AK 48, BAC) com 35 setígeros, medindo $28 \mathrm{~mm}$ de comprimento.

Descrição - Corpo relativamente curto, de secção retangular. Prostômio grande, arredondado, com quatro olhos sub-iguais, dispostos em quadrado. Antenas piriformes-subuladas. Carúncula bem desenvolvida, alcançando o $5 .^{\circ}$ setígero. Brânquias a partir do $2 .^{\circ}$ setígero; o primeiro par, em forma de filamento simples e curto; as do terceiro setígero, palmadas, com 4 filamentos e as subseqüentes, com 8-12 em tufo compacto.

Ramos parapodiais bem separados, com cirros dorsais e ventrais subulados, medianamente longos. Cerdas notopodiais simples e em harpão; cerdas neuropodiais aciculares, retas e cerdas furcadas, com o ramo maior liso ou denteado.

Côr, no álcool - Branco-amarelado; cerdas branco-alabastro.

Discussão - Eurythoë complanata (Pallas) é uma espécie robusta, que alcança até $25 \mathrm{~cm}$ de compri. mento (DAY, 1967) ; porém espécimens muito menores não são raros. Monro (1930, p. 28) examinou 28 exemplares das Ilhas Ascenção e do Gôlfo da Guiné, dos quais o maior media apenas $30 \mathrm{~mm}$.

Consideramos, porisso, que apesar de seu pequeno tamanho, o nosso exemplar corresponde perfeita. mente às descrições da espécie.

Hartman (1948, p. 42-44) discute 9 espécies de Kinberg, das Antilhas, Pacífico e Índico, colocando-as na sinonímia de $E$. complanata.

HANSEN, descrevendo Eurythoë brasiliensis, do Rio de Janeiro, atribui à espécie uma carúncula longa, alcançando o $4 .^{\circ}$ anel, brânquias "arbusculiformes" a partir do $2 .^{\circ}$ setígero e cerdas ventrais furcadas, lisas 
(fig. 9). Tais caracteres sugerem a provável identidade entre $E$. brasiliensis e $E$. complanata.

DAY (1967, p. 128) descreve as cerdas de Eury. thoë como "very brittle and hollow containing poison".

Distribuição - A espécie é amplamente distribuída nos mares tropicais, especialmente de ambos os lados das Américas (Hartman, 1968).

Gênero Notopygos Grube 1855

Notopygos crinita Grube 1855

(Fig. 3 e 4)

Notopygos crinita Grube. Ehlers, 1887, p. 24-26, est. 1, fig. 3 ; est. 3 , fig. 5-7. Treadwell, 1939, p. 175-176.

Notopygos crinitus Grube. Kinberg, 1910, p. 33, est. 11, fig. 3 .

5 exemplares completos (AK 36, BAC; AK 50, ACL; AK 53, ACL; AK 59, ACL e AK 61, ACL), o maior com 25 setígeros e medindo $23 \mathrm{~mm}$ de comprimento.

Descrição - Corpo curto e fusiforme, comprimido; segmentos largos, pouco numerosos. Prostômio com uma antena mediana, relativamente longa, duas antenas distais e dois palpos subulados, curtos; 4 olhos sub-iguais, dispostos em trapézio. Carúncula robusta, constituída por uma placa basal multilobada e uma crista longitudinal ligeiramente sinuosa e pregueada; sua extremidade posterior alcançando o $6 .^{\circ}$ setígero (Fig. 3).

Brânquias digitadas a partir do $6 .^{\circ}$ setígero, agrupadas em feixes de $5 \cdot 8$ em cada pé. Notopódios com dois cirros, o interno inserido sôbre uma base cilíndrica longa; neuropódios anteriores com cirro ventral longo, subulado. Cerdas, de um único tipo, bifurcadas, com ramos desiguais. A diferença no comprimento dos ramos é ligeiramente maior nas cerdas neuropodiais.

Discussão - Notopygos crinita é espécie relativamente pouco conhecida. As referências recentes sô. bre ela são esporádicas e, geralmente, imprecisas. As descrições de GRUBE (1855 e 1878) não são ilustradas, o que as torna um tanto ambíguas. Kinberg descreveu exemplares da mesma procedência (Sta. $\overrightarrow{\mathrm{He}}$ lena), atribuindo algumas discrepâncias com a des. crição original, ao seu estado juvenil (1910, p. 33).

EHLERS (1887) descreve 3 exemplares, particularmente robustos, coletados pelo "Blake", no Mar das Antilhas. Sua figura 6 (est. 3) mostra brânquias conspìcuamente palmadas; disposição que não é encontrada nos nossos exemplares.

Quanto a Notopygos megalops McIntosh 1885, descrito das Bermudas (Challenger, p. 17), não nos parece que seja espécie idêntica a $N$. crinita. A dis. posição das brânquias em $N$. megalops (fig. 1) em longa linha transversal é completamente diversa da encontrada em crinita e a carúncula reta e lisa também não pode ser comparada à desta última.

Distribuição $-N$. crinita era conhecida apenas da Ilha de Sta. Helena e do Mar das Antilhas. A ocorrência atual estende a sua distribuição ao Nor. deste brasileiro (Alagoas).

Família PHYLLODOCIDAE Williams 1851

Gênero Anaitides Czerniavsky 1882

Anaitides madeirensis (Langerhans) 1880

(Fig. 5-8)

Phyllodoce (Anaitis) madeirensis Langerhans, 1880, p. 307 , est. 17, fig. 44 .

Phyllodoce (Anaitides) madeirensis Langerhans. Fauvel, 1953, p. 120-121, fig. 59, d-h. Day, 1967, p. 145, fig. 5.2, d-g.

Anaitides madeirensis (Langerhans). Hartman, 1968, p. 231.

? Phyllodoce oculata Ehlers, 1887, p. 135-140, est. 40, fig. 4-6.

5 exemplares, dos quais dois completos (AK 64, ACL e AK 82, D) medindo respectivamente 30 e $35 \mathrm{~mm}$; e 3 fragmentos (AK 04, BAC; AK 12, BAC e AK 102, L-D) com cêrca de 150 setígeros anteriores, medindo, o maior, $98 \mathrm{~mm}$ de comprimento.

Descrição - Corpo longo e comprimido, com segmentos numerosos. Prostômio cordiforme, com 4 pequenas antenas na extremidade e uma reentrância posterior, onde se aloja uma papila occipital globular. Dois olhos muito grandes, próximos à margem pos. terior do prostômio (Fig. 5). Tromba aproximadamente cilíndrica e de secção uniforme. Na base da tromba, de cada lado, 6 fileiras de 11 a 14 papilas triangulares. Bôca guarnecida por um círculo de 17 papilas arredondadas (Fig. 6).

Quatro pares de cirros tentaculares, subulados; o último muito mais longo que os anteriores. Cirros dorsais largos, lanceolados. Cerdas compostas, com a extremidade da haste espinhosa. Cirros ventrais de forma oval, acuminados e ligeiramente mais longos que os lóbulos setígeros (Fig. 7).

Pigídio com dois uritos subulados, curtos.

Côr, no álcool - Variando de castanho claro a branco.

Discussão - Os exemplares desta coleção são semelhantes aos descritos por FAUVEL e por DAY; com a única exceção da fileira mediana de papilas, na tromba; caráter que ambos os autores reconhecem ser variável. 
O espécimem maior alcançaria, se completo, mais que $100 \mathrm{~mm}$ de comprimento, o que não é excepcional, pois Berkeley \& Berkeley (1948, p. 45) mencionam até $15 \mathrm{~cm}$.

Monro (1933, p. 21-22) considerou Phyllodoce oculata Ehlers, como espécie muito próxima de $A$. madeirensis. As figuras de EHLERS (1887, est. 40, fig. 4-6) não são muito explícitas e o autor não menciona a espécie de Langerhans em sua longa discussão; porém, a identidade entre as duas espécies nos parece perfeitamente admissível. Como madeirensis, $P$. oculata tem, de cada lado da tromba, 6 fileiras de papilas ( 9 em cada fileira) e a forma dos cirros parapodiais é muito semelhante em ambas.

Hartman, em seu Catálogo (p. 143 e 163) admitiu uma possível identidade entre $A$. madeirensis e A. erythrophyllus (Schmarda), considerando $P$. oculata Ehlers como sinônimo desta última. Entretanto, em 1961 e 1968 aceita madeirensis como espécie válida.

Macrophyllum benedeni Hansen (1882, p. 2, est. 1, fig. 14-17) do Rio de Janeiro, tem apenas duas antenas e o prostômio muito curto e largo (fig. 15). Seus cirros dorsais de "forme ovale un peu quadrilatère" (fig. 16), a distinguem de madeirensis.

Distribuição - De acôrdo com Rullier (1964, p. 147), Anaitides madeiriensis (Langerhans) é uma das espécies mais cosmopolitas, ocorrendo no Atlântico, desde o Gôlfo da Gasconha até o Antártico.

Gênero Eulalia Savigny 1817

Eulalia cf. bilineata (Johnston) 1840

Eulalia bilineata (Johnston). Fauvel, 1923, p. 162. 163 , fig. 58 , a-e. cerados.

2 exemplares completos (CAN 125, BAC); ma-

Família HESIONIDAE Malmgren 1867

Gênero Hesione Savigny 1818

Hesione picta Fritz Müller 1858

(Fig. 9)

Hesione picta Fritz Müller, 1858, p. 213, est. 6, fig. 3. Hartman, 1951, p. 35.

Hesione margaritae Hansen, 1882, p. 6, est. 1, fig. $18-22$.

Hesione vittata Ehlers, 1887, p. 143-147, est. 41, fig. $2-4$

11 exemplares completos (AK 03, AK 04, AK 14, AK 25, AK 32, AK 48, AK 53, AK 68 (2 exem. plares), AK 95 e CAN 130; em fundos de blocos de algas calcárias); o maior medindo $48 \mathrm{~mm}$ de com. primento.
Descrição - Corpo retilíneo, curto e robusto de seç̧ão elíptica; constituído por cêrca de 16 setígeros. Prostômio pequeno, com duas antenas minúsculas e 4 olhos dispostos em trapézio; sem palpos. Tromba musculosa, inerme; com a extremidade franjada e uma prega triangular, papiliforme, na face dorsal. 8 pares de cirros tentaculares muito longos, não seg. mentados; inseridos sôbre cirróforos conspícuos (Fig. 9).

Parapódios unirremes, cônicos, truncados; cirro dorsal semelhante aos cirros tentaculares, longos e igualmente inseridos sôbre uma base anelada; cirro ventral subulado, ligeiramente mais longo que o pé. $\mathrm{O}$ bordo superior dos parapódios é prolongado por uma papila digitiforme, de comprimento variável.

Cerdas de um único tipo, compostas falcígeras; o artículo longo bi-dentado é provido de uma peça accessória que alcança o dente apical.

Último segmento aqueta; pigídio em mamelão ci. líndrico, com dois uritos longos.

Região dorsal geralmente de côr castanha brilhante sulcada por um intricado desenho de linhas finíssimas amarelo-claro, com manchas transversais branco-amarelado. Dois exemplares têm côr castanha escura pràticamente uniforme, exceto regióes claras sôbre os pés e sôbre a região posterior. Aparentemente, tal variação está relacionada com a idade e desenvolvimento do animal.

Ventre branco-amarelado ou róseo, com uma linha mediana fracamente pigmentada.

A descoloração pela longa permanência no álcool foi intensa em alguns dos exemplares.

Discussão - Hesione picta foi sumàriamente descrita por Fritz Müller e a única figura que ilustra a descrição (fig. 3) é a do prostômio, mostrando apenas a sua forma e a existência de 4 grandes olhos.

A ausência de tentáculos é mencionada no texto (p. 213), juntamente com referências à côr do animal, que Fritz Müller considerou "die schönst ge. färbte der bekannten Anneliden".

Hartman (1951, p. 35), baseando-se em exem. plares do Gôlfo do México (sudoeste da Flórida), considerou $H$. picta Fritz Müller, $H$. vittata Ehlers e H. proctochona Schmarda, como idênticas e atribuiu a prioridade a $H$. picta.

Dispondo além dos exemplares do Akaroa, de farto material coletado no litoral de São Paulo, onde a espécie é comum, pudemos constatar o acêrto da opinião de Hartman. A proximidade do litoral de São Paulo e o de Sta. Catarina, de onde proveio o tipo, aliada à semelhança — senão identidade — das condições biológicas suprem, a nosso vêr, as deficiências da diagnose original.

Consideramos, portanto, como fundamentada a identificação dos espécimens de Hesione desta coleção, como $H$. picta Fritz Müller. 
Distribuição - Atlântico americano, do Gôlfo do México e Antilhas até o sul do Brasil (Sta. Catarina).

Família PILARGIDAE Saint-Joseph 1899

Gênero Synelmis Chamberlin 1919

Diagnose - Parapódios birremes, distintamente separados do ‘orpo; com cirros dorsais e ventrais bem desenvolvi,los. Prostômio conspícuo, com um par de palpos li-articulados e três antenas curtas. Primeiro segmentc aqueta, com um par de cirros lanceolados. Neuropóaios com uma grande cerda acicular reta; cerdas furcadas geralmente presentes. Tegumento liso e sem papilas. Pigídio com dois uritos (adaptada de Pettibone, 1966).

\section{Synelmis albini (Langerhans) 1881}

(Fig. 10-14)

Ancistrosyllis albini Langerhans, 1881, p. 107, fig. 16 , a-e.

Synelmis albini (Langerhans). Pettibone, 1966, p. 191-195, fig. 19.21. Hartman, 1968, p. 393, 5 figs.

Ancistrosyllis rigida Fauvel, 1919, p. 337, fig. 1, a-e. Hartman, 1947, p. 498-501, est. 62, fig. 1-7.

4 exemplares completos (AK 68, ACL (1); AK 95, ACL (2) e AK 103, D (1)), com 88-130 setígeros, o maior com $42 \mathrm{~mm}$ de comprimento e um diâmetro de $1,8 \mathrm{~mm}$.

Descrição - Corpo longo e rígido, com segmentos numerosos, de secção aproximadamente cir. cular. Prostômio trapezoidal, mais longo que largo, com três antenas; dois palpos articulados, com base larga, ovóide e palpostilos globulares, minúsculos; um par de olhos na margem posterior. Tromba musculosa, inerme (evaginada em dois dos exemplares).

Segmento tentacular com um par de cirros subulados, de comprimento aproximadamente igual, desprovido de cerdas. Primeiros setígeros com cirros de tamanho decrescente, até o $4 .^{\circ}$ ou $5 .^{\circ}$ e providos ùnicamente de cerdas capilares limbadas. A partir do $6 .^{\circ}$ setígero os notopódios são dotados de uma grande cerda dorsal, única, acicular, reta (Fig. 12 e 13). Neuropódios com um feixe de cerdas limbadas e, geralmente, duas cerdas furcadas, largas (Fig. 14). As cerdas furcadas são de consistência vítrea, incolores e extremamente frágeis; tais características as tornam inconspicuas, entre as hastes das cerdas lim. badas.

Pigídio cônico, arredondado, com dois uritos mais longos que os cirros parapodiais.

Côr, no álcool - Branco-amarelado e amarelo. -ferrugem, uniforme. Cerdas aciculares amarelas, vítreas.
Discussão - Os 4 exemplares de Synelmis albi. $n i$ estão particularmente bem conservados, permitindo verificar a constância dos caracteres específicos e, conseqüentemente, sua comparação com as descrições de exemplares de várias procedências.

Exceto quanto ao número de manchas oculares, a descrição de $S$. albini elaborada por PEtTibone (1966, p. 192-195), se aplica corretamente aos nos. sos exemplares. A presença de apenas dois olhos, em lugar de 4, foi constatada também por Hartman, em exemplares da Califórnia. Não acreditamos que se deva atribuir maior significação a êsse carácter, que pode ser simples conseqüência da fusão de duas man. chas oculares contíguas; como sugere a forma "semilunar" dos olhos de um dos nossos exemplares.

As demais "discrepâncias" referidas por HART. man (1947, p. 500, na discussão de Ancistrosyllis rigida Fauvel) parecem-nos, também, irrelevantes.

Nos exemplares de $S$. albini desta coleção, os cirros parapodiais são piriformes-subulados ou "fusiformes" como os figurou Hartman para A. rigida; o pigídio porém, é dotado de dois cirros bem separados e relativamente longos. As cerdas furcadas são inseridas na parte superior do feixe, geralmente separadas por duas ou três cerdas limbadas. Observamos esta disposição em cêrca de 20 pés, ligeiramente comprimidos.

Pettibone inclui, na sinonímia de $S$, albini (Langerhans), além de $A$. rigida Fauvel, $S$. simplex Chamberlin, Kynephorus inermis Ehlers, Ancistrosyllis gra. cilis Hessle e A. gorgonensis Monro.

Ancistrosyllis rigida Fauvel foi originalmente des. crita das Ilhas Gambier (Oceania) e A. albini Langerhans, das Ilhas Canárias.

Distribuição - Amplamente distribuída em águas tropicais e sub-tropicais (segundo PEtTibone. 1966). No Atlântico Norte: Ilhas Canárias, Antilhas. Gôlfo do México: Flórida e Dry-Tortugas. Sua ocorrência no Atlântico Sul é inédita.

Família SYLLIDAE Grube 1850

Gênero Typosyllis Langerhans 1879

Typosyllis Langerhans, 1879. Imajima \& Hartman, 1964, p. 118 e 130. Imajima, 1966, p. 265 (diagnose). Hartman, 1968, p. 365.

Diagnose - Corpo longo e de secção sub-cilíndrica, com segmentos numerosos. Prostômio arredondado, com dois pares de olhos conspícuos; palpos triangulares, longos, geralmente fundidos na base; três antenas, a mediana geralmente mais longa; prega occipital estreita ou nula. Antenas, cirros tentacula. res e cirros dorsais multi-articulados, longos e ligeiramente subulados. Faringe com a extremidade orla- 
da por cêrca de 10 papilas e com um dente único, subdistal, robusto. Cerdas tôdas compostas, com artículos longos e curtos, uni ou bi-dentados; exceto nos últimos segmentos, onde ocorrem uma ou duas cerdas simples. Cirro ventral cônico ou digitado. Pigídio com dois uritos articulados (adaptada de ImAJIMA, 1966).

A distinção entre as várias espécies de Typosyllis descritas até o presente, nem sempre é fácil. Diferenças de pigmentação, conspícuas em espécimens vivos, tendem a desaparecer no material fixado. 0 comprimento relativo de apêndices como antenas e cirros parapodiais é muito variável, reduzindo o valor diagnóstico dêsse carácter; o mesmo ocorre com as proporções da faringe e do pró-ventrículo.

O estado de desenvolvimento ("idade") do animal é, muitas vêzes, difícil de apreciar no material fixado, tornando precária a identificação de formas jovens.

Tais circunstâncias se evidenciaram, significativamente, no exame dos exemplares de Typosyllis desta coleção.

\section{Typosyllis prolifera (Krohn) 1852}

Syllis (Typosyllis) prolifera Krohn. Fauvel, 1923, p. 261-262, fig. 97, a-g. 1953, p. 149-150, fig. 74 , a-g. Day, 1967 , p. 248 , fig. 12.3 , g-i.

Typosyllis prolifera (Krohn). Imajima, 1966, p. 292. .294 , fig. 65 , a-n.

2 exemplares completos (AK 21, $\mathrm{H}$ e AK 95, ACL) e 3 fragmentos anteriores, com 36-50 setígeros (AK 95; AK 184, D e AK "arrasto").

Descrição - Corpo longo e muito delgado; os exemplares completos desta coleção, com cêrca de 180 setígeros têm um diâmetro de $1,1 \mathrm{~mm}$. Prostômio largo, com dois pares de olhos e duas manchas oculares minúsculas, no bordo anterior. Palpos triangulares, relativamente curtos, fundidos na base. Antenas mediana com cêrca de 25 segmentos; antenas laterais ligeiramente mais curtas, com 16-20 segmentos. Faringe com um dente sub-distal robusto. Pró-ventrículo ocupando 8-10 segmentos (15. ${ }^{\circ}$ a $24 .^{\circ}$ no exemplar de AK 21).

Parapódios com cirros dorsais multi-articulados, alternativamente curtos (cêrca de 18 segmentos) e longos (cêrca de 35 segmentos); cirro ventral digitado. Cerdas tôdas compostas, com artículo bi-dentado. Cerdas simples, que poderiam ocorrer nos últimos setígeros, não puderam ser evidenciadas; porém, em cada pé dêsses segmentos, um dos acículos é proe. minente, com o aspecto de uma robusta cerda acicular.

Pigídio com dois uritos articulados.
Discussão - Dispondo, nesta coleção, de 9 exemplares de Typosyllis, dos quais 4 completos, nos foi possível constatar que duas espécies estavam representadas.

Os exemplares considerados como Typosyllis prolifera (Krohn) correspondem razoàvelmente bem às descrições da espécie referidas por FAUveL (1923) e IмAJIMA (1966).

Uma possível identidade entre esta espécie e Ty. posyllis variegata Grube é examinada na discussão desta última, abaixo.

Distribuição - T. prolifera, originalmente conhecida apenas do Mediterrâneo e do Atlântico tem uma área de distribuição muito ampla, abrangendo também o f́ndico e o Pacífico (DAY, 1967).

Os espécimens atuais provém da costa dos Es. tados de Alagoas e Sergipe.

\section{Typosyllis variegata (Grube) 1860}

Syllis (Typosyllis) variegata Grube. Fauvel, 1923, p. 262, fig. 97 , h-n. 1953, p. 148-149, fig. 74 , h-n. Day, 1967, p. 248, fig. 12.3, j-l.

Typosyllis variegata (Grube). Imajima \& Hartman, 1964 , p. $137-138$, est. 34 , fig. a-i. Imajima, 1966, p. 292.

1 exemplar completo (AK 24, BAC) com cêrca de 120 setígeros medindo $28 \mathrm{~mm}$ de comprimento e 4 fragmentos anteriores, com cêrca de 40 setígeros (AK 17, BAC; AK 32, BAC; AK 64, BAC e AK 184, ACL).

Descrição - Corpo longo e delgado, de secção elíptica. Prostômio largo, com dois pares de olhos conspícuos; palpos longos, triangulares, ligeiramente divergentes, fundidos apenas na base. Antenas com anelação fortemente marcada, a mediana com 30-36 segmentos e as laterais, com 18-25. Faringe com a extremidade orlada por $10-11$ papilas carnosas e com um dente interno, dorsal. Pró-ventrículo ocupando 15-16 segmentos $\left(20 .^{\circ}-36 .^{\circ}\right.$ no exemplar de AK 17).

Parapódios com cirros dorsais multi-articulados, alternativamente curtos e longos (cêrca de 25 e cêrca de 40 segmentos) e cirros ventrais digitados. Cerdas tôdas compostas, com artículos bi-dentados.

As cerdas da parte superior dos feixes e a maioria das cerdas dos setígeros medianos têm artículos proporcionalmente muito mais curtos. As cerdas simples, que poderiam ocorrer nos segmentos da região posterior, não foram encontradas no único exemplar completo. Acículos robustos, em número de 2 a 5 em cada pé; nos segmentos da região mediana e posterior, a extremidade de um ou mais acículos emerge entre as cerdas. Pigídio com dois uritos articulados, longos. 
Discussão - Apenas um dos fragmentos, o da estação n. ${ }^{\circ} 17$ exibe a pigmentação tida como característica para a espécie; é um exemplar robusto, com um diâmetro de $2,1 \mathrm{~mm}$, à altura do $36 .^{\circ}$ setígero (último do fragmento) e tem a região dorsal ornada por faixas transversais de côr castanha escura.

Nos demais, o dorso é irregular e indistintamente pigmentado.

A forma do prostômio e as características das antenas e cirros coincidem com as descritas por IMAJiмA (1966, p. 292). As características da faringe, clarqmente visiveis em dois exemplares, coincidem também com as referidas pelo autor.

Quando às cerdas compostas, constatamos uma variação considerável nas proporções dos dentes dis. tais.

É possivel que tal variação esteja relacionada com o estágio de desenvolvimento do animal. Cerdas com artículos fortemente bi-dentados, como a de alguns de nossos exemplares, ocorrem em $T$. hyalina (Grube), espécie que DAY (1967, p. 246) admite ser, possivelmente, um estágio jovem de $T$. variegata.

T. variegata (Grube) e T. prolifera (Krohn) têm muitos caracteres em comum, a distinção entre ambas baseando-se essencialmente em diferenças de pigmentação e no comprimento do pró-ventrículo. De acôrdo com IмаJima (p. 294) "T. prolifera may be distinguished from $T$. variegata as follows: (1) the dorsum of the first is purplish brown and has no color markings, instead of irregular, light purple transverse bands, and (2) the first has a proventriculus extending through 5 to 6 , instead of 10 to 13 segments".

Consideramos que a eficiência de tal critério é condicionada, até certo ponto, pelo número de exemplares da mesma procedência, disponíveis para comparação.

O comprimento relativo do pró-ventrículo é, a nosso vêr, um critério objetivo; porém, a pigmentação, em exemplares fixados, pode variar de forma desconcertante, mesmo quando a uniformidade dos métodos de preservação haja sido mantida.

Em nossos exemplares, tanto de prolifera quanto de variegata, o comprimento do pró-ventrículo é maior que o mencionado nas descrições respectivas, de Imajima; porém a relação é pràticamente a mesma, abran. gendo 8-10 segmentos na primeira e 15-16 na segunda.

FAuvel (1953, p. 150) observa que variegata e prolifera são, muito verossimilmente, variedades de uma única espécie. Ainda assim, baseados na opinião de Imajima, consideramos ambas como espécies válidas.

Distribuição - $T$. variegata é considerada espécie cosmopolita, com ampla distribuição no Atlântico europeu, Mediterrâneo, áreas do Indo-Pacífico (Califórnia, Mar de Bering, Mar Amarelo e Jepão; Ima. JIMA, 1966). Os exemplares desta coleção provém da costa de Alagoas e de Sergipe.

Família NEREIDAE Johnston 1865

Gênero Nereis Linneu 1758

Nereis sp.

(Fig. 15-20)

1 exemplar completo (AK 155, BAC), medindo $28 \mathrm{~mm}$ de comprimento e 8 fragmentos anteriores (AK 06, BAC; AK 21, H; AK 48, BAC; AK 53, ACL (2); AK 56, BAC; AK 74, ACL; AK 102, L-D e CAN 121, H-ACL).

A descrição se baseia no exemplar completo, que é também o melhor conservado.

Os 8 exemplares fragmentários são constituídos por 30-48 setígeros anteriores e assemelham-se, com pequenas variações, ao espécimem completo.

A dissecção da tromba, invaginada em todos, foi prejudicada pela fragilidade do material precàriamente fixado. Em conseqüência, o número de paragnatas das áreas laterais não foi constatado com exatidão.

Descrição - Palpos e antenas característicos do gênero Nereis. Tromba com mandíbulas largas e côncavas, com dentes bem recortados; paragnatas côncavas, fortemente quitinizadas: $\mathrm{I}=3$, em linha longitudinal; II = grupo em faixa obliqua; III = grupo ca. $10 ; \mathrm{IV}=$ grupo em faixa oblíqua $; \mathrm{V}=0 ; \mathrm{VI}=$ grupo ca. $12 ;$ VII + VIII $=5$, grandes, em linha (Fig. 15 e 16).

Notopódios dos segmentos anteriores com dois lóbulos e um longo cirro dorsal; notopódios dos setígeros posteriores com 1.2 cerdas espinígeras e uma cerda falcígera homogonfa, robusta, com o artículo serrilhado e aproximadamente reto (Fig. 17 a 20).

Discussão - As características do espécimem completo assemelham-se às de Nereis trifasciata Grube, como descrita por FAUVEL (1953, p. 183) e DAY (1967, p. 312). Quanto aos demais, a falta dos segmentos posteriores impede que se verifique neles a existência de cerdas notopodiais falcigeras homogon. fas, carácter decisivo na distinção entre esta espécie e Nereis (Neanthes) unifasciata Willey.

As duas espécies ocorrem nas mesmas áreas (tanto no f́ndico, quanto na África do Sul) e têm parag. natas distribuídas de forma pràticamente idêntica (vide Day, fig. 14.6, l-m e fig. $14.7 \mathrm{n}-\mathrm{v}$ ). FAUVEL (1953) as considerou como "closely allied species".

Gênero Pseudonereis Kinberg 1866

Pseudonereis sp. 
1 exemplar incompleto (AK 45, BAC), fêmea, epítoca.

Família NEPHTYIDAE Grube 1850

Gênero Nephtys Cuvier 1817

Nephtys squamosa Ehlers 1887

(Fig. 27-31)

Nephthys squamosa Ehlers, 1887, p. 128-131, est. 37, fig. 7-10. Hartman, 1940 , p. 237-238, est. 4l, fig. 98-99.

Nephtys squamosa Ehlers. Pettibone, 1963, p. 194. -195, fig. 47 e.

3 exemplares completos e 9 fragmentos anteriores (AK 19, A; AK 69, A; AK 71, ACL; AK 84, A (4 ex.) ; AK 85, BAC; AK 89, A (2 ex.) e AK 152, A-L (1 ex.)) ; o maior exemplar completo, com 127 setígeros, medindo $62 \mathrm{~mm}$ de comprimento.

Descrição - Corpo longo e robusto, ligeiramente comprimido. Prostômio trapezoidal; com a margem anterior espatulada e com faixas longitudinais translúcidas. Tromba com a base lisa e a parte distal com 5-6 séries transversais de papilas subuladas (Fig. 27); bôca orlada por 20 pares de papilas piriformes (Fig. 28).

Parapódios com lamelas dorsais hipertrofiadas e rebatidas sôbre o pé seguinte, com o aspecto de escamas (Fig. 29 e 30); lamelas ventrais largas, porém menos conspícuas. Brânquias (cirros interramais) bem desenvolvidas a partir do $2 .^{\circ}$ setígero; enroladas "para fora" e com um lóbulo basal longo. Lóbulos post-setais foliáceos, cordiformes ou lanceolados, muito grandes.

Feixes dorsais e ventrais com cerdas em fita, muito longas e cerdas barradas, estas menos numerosas e mais curtas (Fig. 31). Cerdas liriformes não foram encontradas nos exemplares examinados.

Discussão - Nephtys squamosa Ehlers é conspìcuamente caracterizada pelas expansões laminadas dos parapódios, que recobrem o espaço entre dois pés sucessivos, simulando verdadeiras escamas. Este aspecto é mais aparente nos segmentos medianos, nos quais cada lamela é mais larga e mais longa, alcançando a origem da seguinte e ocultando parte das cerdas.

Os lóbulos post-setais prolongados em forma de lígula, envolvendo parcialmente a base das cerdas, sâo também característicos.

Em nossos exemplares, a forma dêsses lóbulos aproxima-se mais da figurada por EHLERS (est. 37, fig. 7). As figuras de Hartman (1940, est. 41, fig. 98 e 99) são essencialmente semelhantes às de Ehlers, diferindo apenas quanto ao comprimento dos lóbulos post-setais e à presença de um pequeno lóbulo présetal digitiforme, que não ocorre em nosso material.
Distribuição - Ambos os lados da América tropical e Marrocos (Pettibone, 1963). Costa nordeste do Brasil (Alagoas e Sergipe).

\section{Família GLYCERIDAE Grube 1850 \\ Gênero Glycera Savigny 1818 \\ Glycera americana Leidy 1855}

(Fig. 26)

Glycera americana Leidy. Hartman, 1950, p. 73-75. 1968, p. 613. Pettibone, 1963, p. 213-215, fig. 54 , a-e. Wesenberg-Lund, 1962, p. 100, fig. 44$-46$.

2 exemplares incompletos (AK 02, ACL e AK 79, ACL) com cêrca de 150 e 85 setígeros anteriores. medindo respectivamente 110 e $30 \mathrm{~mm}$ de compri. mento.

Descrição - Corpo longo, de secção cilíndrica, com o maior diâmetro no têrço anterior. Prostômio longo, com base larga, constituído por 10 a 12 anéis pouco marcados; antenas curtas, relativamente gros. sas. Tromba claviforme, robusta, com a superfície densamente recoberta por papilas; estas são inteira. mente lisas, diferindo entre si apenas quanto à forma: as mais numerosas são altas e delgadas, as outras, globulosas ou piriformes. Os dentes, na extremidade da tromba evaginada, são fortes e largos, com uma peça accessória igualmente larga e de forma peculiar (Fig. 26).

Parapódios com dois lóbulos pré-setais triangulares, longos e estreitos e dois lóbulos post-setais semelhantes aos pré-setais, porém mais curtos. Cirro dorsal piriforme, bem separado dos lóbulos setais; cirro ventral triangular, largo. Brânquias digitadas, retrácteis, emergindo da face posterior do pé, junto à sua linha de inserção. Nos dois exemplares examinados, a primeira brânquia aparece no $18 .^{\circ}$ pé, com a forma de um pequeno cirro sacular, transparente. $\mathrm{O}$ número e forma dos ramos branquiais varia extre. mamente com o seu grau de expansão; parcialmente evaginada a brânquia aparece como a extremidade de um ou vários dedos de luva; em plena expansão, nos segmentos posteriores, é arborescente; com um tronco largo multi-ramificado, conservando ainda o carácter sacular.

Côr, no álcool - Amarelo ferrugem, escura, sem pigmentação localizada.

Discussão - Glycera americana Leidy, descrita originalmente da costa leste dos Estados Unidos (Rhode Island e New Jersey) caracteriza-se pela forma dos lóbulos post-setais, duplos, longos e acuminados e pelas papilas da tromba, desprovidas de qualquer escultura.

Hartman, 1950 (p. 69) distingue G. americana de $G$. longissima Arwidsson baseando-se apenas no 
comprimento dos lóbulos post-setais que, nesta úl'ima espécie, seriam mais curtos que os pré-setais.

Wesenberg-Lund (1962, p. 100-102, fig. 44-46) caracteriza corretamente as duas espécies, dan lo excelentes desenhos dos parapódios. Curiosam/nte, a importância do comprimento relativo dos lób ulos setais não é confirmada, pois as 3 figuras de Wesenberg-Lund mostram lóbulos post-setais mu to mais curtos que os pré-setais, ainda que o texto esj ecifique: "All the four parapodial lobes are rather abruptly pointed and nearly of the same length...'

A fig. 47, de G. longissima é, entret ınto, perfeitamente convincente, com o lóbulo post- retal arredondado e apenas sub-dividido e uma brinquia em forma de tufo compacto. Eventualmente, $\mathbf{i}$. longissi. ma poderá ser considerada a forma mą̧elânica de G. americana Leidy.

Hartman examinou os tipos de Glycer: jucunda e G. laevis, descritas por KINBERG (1866, p. 245-246 e 1910 , p. 58 , est. 21 , fig. 5 e 6 ) da costa rasileira e concluiu que estas são espécies idênticas a $G$. americana $(1948$, p. 99-100).

Quanto a $G$. edentata Hansen, do Ric de Janeiro, colocada por Hartman (1950, p. 74), com uma interrogação, na sinonímia de $G$. americ $n a$, foi a nosso vêr, insuficientemente caracterizada por HaxSEN (1882, p. 17, est. 5, fig. 16-18).

Pettibone (1963, p. 215) estende a distribuição da espécie, no Atlântico Sul, até a Argeı tina; baseando-se, provàvelmente, na referência de RıoJA (1944, p. 128). Porém, examinando as tiguras do autor (p. 126, fig. 35 a 38) somos inclinaios a concordar com Hartman (1950, p. 74) que acredita ter Rioja identificado seus exemplares errônear ente, como G. americana. As papilas da tromba, sulcadas por pregas paralelas (fig. 39) e a arquitetı ra do pé (fig. 35) com lóbulos post-setais arredond idos, sugerem uma espécie diferente.

Distribuição - G. americana ocorre de ambos os lados das Américas; no Atlântico é conhecida desde New England até o Brasil; no Pacífico, do Canadá até o Peru. Foi referida também (por AugeNer) da Nova Zelândia e da Austrália (Hartman, 1950).

Os exemplares desta coleção prové n da c.sta do Estado de Alagoas.

\section{Glycera longipinnis Grube 1878}

(Fig. 21-25)

Glycera longipinnis Grube, 1878, p. 182, est. 8, fig. 9. Fauvel, 1932, p. 125, est. 4, fig. 11-14. 1953, p. 291, fig. 148, a-d. Day, 1967, p. 356, fig. 16.1, a-f.
7 exemplares: AK 08, AK 82, AK 86, AK 94, AK 103, AK 104 e CAN 137; em fundos detríticos e de areia e lôdo.

Descrição - Espécie relativamente pequena, o maior exemplar desta coleção medindo apenas $68 \mathrm{~mm}$ de comprimento. Corpo robusto, afinando ràpidamente na região posterior. Prostômio longo, acuminado, com 11.12 anéis. Tromba claviforme, curta; densamente recoberta por papilas simples, não sulcadas, de dois tipos. As papilas mais numerosas são subuladas e estreitas; as demais, piriformes ou ovaladas (Fig. 22). Ao longo do eixo de cada papila correm duas fibras refringentes, particularmente conspícuas nas papilas fragmentadas. Maxilas robustas; com duas peças accessórias de comprimento igual e articuladas em "V" (Fig. 23).

Parapódios com dois lóbulos pré-setais lanceolados, muito longos e um único lóbulo post-setal curto e arredondado; cirro dorsal bem desenvolvido, piriforme; cirro ventral largo, triangular (Fig. 24). Brânquias a partir do $34 .^{\circ}$ setígero, em forma de cirro, muito mais longas e mais largas que os lóbulos pré-setais; emergindo do bordo superior do pé (Fig. 25). Cerdas dorsais capilares, robustas; cerdas ventrais compostas, com haste homogonfa e artículo longo, com o bordo finamente serrilhado. As cerdas são pouco numerosas, um parapódio mediano possuindo aproximadamente 6-7 cerdas simples e 6-8 compostas.

Cór, no álcool - Branco leitoso; brânquias ligeiramente pigmentadas.

Discussão - Excetuada a presença de papilas de dois tipos, na tromba dos exemplares do "Akaroa", êstes correspondem exatamente à descrição de Glycera longipinnis. As diagnoses de GRUBE (1878) e de Fauver. (1932) mencionam apenas um tipo de papila; entretanto, DAY (1967, fig. 16.1, d) figura os dois tipos também encontrados em nossos exemplares. É admissível que as papilas "piriformes" tenham existido, porém inconspícuas, nos espécimens de Grube e Fauvel. Considerando que as diferenças entre os dois tipos de papilas se limitem exclusivamente à forma, mais ou menos dilatada, não atribuímos ao carácter, maior importância.

A conformação dos pés medianos de $G$. longipinnis, com a grande brânquia simulando um cirro dorsal hipertrofiado, é extremamente peculiar. Em tôdas as outras espécies de Glycera dotadas de uma brânquia simples, esta tem uma conformação inconfundivel; porém, no caso de longipinnis, o caráter de brânquia é muito pouco evidente. GRUBE parece haver reconhecido a singularidade dessa brânquia, à qual se refere como "Das Organ, welches ich als kieme bezeichnet habe..." e a caracteriza minuciosamente (p. 183).

Os lóbulos pré-setais, em número de dois, muito longos e de forma lanceolada, associados a um ló- 
bulo post-setal único, indiviso, são características para a espécie.

Aparentemente, pequena importância tem sido atribuída aos acículos, pois não encontramos referências explícitas à sua posição nos lóbulos parapodiais. Em nossos exemplares, os dois acículos penetram profundamente nos lóbulos pré-setais respectivos. As figuras de FAUvel e de DAY não nos parecem concludentes.

G. longipinnis tem afinidades com G. papillosa Grube, $G$. lancadivae Schmarda e $G$. tesselata Grube, espécies cuja tromba é guarnecida do mesmo tipo de papilas. Porém, distingue-se delas pela presença de brânquias. G. tesselata, que ocorre no Atlântico, difere, ainda, pelos parapódios com dois lóbulos postsetais. G. convoluta Keferstein tem brânquias de um tipo semelhante, mas difere pelos lóbulos post-setais duplos e pelas papilas da tromba com a extremidade alada ("with a distal flange shaped like a finger-nail" DAY, p. 360).

Concluindo: $G$. longipinnis Grube se distingue das espécies congêneres pelo conjunto dos seguintes caracteres: forma peculiar das brânquias, simples, longas e largas; lóbulo post-setal único; papilas da tromba, lisas, desprovidas de pregas e de expansões terminais; maxilar com duas peças accessórias longas e bem separadas.

Distribuição - Philipinas, Baía de Bengala, Gôlfo do Iran (FAuvel, 1932); África do Sul (DAY, 1967). Nordeste do Brasil (Alagoas e Sergipe).

\section{Família ONUPHIDAE Kinberg 1865}

Gênero Diopatra Audouin \& Milne Edwards 1833 Diopatra cf. cuprea (Bosc) 1802

Diopatra cuprea (Bosc). Hartman, 1944 a, p. 54, est. 1, fig. 9-14. Pettibone, 1963, p. 250-254, fig. 66 .

Diopatra cuprea cuprea Day, 1967, p. 417, fig. 17.12, a-d.

4 exemplares incompletos (AK 10, L; AK 91, BAC; AK 132, ACL e AK 163, L) com cêrca de 50 setígeros anteriores.

Diagnose (adaptada de Pettibone, 1963) - Espécie robusta, alcançando até $300 \mathrm{~mm}$ de comprimento. Tegumento geralmente com cutícula espêssa, iridescente. Prostômio sub-oval, com antenas frontais cônicas, curtas e 5 antenas occipitais com ceratóforos anelados (cêrca de 8-10 anéis). Um par de órgãos sensoriais na base das antenas laterais internas; um par de cirros tentaculares, no bordo anterior do $1 .{ }^{\circ}$ segmento, que é ápodo. Ventralmente, um par de grandes palpos globulares.
Cirros ventrais dos 4.5 primeiros setígeros; cônicos, curtos; passando a uma prega em forma de almofada, a partir do $6 .^{\circ}$ setígero.

Brânquias a partir do $4 .^{\circ}$ ou $5 .^{\circ}$ setígero, espiraladas, com uma base curta e mais ou menos anelada; cêrca de 30 pares de brânquias, dos quais os da região anterior são os maiores.

Segmentos branquais com um lóbulo central, cônico, cercado por cerdas de 3 tipos: um feixe superior de cerdas pectinadas, com cêrca de 20 dentes muito finos; cerdas limbadas e dois grossos ganchos sub-aciculares, curtos, bi-dentados.

Os primeiros setígeros (desprovidos de brânquias) têm ùnicamente cerdas (ganchos) bi-dentados, com o dente distal formando um ângulo obtuso com o corpo da cerda; o dente accessório é aproximadamente paralelo ao principal.

Segmentos da região posterior com 4-5 acículos, cujas extremidades afiladas emergem do lóbulo setígero.

Peças bucais de côr clara com a margem denteada escura; max. II com 8-12 dentes; max. III (ímpar) com 8-10; max. IV, curva, com 4.7 e 8-10; max. V em placa rudimentar.

Os exemplares desta espécie, coletados pelo AKAROA, são pequenos e estão parcialmente macerados. Entretanto, correspondem razoàvelmente bem às descrições de Hartman e Pettibone.

Os fragmentos de tubos, presumivelmente da parte superior, são densamente recobertos com fragmentos calcários e detríticos orgânicos.

A disposição das papilas das antenas é a característica para a espécie, com duas ou três fileiras de papilas minúsculas intercalada entre fileiras de papilas grandes, arredondadas. Também a forma dos ganchos dos primeiros setígeros, com um único dente accessório e o dente principal oblíquo, coincide com a figurada por HaRTMan (est. 1, fig. 14).

Discussão - A caracterização correta de D. cuprea nos parece difícil e, no caso atual, essa circunstância é a gravada por serem os nossos exem. plares, pequenos e fragmentados.

Como outras espécies, muito próximas, estão representadas nesta coleção, atribuímos particular im. portância às características dos tubos, das antenas e das cerdas dos primeiros setígeros, visando a melhor identificação de cada uma delas.

Pettibone (1963, p. 252-255) menciona dados interessantes sôbre a biologia de $D$. cuprea, descrevendo minuciosamente as peculiaridades do tubo. A autora evidencia o fato de que o material estranho de que êstes são incrustados, varia com o habitat e que, nas praias lodosas o animal incorpora ao tubo fragmentos vegetais. 
Parece-nos, portanto, justificável atribuir às características do tubo, importância decisiva na distinção entre cuprea e algumas espécies próximas. A raridade das informaçôes sôbre os tubos das espécies coletadas e descritas por autores contemporâneos torna, entretanto, difícil comprovar o acêrto dessa opinião.

D. variegata Hansen (1882, p. 9, est. 3, fig. 4-14), do Rio de Janeiro, é considerada sinônimo de D. cuprea (HaRtMan, 1959, p. 300).

D. brasiliensis Kinberg, também do Rio de Janeiro, tem ganchos tri-dentados nos setígeros anteriores, caráter que a distingue de cuprea. HaRtman (1944a, p. 53) considera as duas espécies distintas.

Distribuição - Na costa americana, D. cuprea é conhecida desde Massachusetts até o Brasil (HARTman, 1944a; Pettibone, 1963).

\section{Diopatra cf. ornata Moore 1911}

Diopatra ornata Moore, 1911, p. 273-277, est. 18, fig. 77-85. Hartman, 1944a, p. 55-56, est. 1 fig. 15-20. 1968, p. 659, 5 figs. Berkeley \& Berkeley, 1948, p. 94-95, fig. 142-143.

3 exemplares incompletos (AK 01, L (2) e AK 172, L) com 35.60 setígeros anteriores.

Diagnose (adaptada de Berkeley \& Berkeley, 1948) - Espécie robusta, alcançando $250 \mathrm{~mm}$ de comprimento. Prostômio quase inteiramente ocupado, na face dorsal, pelos ceratóforos das antenas occipitais. Antenas frontais subuladas, relativamente longas. Antenas occipitais longas; as laterais internas alcançando o $15 .^{\circ}$ ou $16 .^{\circ}$ setígero, quando dobradas para trás.

Primeiros 4 setígeros com cirros dorsais longos e cirros ventrais subulados, relativamente curtos; no $5 .^{\circ}$ setígero o cirro ventral é muito mais curto e arredondado e, nos subseqüentes, é reduzido a uma prega alta, em forma de almofada.

Brânquias a partir do $5 .^{\circ}$ ou $6 .^{\circ}$ setígero, até o $50 .^{\circ}-80 .^{\circ}$; os primeiros pares são os melhores desen. volvidos.

Cerdas (ganchos) bi-dentados dos primeiros setígeros com o dente distal fortemente recurvado, formando um ângulo aproximadamente reto com o corpo da cerda; dente accessório robusto, emergindo em posição normal à haste da cerda. Cerdas pectinadas com cêrca de 20 dentes muito finos. Ganchos bi-dentados, encapuzados, robustos, do $6 .^{\circ}$ ao $300^{\circ}$ setígero.

Tubos com uma base pergaminhosa, usualmente cobertos grosseiramente com fragmentos minerais ou de conchas ou de qualquer material accessível, de forma que sua aparência pode ser muito variável.
Os exemplares desta coleção, considerados como $D$. ornata, possuem um número elevado de brânquias e ganchos dos setígeros anteriores com o dente distal fortemente recurvado.

O fragmento maior, com 60 setígeros, tem brânquias bem desenvolvidas, ainda com 6 filamentos no último segmento. Tais caracteres coincidem com os da espécie de Moore e apenas as condições relativamente precárias dos espécimens justifica a reserva com que foram identificados.

Os fragmentos de tubo, dois dêles contendo animais, são recobertos por uma camada de argila entremeada com detritos orgânicos.

Discussão - D. ornata aproxima-se, quanto ao número de brânquias e à forma dos ganchos dos setígeros anteriores, a D. spiribranchis Augener. Distingue-se desta pelo tubo de arquitetura diferente e por suas antenas, que são muito mais curtas e recobertas por papilas predominantemente minúsculas, em fileiras numerosas e irregulares.

Hartman (1944a, p. 56) considera que D. ornata se assemelha a D. cuprea quanto a vários caracteres e as distingue, na chave de classificação, por diferenças na forma e disposição das papilas das antenas e na forma dos ganchos bi-dentados dos setígeros anteriores.

A existência de cerdas (ganchos) com as formas descritas e figuradas por Hartman (est. 1, fig. $11, D$. cuprea e fig. 15, D. ornata) é indubitável, tendo sido constatada também nos espécimens desta coleção. Porém, sua especificidade não pôde ser compravada por nós. As formas típicas, extremas, são excepcionais, predominando as formas "de transição", geralmente inócuas.

Distribuição - D. ornata era conhecida exclusivamente da costa do Pacífico; a ocorrência atual estenderia sua área de distribuição até o Nordeste do Brasil (Alagoas).

\section{Diopatra spiribranchis Augener 1906}

(Fig. 32-34)

Diopatra spiribranchis Augener, 1906, p. 145-148, est. 5, fig. 88-96.

? Diopatra longicornis Kinberg, 1865. 1910, p. 3ิȳ, est. 14, fig. 6 .

4 exemplares incompletos (AK 170, L e AK 171, L), o maior com cêrca de 150 setígeros anteriores, medindo $118 \mathrm{~mm}$ de comprimento, com um diâmetro de cêrca de 3 mm. Tubos vazios: AK 174 e AK 179.

Descrição - Corpo longo, pouco comprimido. Prostômio com antenas frontais piriformes-subuladas; antenas occipitais muito longas, com 3-4 faixas trans. versais pigmentadas, inseridas sôbre ceratóforos ane- 
lados, ligeiramente cônicos. As antenas laterais internas, quando dobradas para trás alcançam o $25^{\circ}$ setígero (Fig. 32).

Papilas das antenas de um único tipo, dispostas em séries longitudinais simétricas (Fig. 34).

Junto à base das antenas internas, duas grandes papilas hemisféricas (olhos?). Cirros nucais longos, afilados.

Parapódios anteriores grandes, com cirros dorsais e ventrais longos, acuminados e um lóbulo post. -setal cujo comprimento iguala o das cerdas.

A partir do $6 .^{\circ}$ setígero o cirro ventral é subs. tituído por uma simples saliência em forma de almofada retangular.

Brânquias a partir do $4 .^{\circ}$ setígero; o primeiro par já plenamente desenvolvido, com pínulas curtas, dispostas em espiral, em tôrno de uma haste longa. As brânquias dos 50 primeiros setígeros são aproximadamente iguais entre si; nos segmentos posteriores seu comprimento e o número de pínulas decresce gradualmente. N'um dos exemplares (incompleto) com 86 setígeros, o último segmento tem brânquia reduzida a um filamento único, mais curto que o cirro dorsal.

Peças bucais de côr castanho claro; maxilas II-IV com dentes pequenos, bem recortados; maxila II com 10.11 dentes; peça ímpar com 9 dentes.

Tubos - Muito grossos, com a parede espêssa; formados por lama compacta e revestidos internamente por uma membrana elástica e lisa. $\mathrm{O}$ diấmetro externo alcança cêrca de $10 \mathrm{~mm}$; a côr é pardo-amarelada (decorrendo, òbviamente, da côr da lama, pois os tubos de $D$. tridentata da mesma região são, igualmente amarelados).

Discussão - Preferimos, contràriamente à opinião de vários autores, considerar como válida a es. pécie de Augener.

Pudemos estudar 3 exemplares perfeitamente conservados e os respectivos tubos, verificando a constância de caracteres que nos parecem peculiares à espécie e suficientes para distinguí-la.

A nosso vêr, Diopatra spiribranchis Augener, não deve ser incluída na sinonímia de D. cuprea (Bosc).

Justificamos a nossa opinião, com a profunda diferença na estrutura dos tubos e nas características das antenas.

Os tubos, particularmente frágeis e revestidos exclusivamente por lama, diferem muito dos comumente descritos para $D$. cuprea, e que têm a parte superior densamente recoberta por fragmentos de conchas e detritos.

Quanto às antenas, são em spiribranchis, muito mais longas e mais delgadas que em cuprea e a dis- posição das papilas é diferente. Acreditamos, ainda, que sua anatomia microscópica seja peculiar.

A descrição e as figuras de Augener (1906) são claras e explícitas, correspondendo estreitamente às características dos nossos exemplares.

Entretanto, a discussão do autor (1918, p. 353-355) justificando a colocação da espécie na sinonímia de $D$. cuprea, é prolixa e inconcludente.

É possível que D. spiribranchis Augener constitua, na realidade, uma sub-espécie de $D$. cuprea, peculiar à região caraíbica; parece-nos, entretanto, essencial distinguí-la da espécie típica.

Distribuição - D. spiribranchis foi descrito do material coletado pelo "Blake" ao largo da Ilha de Trinidad $\left(11^{\circ} 5^{\prime} \mathrm{N}, 61^{\circ} 17^{\prime} \mathrm{W}\right)$ e não encontramos outras referências, sob o nome original. Os exemplares desta coleção foram coletados na costa do Estado de Ala. goas.

\section{Diopatra tridentata Hartman 1944}

Diopatra tridentata Hartman, 1944a, p. 61-63, est. 2, fig. 37-43; est. 17, fig. 335-336. 1968, p. 663 , 4 figs.

? Diopatra brasiliensis Kinberg, 1910, p. 38-39, est. 13, fig. 4. non Hansen, 1881.

3 exemplares incompletos, em seus tubos (AK 78, ACL e AK 94, A+L) com cêrca de 60 setígeros anteriores medindo $38.40 \mathrm{~mm}$ de comprimento e cêr. ca de $2,5 \mathrm{~mm}$ de maior diâmetro.

Descrição - Corpo longo e comprimido, com segmentos muito numerosos. Prostômio com antenas frontais afiladas, curtas; antenas occipitais longas e subuladas, com ceratóforos anelados e recobertas por papilas minúsculas, dispersas.

Parapódios dos 4 primeiros setígeros muito maiores que os seguintes; com grandes cirros dorsais $\mathrm{e}$ ventrais e um lóbulo post-setal triangular, mais longo que as cerdas. Após o $4 .^{\circ}$ setígero, o cirro ventral é substituído por uma simples elevação em forma de almofada. Brânquias, a partir do $4 .^{\circ}$ ou $5 .^{\circ}$ setígero; a primeira já plenamente desenvolvida, com pínulas muito numerosas, dispostas em espiral. Os 20 primeiros pares de brânquias são semelhantes entre si, o comprimento e o número de pínulas decrescendo ràpidamente após o $25 .^{\circ}$ a $30 .^{\circ}$ setígero; em nossos exemplares, subsistem, no $32 .^{\circ}$ pé, apenas 1-3 fios consideràvelmente menores que o cirro dorsal. Os segmentos medianos, até o $60 .^{\circ}$, são desprovidos de brânquias.

Ganchos sub-aciculares dos 4 primeiros setígeros, conspìcuamente tri-dentados; o dente distal muito mais longo que os demais. Nos segmentos sub- 
seqüentes êstes ganchos são substituídos por cerdas limbadas, geniculadas. A partir do $10 .^{\circ}-12 .^{\circ}$ setígero, aparecem ganchos sub-aciculares bi-dentados, robustos, amarelo-dourados, juntamente com cerdas limbadas aproximadamente retas e cerdas pectinadas, com dentes muito finos e numerosos.

Peças bucais de côr clara, com uma linha escura na margem interna. Maxila II-IV com dentes minúsculos, bem recortados; a maxila II, ligeiramente assimétrica, tem cêrca de 10 dentes.

Os fragmentos de tubos são constituídos pela parte anterior, com cêrca de $40 \mathrm{~mm}$ de comprimento e 3.5 $.4 \mathrm{~mm}$ de diâmetro. São cilíndricos e com a superfície anelada, formados por camadas concêntricas de lôdo fino e compacto, revestidos interna e externamente por uma membrana resistente.

Discussão - Diopatra tridentata Hartman, assemelha-se quanto à presença de ganchos tri-dentados nos primeiros setígeros, a D. brasiliensis Kinberg, do Rio de Janeiro.

Hartman, ao descrever tridentata, reconhece tal semelhança, porém considera que a descrição de Kinberg é insuficiente para uma comparação acurada.

Concordamos com a opinião dessa autora e preferimos atribuir aos exemplares desta coleção, o nome da espécie melhor descrita.

Quanto à sugestão de Augener (referida por HARTMAN, à p. 53) admitindo uma possível identidade entre esta espécie e Diopatra cuprea (Bosc) parece-nos inteiramente destituída de fundamento.

$\hat{E}$ de se lamentar que Kinberg não haja examinado e descrito o tubo de $D$. brasiliensis, pois acreditamos que as características singulares do tubo de D. tridentata constituam critério decisivo para a caracterização da espécie.

Distribuição - D. tridentata, descrita da Califórnia, era conhecida da costa ocidental do México e do Mar das Antilhas (Hartman, 1968). Seus tubos são comuns no material proveniente de dragagens costeiras no litoral sul do Brasil (obs. não publicada); os exemplares aqui descritos provém da costa do Es. tado de Alagoas.

Gênero Onuphis Audouin \& Milne Edwards 1833 Onuphis litoralis Monro 1933

(Fig. 35-43)

Onuphis litoralis Monro, 1933, p. 79-80, fig. 33. Hartman, 1944 a, p. $72-73$. 1968, p. 695,3 figs.

1 exemplar incompleto (AK 05, BAC), com 36 setígeros anteriores, medindo cêrca de $28 \mathrm{~mm}$ de comprimento.

Descrição - Espécie pequena mas robusta. Corpo aproximadamente cilíndrico na região anterior $\mathrm{e}$ comprimido, de secção elíptica, na região mediana; com os 5 primeiros setígeros muito mais longos que os subseqüentes.

Prostômio bem conformado; palpos globulosos; antenas frontais piriformes; antenas occipitais longas. com ceratóforos curtos e inconspìcuamente anelados; um par de olhos punctiformes, junto à base das antenas laterais internas.

Cirros tentaculares longos, subulados.

Parapódios dos 4 primeiros setígeros implantados junto à margem anterior do segmento; muito largos, com cirros grossos, longos e subulados e o lóbulo post-setal mais longo que as cerdas. A partir do $6 .^{\circ}$ setígero o cirro ventral é substituído por uma simples saliência em forma de almofada; o lóbulo post-setal se reduz gradualmente, tendendo a desaparecer após o $15 .^{\circ}$.

O $5 .^{\circ}$ setígero é mais curto que os anteriores, porém ainda cêrca de duas vêzes mais longo que os seguintes.

Ganchos pseudo-compostos, encapuzados, dos segmentos anteriores, tridentados, com o dente apical fortemente curvo e o dente accessório inferior pequeno mas conspícuo (Fig. 38 e 39).

Setígeros $6 .^{\circ}$ a $15 .^{\circ}$ com cerdas simples, limbadas e 1 ou 2 cerdas compostas, com artículo cultriforme (Fig. 40). A partir do $16 .^{\circ}$ setígero, desaparecem as cerdas compostas, persistindo as cerdas simples, acom. panhadas por cerdas pectinadas e dois ganchos sub-aciculares, bi-dentados, robustos (Fig. 41 e 42). Acículos com extremidade afilada e proeminente (Fig. 43).

Brânquias cirriformes, simples, a partir do $16 .^{\circ}$ setígero; constituídas, até o $36^{\circ}$ (último do fragmento) por um único filamento mais longo que o cirro dorsal.

Mandíbulas inteiramente brancas, translúcidas, com a aparência de porcelana; bem desenvolvidas.

O exemplar é de côr uniforme, amarelada, sem vestígios de uma possível pigmentação, como a descrita por Hartman.

Discussão - Onuphis litoralis Monro, se caracteriza, segundo as descrições do autor e de HaRTMaN (1944a) pela conformação peculiar dos primeiros setígeros, pela ausência de brânquias na região anterior e pelos ceratóforos quase lisos (com anelação indistinta)

Uma comparação minuciosa do nosso exemplar, com as referidas descriçôes, nos permite considerar como indubitável a sua identidade com a espécie de Monro.

A presença de 4 setígeros anteriores "hipertrofiados" em lugar dos 3 descritos por Monro não constitui, a nosso vêr, uma discrepância expressiva. MoN. Ro (p. 78) faz menção explícita a um "pescoço" cilíndrico constituído pelos primeiros 3 ou 4 setígeros; 
dos quais o $4 .^{\circ}$ é "more or less transitional". Como, no início da descrição o autor diz que: "The body is elongate and, except for the first four or five chaetigers, dorso-ventrally flattened", depreendemos que, em alguns dos seus espécimens o $4 .^{\circ}$ setígero era, também, cilíndrico e incluído no "pescoço". Hartman, na descrição do seu exemplar, não faz referência a essa característica.

A posição da primeira brânquia do nosso exemplar, no $16 .^{\circ}$ setígero é mais próxima da descrita por Monro e a presença de cerdas compostas com artículo cultriforme foi constatada, com certeza, nos pés $6 .^{\circ}$, $11 .^{\circ}$ e $12 .^{\circ}$, sendo inexistentes após o $15 .^{\circ}$ (preparaçôes examinadas ao microscópio), o que coincide com o referido por Monro.

O. litoralis é uma espécie bastante rara e todos os exemplares examinados até o presente - 75, das Ilhas Galapagos, por Monro e 1, da Califórnia, por Hartman - são, como o atual, incompletos na região posterior (o fragmento mais longo, examinado por Monro, era constituído por 85 setígeros anteriores).

Distribuição - Ilhas Galapagos; Ilha San Nicolas (Califórnia) (Hartman, 1968); Nordeste do Brasil (Alagoas).

\section{Família EUNICIDAE Savigny 1818}

Eunicidae sensu Hartman, 1944a, p. 96-98

A taxonomia dos Eunicidae é particularmente difícil. A família é uma das mais antigas e tem um número muito grande de espécies, com ampla distribuição. Vários dos caracteres de importância taxonômica, geralmente conspícuos nos Eunicidae, são susceptíveis de acentuado polimorfismo ou são efêmeros, parcial ou totalmente deformados pelas técnicas de preservação.

A tais dificuldades, se somam as oriundas de descrições incorretas, inócuas ou por demais suscintas. Mesmo descrições cuidadosas são de limitado valos, quando baseadas n'um ou em poucos exemplares. É quase sempre possivel reconduzir um exemplar isolado a um determinado "tipo"; as dificuldades surgem quando devemos identificar e, conseqüentemente, caracterizar uma espécie amplamente representada n'uma coleção.

Hartman (1944a, p. 98-100) discute, concisamente, o problema em relação ao gênero Eunice e propõe "menos falíveis meios de determinação". Entretanto, o problema persiste e se agrava.

Quando as descrições das espécies desta coleção já se encontravam prontas, tomamos conhecimento do trabalho de Fauchald (1969, A revision of six species of the flavus-bidentatus group of Eunice). Pareceu-nos, na ocasião, que êsse trabalho poderia dirimir nossas dúvidas quanto à correta identificação de uma das espécies melhor representadas em nosso material e tida como Eunice longicirrata Webster.
Fauchald conclui (p. 14) que Eunice websteri (nôvo nome para $E$. longicirrata) "has been confused with at least three of the species treated here, E. bianrulata, E. valens and E. kobiensis;...". A nosso vêr, a situação permanece inalterada; tendo o autor caracterizado e distinguido apenas os holótipos, persiste a dúvida quanto à significância da diversidade que se constata ao examinar um número razoável de exemplares presumivelmente da mesma espécie.

No material coletado pelo "Akaroa", estão representados 4 gêneros e 1 sub-gênero de Eunicidae: Eunice, Lysidice, Marphysa, Palola e Nicidion.

Chave para as espécies da família Eunicidae, desta coleção:

1. Com 5 antenas $\ldots \ldots \ldots \ldots \ldots \ldots \ldots \ldots$

- Com 3 antenas; gênero Lysidice ....... .................... Lysidice ninetta

2. Com cirros occipitais $\ldots \ldots \ldots \ldots \ldots \ldots$

- Desprovidos de cirros occipitais; gênero Marphysa ......................

3. Com cerdas pectinadas e ganchos sub-aciculares; gênero Eunice ..............

- Desprovidos de cerdas pectinadas e de ganchos sub-aciculares; gênero Palola ....... $\ldots \ldots \ldots \ldots \ldots \ldots$ Palola siciliensis

4. Com brânquias bem desenvolvidas, geralmente pectinadas; gênero Eunice sensu

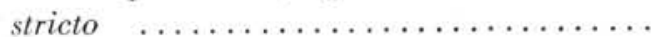

- Brânquias reduzidas a um filamento único, ou ausentes; sub-gênero Nicidion ....... 12

5. Com ganchos sub-aciculares bi-dentados .. 6

- Com ganchos sub-aciculares tri-dentados ..

6. Ganchos sub-aciculares de côr clara, amarela (Grupo "flavus-bidentate" *). Brânquias apenas nos segmentos anteriores ....

- Ganchos sub-aciculares de côr escura ou negra (Grupo "fuscus-bidentate" *). Brânquias até os últimos segmentos ........

7. Antenas com artículos aproximadamente ciTíndricos; a mediana com 8-10 segmentos. Cirros occipitais muito longos, alcançando o bordo anterior do prostômio ........... $\ldots \ldots \ldots \ldots \ldots \ldots \ldots$ Eunice longicirrata

- Antenas moniliformes; a mediana com 12.20 segmentos. Cirros occipitais alcançando apenas o bordo do segmento bucal ..... $\ldots \ldots \ldots \ldots \ldots$ Eunice biannulata

Hartman, 1944a, p. 99-104. 
8. Brânquias simples, com um ou dois filamentos longos; a $1 .^{\mathrm{a}}$ no $13 .^{\circ}-15 .^{\circ}$ setígero ...................... Eunice guanica

- Brânquias pectinadas com 5-8 ramos, nos segmentos anteriores e medianos ........

9. $1 .^{a}$ brânquia no $3 .^{\circ}-4 .^{\circ}$ setígero, com um único filamento .......... Eunice floridana

- $1 .^{\mathrm{a}}$ brânquia no $5 .^{\circ}-6 .^{\circ}$ setígero, com cêrca de 5 filamentos ........... Eunice tridentata

10. Brânquias até os últimos segmentos; as da região anterior, pectinadas, com 10-12 ra$\operatorname{mos} \ldots \ldots \ldots \ldots \ldots \ldots \ldots$ Eunice rubra

- Brânquais apenas nos segmentos anteriores 11

11. Prostômio com o bordo anterior inteiro, não incisado. $1 .^{\mathrm{a}}$ brânquia no $3 .^{\circ}$ setígero $\ldots \ldots \ldots \ldots \ldots \ldots \ldots$ Eunice vittata

- Prostômio fendido (bi-lobado). 1. ${ }^{\mathrm{a}}$ brânquia no $5 .^{\circ}$ setígero ..... Eunice binominata

12. Com brânquias em alguns segmentos da região mediana e posterior ............. .............. Eunice (Nicidion) cariboea

- Sem brânquias ................ 13

13. Ganchos sub-aciculares aparecendo no $60 .^{\circ}$ setígero; almofadas neuropodiais até cêrca de $70 .^{\circ}$ setígero $\ldots \ldots \ldots \ldots \ldots \ldots$ ............ Eunice (Nicidion) imogena

- Ganchos sub-aciculares a partir do $25 .^{\circ}-26 .^{\circ}$ setígero; almofadas neuropodiais limitadas a poucos segmentos anteriores .......... ........... Eunice (Nicidion) kinbergi

14. Prostômio profundamente fendido. Brânquias sub-pectinadas, com 4-5 filamentos, onde melhor desenvolvidas .. Marphysa regalis

- Prostômio apenas incisado no bordo anterior. Brânquias constituídas por um único filamento ....... Marphysa stylobranchiata

Gênero Eunice Rafinesque 1815

Eunice cf. biannulata Moore 1904

Eunice biannulata Moore, 1904, p. 487-490, est. 37, fig. 10-18; est. 38, fig. 42. Fauchald, 1969, p. $2-4$, fig. 1 .

5 exemplares completos, fragmentados (AK 56, BAC; AK 59, ACL e AK 121, BAC), o maior dos quais com cêrca de 100 setígeros, medindo $52 \mathrm{~mm}$ de comprimento.

Esta espécie, identificada com certa reserva, é muito próxima de E. longicirrata Webster. Distingue-se desta, essencialmente pelas antenas conspicuamente moniliformes, com segmentos mais numerosos (18-20 na antena mediana) e pelos cirros occipitais muito mais curtos.

Sutis diferenças na forma das cerdas compostas e nos ganchos sub-aciculares dificilmente podem ser consideradas de importância taxonômica. Na realidade, constatamos uma ampla variação no comprimento e forma dos dentes de tais cerdas, assim como no ângulo que formam com a haste. Em alguns casos, essa variação pode ser observada entre as cerdas de um mesmo pé.

Ainda assim, parece-nos que a espécie é suficientemente distinta de longicirrata e somos inclinados a concordar com Fauchald, considerando-a uma boa espécie.

Hartman, 1961 (p. 23), dá prioridade a longi. cirrata; porém, em 1968 (p. 715) parece considerar as duas espécies como idênticas, ao referir e descrever biannulata com figuras anteriormente (1944a) atribuídas à primeira.

Distribuição - E. biannulata era conhecida da Califórnia do Sul e do México ocidental (Fauchald); sua ocorrência no Nordeste do Brasil (Alagoas e Sergipe) é, portanto, inédita.

\section{Eunice binominata Quatrefages 1865}

(Fig. 44-50)

Eunice binominata Quatrefages. Ehlers, 1887, p. 85. Augener, 1906, p. 132, est. 4, fig. 60-63. Treadwell, 1921, p. 36-39, fig. 95-106, est. 3, fig. 9-12.

4 exemplares (AK 31, BAC e AK 132, ACL), dos quais 2 completos, com cêrca de 100 setígeros e medindo $54 \mathrm{~mm}$ de comprimento.

Descrição - Espécie pequena e robusta; corpo ligeiramente comprimido na região anterior e achatado, afilando ràpidamente, na região posterior. Prostômio com o bordo profundamente fendido (bi-lobado) ; antenas longas, moniliformes. Um par de olhos, grandes, entre os pontos de inserção das antenas laterais. Cirros tentaculares conspìcuamente articulados (Fig. 44). Parapódios anteriores com cirros dorsais e ventrais longos, subulados. Cirros ventrais dos setígeros medianos e posteriores, curtos, piriformes, inseridos sôbre pregas em forma de almofada elíptica (Fig. 46).

Primeira brânquia no $5 .^{\circ}-6 .^{\circ}$ setígero; constituída por um único filamento muito longo. Nos segmentos seguintes as brânquias são pectinadas e o número de filamentos alcança cêrca de 10 , entre o $10 .^{\circ}$ e o $20 .^{\circ}$ setígeros, diminuindo gradualmente para desaparecer após o $300^{\circ}-32 .^{\circ}$. A região posterior é desprovida de brânquias.

Cerdas dos setígeros anteriores de 3 tipos: a) capilares, ligeiramente limbadas, geniculadas; b) 
compostas, com artículo bi-dentado, encapuzado e c) pectinadas, com dentes numerosos e processos laterais longos e muito finos (Fig. 47 a 49). Ganchos sub-aciculares tri-dentados, amarelos, aparecendo após o $20 .^{\circ}$ setígero (Fig. 50 ).

Pigídio com dois uritos, longos e articulados (Fig. 45).

Discussão - Eunice binominata Quatrefages, assemelha-se a $E$. vittata (delle Chiaje) e a $E$. rubra Grube, espécies que têm ampla distribuição no Atlântico tropical americano.

Essa circunstância nos levou a examinar com particular atenção os exemplares do gênero Eunice, coletados pelo "Akaroa". Após a apreciação cuidadosa dos caracteres dos exemplares aqui descritos, concluímos pela sua identidade com a espécie de Quatrefages, conforme as descrições de Augener e de Treadwell.

As três espécies pertencem ao grupo "flavus tridentate" de Hartman; porém podem ser distinguidas umas das outras, por caracteres conspícuos.

E. vittata tem prostômio inteiro e arredondado, não fendido; antenas com artículos longos; cirros tentaculares e cirros parapodiais indistintamente segmentados; brânquias apenas no terço anterior do corpo, começando no $3 .^{\circ}$ setígero.

E. rubra tem prostomio fendido; antenas e cirros conspìcuamente moniliformes, brânquias do $5 .^{\circ}$ ao último setígero.

Em E. binominata, o prostômio é bi-lobado; cirros e antenas têm articulação nítida, com segmentos relativamente longos (não exatamente "moniliformes") e as brânquias desaparecem após a metade do corpo. Em nossos exemplares, o desaparecimento das brânquias é ainda mais precoce: no $32 .^{\circ}$ setigero, em exemplar com cêrca de 100 segmentos.

A presença de brânquias apenas na região anterior do corpo é um carácter constante; Ehlers (1887) e Augener (1906) mencionam brânquias do $5 .^{\circ}$ ao $300^{\circ}$ pé, em exemplares das Tortugas, St. Cruz e Barbados.

Quanto ao pequeno número de ramos branquiais e à sua aparência peculiar, "alveolada" (Fig. 46) foram constados também por Augener (p. 132 e est. 4, fig. 60).

Da região indo-pacífica é conhecida Eunice australis Quatrefages, espécie que nos parece muito próxima, senão indistinguível de binominata.

É, portanto, possível que o exemplar descrito por Monro (1928) das costas do Panamá, como E. australis, pertencesse realmente à espécie binominata.

Distribuição - Bermudas; Antilhas: Barbados, Tortugas, Sta. Cruz (Treadwell, 1921); Nordeste do Brasil (Alagoas e Sergipe).
Eunice floridana (Pourtalés) 1869

(Fig. 51-53)

Eunice floridana (Pourtalés). Ehlers, 1887, p. 88, est. 22, fig. 1.7. Hartman, 1942a, p. 49-52, fig. 85-87. 1951, p. 56-57. Fauvel \& Rullier, 1959 a, p. 937.

Leodice floridana (Pourtalés). Treadwell, 1921, p. 33-34, fig. 77-84.

? Eunice floridana (Pourtalés). Fauvel, 1953, p. 235, fig. 177 a'-g'.

Eunice multipectinata Moore. Luna, 1969.

3 exemplares completos (AK 47, BAC e AK 57, $\mathrm{BAC}$ ), o maior com cêrca de 130 setígeros, medindo $120 \mathrm{~mm}$ de comprimento.

12 fragmentos anteriores (AK: 04, 48, 53, 57, 59,64 e 85 ).

Descrição - Espécie robusta, com o corpo longo, de secção elíptica, comprimido e afilado na região posterior. Prostômio arredondado, fendido. Antenas relativamente curtas, articuladas; a mediana com 10.12 e as laterais com cêrca de 8 segmentos cilíndricos, curtos. Cirros occipitais e cirros parapodiais segmentados. Brânquias do $4 .^{\circ}-5 .^{\circ}$ até os últimos setígeros; a primeira com um único filamento, curto; as seguintes pectinadas, com um máximo de 10-11 ramos, entre $10 .^{\circ}$ e $40 .^{\circ}$ setígeros; reduzidas a um ou dois filamentos na região mediana e posterior do corpo. Cirros dorsais extremamente longos, ultrapassando o comprimento total das brânquias mesmo onde melhor desenvolvidas (Fig. 51 e 52).

Artículo das cerdas compostas longo, com o dente accessório quase tão grande quanto o dente distal (Fig. 53).

Ganchos sub-aciculares castanho escuro ou negros, bi-dentados, a partir do $26 .^{\circ}-27 .^{\circ}$ setígero; em número de $1 \mathrm{ou}$, raramente, de 2 em cada pé.

Aparêlho bucal com o suporte do forceps triangular afilado, com expansões aliformes; maxilas II com 4 e 5 dentes grossos; max. III com $6 ; \max$. IV, com 4-6 e 7-9 em placa curva (Fig. 54).

Pigídio com dois uritos longos, articulados.

Côr, no álcool - Castanho claro, iridescente; com uma faixa transversal mais clara, sôbre o $3 .^{\circ}$ setígero.

Discussão - Eunice floridana (Pourtalés) pertence ao grupo "fuscus-bidentate" de Hartman. Essa característica, aliada ao comprimento excepcional dos cirros dorsais e à presença de brânquias até a extremidade posterior, a distingue das espécies próximas: $E$. longicirrata e $E$. biannulata, que também ocorrem nesta região.

A distinção entre $E$. floridana e $E$. multipectinata Moore, porém, nos parece problemática. É possível 
que o cirro dorsal, relativamente mais curto em multipectinata, constitua um carácter suficientemente constante para diferenciar as duas espécies. As figuras de Moore (1911, est. 15, fig. 20-23) são insuficientes para uma comparação mais acurada.

A circunstância de ser E. floridana das duas espécies a melhor conhecida e com ampla distribuição no Atlântico tropical americano constitui mais um fator para que consideremos a ela pertencendo os nossos exemplares.

A identidade entre $E$. floridana e $E$. norvegica Linneu, admitida por Pettibone (1963, p. 240) e Day $(1967$, p. 388) seria, a nosso vêr, desconcertante.

Reconhecemos que uma tomada de posição implica, òbviamente, em admitir certas premissas, o que redunda n'um círculo vicioso. Porém, quando há evidências de que $E$. floridana, descrita da Flórida, ocorre hàbitualmente associada a corais (Fauvel, 1953 e Pettibone, 1963) nos parece temerário identificá-la com uma espécie da Noruega.

Distribuição - Antilhas e costa oriental dos Estados Unidos (Hartman, 1951). Oceano Índico, Atlântico e Mediterrâneo (Fauvel, 1953). Nordeste do Brasil (Alagoas).

Eunice guanica (Treadwell) 1921

Leodice guanica Treadwell, 1921, p. 39-40, fig. 107-116 ; est. 2, fig. 9-12.

Eunice guanica (Treadwell). Hartman, 1944a, p. $111 \cdot 112$, est. 6, fig. 142-144.

1 pequeno exemplar (AK 26, H), com cêrca de 100 setígeros, medindo $55 \mathrm{~mm}$ de comprimento.

A identificação inicial, feita por ocasião da triagem, não pôde ser confirmada, em conseqüência da desintegração acidental do exemplar.

A presença de brânquias com 2-3 filamentos, a partir do $15 .^{\circ}$ setígero e os ganchos sub-aciculares bi-dentados e de côr castanha ou negra, coincidem com os caracteres específicos referidos por Hartman.

Distribuição - Panamá; Antilhas (Hartman, 1944a): Nordeste do Brasil (Alagoas).

Eunice longicirrata Webster 1884.

(Fig. 60-62)

Eunice longicirrata Webster, 1884, p. 318-319, est. 12, fig. 75-80. Hartman, 1944a, p. 104-107, est. 6, fig. 75-80. Hartmann, $1944 \mathrm{a}$, p. 104-107, est. 6, fig. 118-122.

Leodice longicirrata (Webster). Treadwell, 1921, p. 11-14, fig. 3-12; est. 1, fig. 1-4.

8 exemplares completos e cêrca de 100 fragmentos anteriores (AK: 12, 14, 40, 41, 43, 48, 53, 59, $63,67,68,74,91,95,102,132$; CAN 120 e 125).
Descrição - Espécie de tamanho mediano. Corpo longo, de secção aproximadamente cilíndrica, com cêrca de 120 setígeros. Prostômio bi-lobado; antenas longas e multi-articuladas, com segmentos cilíndricos; cirros occipitais muito longos, alcançando o bordo anterior do prostômio (Fig. 60). Cirros dorsais articulados.

Brânquias pectinadas, limitadas à região anterior do corpo; a $1 .^{\mathrm{a}}$ no $4 .^{\circ}-5 .^{\circ}$ setígero, com um único filamento; as subseqüentes alcançando um máximo de 10 ramos, entre o $10 .^{\circ}$ e $30 .^{\circ}$ pés, decrescendo ràpidamente, para desaparecer após o $37 .^{\circ}-400^{\circ}$.

Ganchos sub-aciculares amarelos, bi-dentados, a partir do $200^{\circ}$ setígero.

Aparêlho bucal robusto, de côr clara; forceps com suportes retangulares e sem expansóes aliformes; maxilas II com 7.8 e 6-7 dentes grossos; maxila III com cêrca de 7 dentes; maxilas IV com 6-8 e 10-12 dentes, em placa serrilhada, curva (Fig. 61).

Discussão - Eunice longicirrata Webster é a espécie melhor representada nesta coleção, o que permitiu um estudo comparativo e uma apreciação ponderada de suas características.

A "somewhat confused original description", mencionada por Hartman (1944a), foi emendada por Treadwell (1921), que dispôs de farto material da mesma procedência.

Esta espécie é muito próxima de $E$. biannulata Moore. Hartman, que em 1961 as considerava dis. tintas, aparentemente concluiu pela identidade entre ambas, pois reproduz suas figuras de longicirrata, na descrição de E. biannulata (1968, p. 715).

N'um trabalho muito recente, Fauchald (1969) revendo algumas espécies do grupo flavus-bidentatus, re-descreve o tipo de $E$. longicirrata, atribuindo-lhe um nôvo nome: $E$. websteri.

Infelizmente, Fauchald não deu importância às características do aparêlho bucal: "the jaws appear to be of the usual kind".

Concluímos pela validade da espécie, conforme redescrita por Treadwell e por Hartman.

E. longicirrata tem antenas com artículos cilíndricos; cirros occipitais tão longos quanto o prostômio e maxilas II com 6-8 dentes.

E. biannulata tem antenas moniliformes, com artículos mais numerosos; cirros occipitais alcançando apenas o bordo anterior do segmento bucal e maxilas II com 4-5 dentes.

Uma eventual confusão entre $E$. longicirrata e E. multipectinata, como lembrado por Fauchald é perfeitamente susceptível de ocorrer. Porém, ainda que se assemelhem em alguns de seus caracteres super. ficiais, E. multipectinata tem ganchos sub-aciculares negros, pertencendo portanto ao grupo "fuscus-bidentate". 
Distribuição - Bermudas, Flórida, Antilhas até o Nordeste do Brasil (Alagoas e Sergipe).

\section{Eunice rubra Grube 1856}

Eunice rubra Grube, 1856, p. 59. Ehlers, 1887, p. 87-88, est. 26, fig. 1-11. Hartman, 1944a, p. 117, est. 7, fig. 151-153. Rullier, 1965 , p. 30-31. Nonato, 1966a, p. 69.

Leodice rubra (Grube). Treadwell, 1921, p. 15-17, fig. $13-20$; est. 2 , fig. 1-4.

Eunice ornata Andrews, 1891, p. 284-285, est. 13, fig. 13-20.

6 exemplares completos (AK 02, ACL; AK 31, BAC; AK 61, ACL; AK 82, ACL e AK 132, ACL), o maior dos quais, com 100 setígeros e medindo 52 $\mathrm{mm}$ de comprimento.

25 fragmentos anteriores (AK: 03, 06, 15, 27, $48,50,76,83,85,88,93$ e 100$)$.

Descrição - Corpo longo, de secção aproximadamente cilíndrica na região anterior e elíptica, ligeiramente achatado, na região mediana e posterior. Prostômio bi-lobado; antenas longas, conspìcuamente moniliformes; dois olhos grandes, na base das antenas laterais. Cirros occipitais e cirros parapodiais lisos ou com segmentação indistinta.

Brânquias pectinadas, longas, a partir do $5 .^{\circ}$ até o último setígero; com um máximo de 8.12 ramos nos setígeros $100^{\circ}$ a $20 .^{\circ}$ e reduzindo-se a 2 ou 3 após o $30^{\circ}$ Cirro dorsal muito longo, alcançando cêrca de metade do comprimento total da brânquia. Acículos amarelos, com ponta saliente, discretamente dilatada e bífida. Ganchos sub-aciculares robustos, amarelos e tridentados. Cerdas compostas, com artículo longo, bi-dentado; cerdas pectinadas com dentes muito finos e numerosos.

Mandíbulas com pesada incrustação calcária no bordo cortante. Maxilas de côr cinza-claro, com bordos mais escuros; forceps robusto; max. II com 4-5 dentes; III com 8 dentes; IV em placa curva, serrilhada.

Discussão - Eunice rubra Grube, que pertence ao grupo "flavus-tridentate" de Hartman, aproxima-se muito de E. antennata Savigny. Porém acreditamos, como Hartman (1944a, p. 104 e 117), que as brânquias, reduzidas a 1 ou 2 filamentos nos setígeros da região posterior e os acículos, mais leves e inconspicuamente bifurcados, caracterizam suficientemente E. rubra.

Acresce ainda, que E. antennata, descrita por Savigny, do Gôlfo de Suez, tem distribuição preponderantemente indo-pacífica.

Eunice rubra foi descrita das Antilhas e sua distribuição atual abrange o Gôlfo do México e a costa leste dos Estados Unidos, até a Carolina do Norte.
Os exemplares coletados pelo "Meteor" nas costas de Pernambuco e atribuídos por Augener (1931, p. 289) a esta espécie, pertenceriam, muito provàvelmente, a uma espécie próxima, isto é $E$. binominata Quatrefages. Augener, na descrição, menciona explìcitamente "eine auf den Vorderkörper beschränkte, am 27. Parapod endigend Kiemenzone"; peculiaridade que, por si só, distingue amplamente binominata de rubra.

A descrição de Ehlers, de E. rubra da Flórida, aplica-se corretamente ao nosso material. Conformação das antenas e dos cirros parapodiais, assim como a forma das cerdas, das brânquias e do aparêlho bucal, são idênticas.

Eunice brasiliensis Kinberg, de Pernambuco, parece ser uma espécie indistinguível da atual. Porém, como Kinberg não descreveu os ganchos sub-aciculares, a sua identificação nos parece inexequível. Hartman, em sua revisão dos tipos de Kinberg (1948) também não descreveu essa espécie.

Distribuição - Atlântico americano, da Carolina do Norte ao sul do Brasil.

\section{Eunice cf. tridentata Ehlers 1905}

(Fig. 55-58)

Eunice tridentata Ehlers, 1905, p. 288, est. 9, fig. 3-10. Monro, 1933, p. 63-64, fig. 26. Hartman, 1944 a, p. 114 , est. 7 , fig. 145-150.

2 fragmentos anteriores (AK 04, BAC e AK 49, BAC), com 40 setígeros, medindo cêrca de $38 \mathrm{~mm}$ de comprimento.

Descrição - As proporções são as de uma es. pécie de porte mediano. Corpo robusto, de seç̧ão elíptica. Prostômio profundamente bi-lobado; antenas e cirros occipitais longos, com a superfície ligeiramente pregueada; dois olhos grandes na base das antenas laterais. Cirro dorsal do primeiro setígero muito grande, piriforme-subulado. Primeira brânquia no $5 .^{\circ}$ setígero, já com 5 filamentos longos. O número de ramos branquiais alcança um máximo de 8 , entre o $10 .^{\circ}$ e $200^{\circ}$ pés e decresce nos subseqüentes; o $400^{\circ}$ setígero (último do fragmento) tem a brânquia reduzida a 3 ramos curtos.

Cerdas compostas com artículos encapuzados, de proporções e configuração variáveis. As que nos parecem mais perfeitas tem a extremidade bi-dentada, com o dente accessório relativamente longo e bem conformado e um terceiro "dente" (?) basal, conspícuo (Fig. 55). As mais simples têm o artículo muito curto, triangular ou unciforme, pràticamente liso (Fig. 58). Os artículos da maioria das cerdas, porém, têm características intermediárias entre os dois tipos extremos (Fig. 56 e 57).

Cerdas pectinadas, largas com um processo la. teral alongado. 
Ganchos sub-aciculares discretamente bi-dentados, de côr predominantemente clara, a partir do $35 .^{\circ}-37 .^{\circ}$ setígero.

Acículos castanhos escuro, proeminentes, em número de 2 por pé.

Aparêlho bucal robusto; suporte do forceps triangular, com expansões aliformes; forceps curto e largo; maxila II com 4 e 5 dentes grossos e bem recortados; maxilas III e IV em placas curvas, irregularmente denteadas.

Coloração, no álcool - castanho-avermelhado, iridescente; brânquias "alveoladas", com manchas pretas dispersas.

Discussão - Eunice tridentata Ehlers seria caracterizada, como indica o nome específico, pela presença de cerdas compostas com artículos falciformes "tridentados". A existência dêsse $3 .^{\circ}$ dente nos parece discutível e, não fôssem outros caracteres accessórios, não seria suficiente para distinguir a espécie.

Hartman (1944a, p. 114) evidencia precisamente essa peculiaridade: "A wekly developed guard, when worm way, gives the appearence of a tridentate condition".

A forma de tais cerdas é realmente singular e não decorre exclusivamente do desgaste de cerdas comuns; a freqüência alta e a regularidade dos tipos mais simples sugere que a maioria seja constituída por cerdas intactas.

A peculiaridade está, não no "terceiro dente", mas no tamanho e forma variável do artículo.

É possível, ainda, constatar uma certa imprecisão nas diagnoses, tanto de Ehlers quanto de autores mais recentes.

Hartman considerou que seus exemplares concordavam bem com os de Monro (do Panamá), mas que diferiam em alguns aspectos, do original da Nova Zelândia. Entretanto, a seguir, reconhece que a descrição de Ehlers foi "corrected on some points and enlarged by Augener (1924, p. 402) who re-examined the type material".

Os nossos exemplares têm caracteres idênticos aos referidos por Ehlers e Augener, inclusive em relação aos ganchos sub-aciculares de côr amarela. Este último carácter indica que $E$. tridentata pertence ao grupo "flavus-bidentate".

Não nos parece, portanto, provável que a espécie seja sinônimo de E. valens Chamberlin, como sugerido por Hartman (1961, p. 63) e tão pouco o será de E. schmacephala Schmarda e E. fucata Ehlers, ambas da Flórida.

A única discrepância significativa entre o nosso material e o de Ehlers, estaria no número de dentes da maxila II. A fig. 4 de Ehlers mostra, de forma inequívoca, 6 a 7 dentes; porém, segundo Hartman "it is said to have only 4 or 3 teeth"(?).
Distribuição - Tropical: distribuída irregularmente através do Mar das Antilhas (Jamaica, Barbados) e costa pacífica do Panamá (Jones, 1962). Nordeste do Brasil (Alagoas).

\section{Eunice cf. vittata (delle Chiaje) 1828}

Eunice vittata (delle Chiaje). Fauvel, 1923, p. 404 -405, fig. 158, h-n. Hartman, 1944a, p. 118. Day, 1967, p. 385, fig. 17.3, a-e.

Leodice unifrons Verrill. Treadwell, 1921, p. 17-20, fig. $21-30$; est. 1, fig. 5-9.

1 exemplar incompleto (AK 06, BAC) com 40 setígeros anteriores, medindo cêrca de $11 \mathrm{~mm}$ de comprimento.

Descrição - Espécie pequena e robusta. Corpo de seç̧ão elíptica, comprimido na região mediana e posterior. Prostômio arredondado, com o bordo anterior inteiro, não fendido; antenas com 6-7 artículos longos; olhos grandes, entre as antenas laterais. Cirros tentaculares e cirros dorsais sem articulação aparente. Brânquias apenas na região anterior, a partir do $3 .^{\circ}$ setígero; com $3-4$ filamentos onde melhor desenvolvidas.

Ganchos sub-aciculares tri-dentados, amarelos. Acículos proeminentes, com ponta arredondada.

Discussão - Eunice vittata (delle Chiaje) pertence ao grupo "flavus-tridentate" de Hartman. A êsse grupo pertencem também $E$. rubra Grube e $E$. australis Quatrefages, das quais esta espécie se distingue pela posição da $1 .^{\mathrm{a}}$ brânquia, no $3 .^{\circ}$ setígero e pelas características do prostômio, não fendido.

Fauvell \& Rullier (1957, p. 82), a propósito da semelhança entre $E$. vittata e $E$. indica Kinberg, dizem: "Cette espèce est très voisine de Eunice indica Kinberg qui a aussi des antennes lisses et longues, des branchies à partir du $3 .^{\circ}$ sétigère et les mêmes soies aciculaires tridentées".

Porém, vários autôres têm descrito as antenas como segmentadas ou aneladas; (Knox, 1960, p. 125: " $E$. vittata is distinguished from $E$. indica in that it has annulated antennae, not smooth, and a single sub-acicular hook instead of 4 or 5"; Hartman, 1966, p. 216: "Prostomial antennae annulate, with long, cylindrical articles") e, também Ehlers as figurou as$\operatorname{sim}$ (1868, est. 15, fig. 15).

O exemplar desta coleção é pequeno, porém perfeitamente conservado e aproxima-se muito dos descritos por Hartman (do Pacífico oriental). O tamanho é semelhante (25-35 $\mathrm{mm}$ os de Hartman, completos) assim como as brânquias, com pequeno número de filamentos e desaparecendo antes do $40^{\circ}$ setígero. Difere, portanto, dos exemplares da África do Sul, aos quais Day atribui brânquias até o $45 .^{\circ}$ setígero e com 10-20 filamentos (no $200^{\circ}$ pé). 
Tais diferenças podem, indubitàvelmente, ser atribuídas ao maior desenvolvimento dos animais. Entretanto, parece-nos admissível a existência de uma variedade ou sub-espécie que corresponderia à diagnose de Leodice unifrons Verrill, espécie que, segundo Treadwell (p. 17-18), alcança $50 \mathrm{~mm}$ de comprimento (como a sul africana) e cujas brânquias têm um máximo de 6 filamentos. A forma européia, segundo FAUveL (1923) - muito maior $(40-100 \mathrm{~mm}) \mathrm{e}$ tem brânquias com um máximo de 14 filamentos.

A identificação é feita com certa reserva por tratar-se de um único espécimem, incompleto e provàvelmente jovem.

Distribuição - Atlântico, da Inglaterra e North Carolina até a Africa Ocidental: Mediterráneo; Califórnia do Sul; Japão (DAY, 1967); Nordeste do Brasil (Alagoas).

\section{Eunice (Nicidion) cariboea Grube 1856)} (Fig. 59)

Eunice (Nicidion) cariboea Grube. Hartman. 1944a, p. 123-124, est. 7, fig. 157-163; est. 8, fig. 178.

Leodice culebra Treadwell, 1921, p. 49, fig. 144-153; est. 2, fig. 13-16.

non Leodice cariboea Treadwell, 1921, p. 47.

1 fragmento posterior (AK 31, BAC), com cêrca de 200 setígeros, medindo $85 \mathrm{~mm}$ de comprimento.

A identificação é feita com reservas, devido à falta da região anterior. Porém, as características dos setígeros remanescentes correspondem exatamente às descritas e figuradas por Treadwell e por Hartman.

Brânquias unifilares, muito longas, ocorrem esporàdicamente na região que presumimos ser a mediana e em todos os setígeros da região posterior, exceto os 6-8 últimos.

A Figura 59, de um dos primeiros setígeros do fragmento, é pràticamente idêntica à fig. 161 de HARTMAN (1944a, est. 7). Tal identidade, aliada à das cerdas, caracteriza razoàvelmente bem o nosso material.

Distribuição - E. (Nicidion) cariboea era conhecida das Antilhas; sua presença no Gôlfo da Califórnia, referida por HaRTMAN em 1944a, não foi confirmada pela autora em publicações mais recentes (1961 e 1968). A ocorrência atual estende sua dis. tribuição ao Nordeste do Brasil (Alagoas).

\section{Eunice (Nicidion) imogena Monro 1924}

Nicidion imogena Monro, 1924, p. 61-62, fig. 22-24. Eunice (Nicidion) imogena Monro. Hartman, 1944 a, p. 122.1959 , p. 313 e 325.
1 exemplar incompleto (AK 47, BAC), com cêrca de 280 setígeros anteriores, medindo $125 \mathrm{~mm}$ de comprimento, com um diâmetro de cêrca de $3,5 \mathrm{~mm}$.

Descrição - Corpo muito longo e delgado, de secção uniforme. Prostômio profundamente incisado; antenas cilíndricas, com a superfície corrugada, a mediana cêrca de 1/3 mais longa que o prostômio; olhos em forma decrescente, na base das antenas laterais internas. Cirros occipitais curtos, delgados.

Pés da região anterior com o cirro dorsal muito longo, subulado; lóbulo post-setal triangular, com o ápice arrredondado; cirro ventral digitiforme e, a partir do $8 .^{\circ}$ setígero até o $68 .^{\circ}$, com a base alargada, em forma de almofada oblonga.

Cerdas simples, limbadas e com a extremidade capilar, muito longa; compostas falciformes, com haste robusta e artículo relativamente curto, fortemente bi-dentado; pectinadas, com dentes numerosos e um processo lateral longo. Ganchos sub-aciculares bi-dentados encapuzados, com o dente accessório robusto; presentes em todos os setígeros, a partir do $60 .^{\circ}$, em número de 1 por pé.

A partir do $60 .^{\circ}$ setígero as almofadas que formam a base do cirro ventral, decrescem ràpidamente, tornando-se inconspícuas após o $68 .^{\circ}$. O cirro ventral se reduz, nos segmentos posteriores, a uma simples papila cônica ou cilíndrica.

Até onde pudemos constatar, o exemplar é totalmente desprovido de brânquias.

Maxila II com 4 dentes de cada lado; maxilas III e IV em placas conspicuamente denteadas.

Discussão - O nosso exemplar considerado como de Eunice (Nicidion) imogena, corresponde bem à descrição de Monro; apenas é consideràvelmente maior, sendo admissível que alcançasse, se completo, cêrca de $150 \mathrm{~mm}$ de comprimento.

O tipo e único exemplar da espécie, provém (segundo Monro) de um ponto do Atlântico Sul, ao largo da Bahia $\left(16^{\circ} \mathrm{S}-36 .^{\circ} \mathrm{W}\right)$. É um espécimem completo, com 108 segmentos e $25 \mathrm{~mm}$ de comprimento.

A posição do $1 .^{\circ}$ gancho sub-acicular, no $60 .^{\circ}$ setígero, e a forma peculiar das cerdas simples, extremamente alongadas, são características conspícuas também em nosso exemplar. Porém, a forma da haste das cerdas compostas, cuja extremidade foi descrita como "spoon-shaped and delicately striated" não foi constatada por nós. A fig. 23 de Monro representa, talvez, uma condição excepcional.

O aparêlho bucal, muito descalcificado no nosso exemplar, assemelha-se ao figurado por Monro (fig. 24) .

Consideramos interessante mencionar a forte coloração vermelha que o espécimem transmitiu ao álcool em que está conservado. Característica análoga 
tem sido observada por nós em relação a Arabella setosa Treadwell, que tinge o álcool de intensa côr vermelho-violácea fluorescente.

Quanto ao local de onde provém o tipo, não pudemos localizar a denominação "Hotspur Bank" referida por Monro. De acôrdo com as coordenadas, o mesmo se situaria n'uma área cuja profundidade alcança mais de $4.000 \mathrm{~m}$. A Est. AK 47, na qual foi coletado o espécimem atual, tem uma profundidade de apenas $37 \mathrm{~m}$.

Eunice (Nicidion) cincta Kinberg, parece ser uma espécie muito próxima de imogena. As figuras de DAY (1967, p. 383, fig. 17.2, g-j) mostram o prostômio profundamente bi-lobado, com antenas gros. sas e lisas; características essas idênticas às do nosso exemplar. $\mathrm{O}$ autor menciona "Branchiae entirely absent in small specimens of $25 \mathrm{~mm}$ but represented by one or two filaments on far posterior segments after the $50^{\text {th }}$ foot of adults." Infelizmente, não se refere ao tamanho dêsses adultos, nem ao seu aparêlho bucal.

E. (Nicidion) cincta foi assinalado no Senegal, por FAUvel (1950, p. 362).

Distribuição - Atlântico Sul, ao longo da costa brasileira (Alagoas e Bahia).

\section{Eunice (Nicidion) kinbergi Webster 1884}

Nicidion kinbergi Webster, 1884, p. 320-321, est. 12. fig. 81-82. Treadwell. 1911. p. 7-9, fig. 15-22. 1921, p. 91-93, fig. 324-332; est. 6, fig. 5-8.

Eunice (Nicidion) kinbergi Webster. Hartman, 1944 a, p. 124.1959 , p. 313 e 325.

Eunice cariboea var. kinbergi. Augener, 1931, p. 288. Monro, 1933, p. 63.

1 exemnlar completo (AK 73. L), com 122 setígeros, medindo $32 \mathrm{~mm}$ de comprimento.

Descrição - Espécie pequena: corpo relativamente curto e robusto. Prostômio ligeiramente fendido: antenas comnrimidas. triangulares, pouco mais longas aue o nrostômio: olhos inconspícuos. Cirros occipitais curtos, subulados.

Pés da região anterior com cirros dorsais e ventrais longos e um lóbulo post-setal bem desenvolvido. Nos segmentos medianos o cirro ventral é muito curto, com a base alargada, em forma de almofada.

Cerdas simples, pectinadas e compostas; estas últimas com artículos bi-dentados, extremamente curtos.

Brânquias são totalmente ausentes.

Côr, no álcool - $\mathrm{O}$ nosso exemplar, que aparentemente sofreu uma desidratação intensa, $t: m \mathrm{~m}$ dorso com faixas transversais escuras, uniformemente distribuídas em cada segmento.
Discussão - Augener (1931, p. 288) considera Nicidion kinbergi como a forma abranquiada de Eunice cariboea Grube. Tal opinião é compartilhada por (Monro (1933, p. 63).

Estamos inclinados a concordar com êsses autôres; porém, nosso material nos parece insuficiente para fundamentar uma decisão que admitimos possa ser importante.

Hariman também reconhece a precariedade da distinção entre Eunice sensu stricto e Nicidion, fazendo notar que as espécies dêste sub-gênero são "usually considerably smaller than those of Eunice" diferindo ainda quanto aos caracteres do prostomio e do aparêlho bucal.

Como no caso das brânquias, por definição ausentes em Nicidion, mas presentes em espécies como $\mathrm{ca}$ riboea e gracilis (Hartman, 1944a, p. 122), o pequeno porte e delicadeza dos apêndices prostomiais, podem sofrer exceção. A espécie precedente, Nicidion imogena Monro alcança, como descrevemos acima, tamanho que se iguala ao de muitas espécies de Eunice e tem antenas particularmente robustas.

Mantemos, portanto, a distinção, como o fazem Hartman (1959) e DAY (1967).

Distribuição - Panamá, Antilhas, Colômbia, Trinidad (Hartman, 1944a); Nordeste do Brasil (Alagoas).

Gênero Lysidice Savigny 1818

Lysidice ninetta Audouin \& Milne Edwards 1833

Lysidice ninetta Aud. \& M. Edw.. Fauvel, 1923, p. 411-412, fig. 162, a-g. Tebble, 1955, p. 114.

Day, 1967, p. 403, fig. 17.8, g-i.

Lysidice notata Ehlers, 1887, p. 100-102, est. 30, fig. 1.9 .

2 exemplares completos (AK 04, BAC e AK 101, BAC) com cêrca de 80 setígeros, medindo cêrca de $40 \mathrm{~mm}$ de comprimento.

5 fragmentos anteriores (AK 06, BAC; $\mathrm{AK} 48$, $\mathrm{BAC}$; $\mathrm{AK} 66, \mathrm{BAC}$; AK 72, ACL e AK 146, ACL).

Descrição - Os nossos exemplares são formas pequenas e robustas. Corpo relativamente curto, de secção uniforme até a região posterior, estreitando-se ràpidamente nos últimos segmentos.

Prostômio arredondado, com um entalhe mais ou menos profundo, no bordo anterior. 3 antenas triangulares, sub-iguais, mais curtas que o prostômio. 2 oihos grandes, aproximadamente semi-lunares, na base das antenas laterais.

Ganchos sub-aciculares negros, bi-dentados, a partir do $18 .^{\circ}-20 .^{\circ}$ setígero. Acículos negros. 
Aparêlho bucal constituído por uma mandíbula robusta, com os bordos dobrados para cima, como característico para o gênero. Maxilas II com 4 dentes; maxilas III e IV em placas curvas, irregularmente denteadas.

Discussão - O nosso material não é perfeitamente homogêneo, as características do prostômio variando em certa extensão. Em alguns exemplares o comprimento das antenas iguala o do prostômio; em outros, alcança apenas a sua metade. A forma dos olhos é também variável.

Inicialmente, havíamos atribuído maior importância a tal variação e considerado que pelo menos duas espécies estavam representadas.

Porém, re-examinando cuidadosamente cada um dos espécimens, concluímos que as diferencas entre êles não são suficientes para justificar a distinção específica.

Tendo em conta, ainda, baseados no seu nequeno tamanho, que se trata provàvelmente de formas jovens. nos parece mais acertado considerá-los como pertencendo a uma única espécie.

De acôrdo com Treadwft.l (1921. n. 86-88). I. nntata Fhlers seria uma esnécie distinta de $L$. ninetta. $\mathrm{N}_{\text {ศ }}$ reslidade. sua descrição não se anlica a nenhuma das duas espécies. Seus esnécimens, provenientes da Tamaira tem antenas "a trifle loncer than the nrostomium" a olhos reniformes (b. 87). anroximando-se muitn mais de L. collaris Grube (vide DAY. 1967. fio. $17.8-$ a).

Seoundo HARTMAN (1956. n. 984) I. collaric (= L. sulcate Treadwell. 1091). sonherida nrinci. nalmente do Pacífico e do f́ndico. ocorre também nas Antilhas.

Rullier menciona a ocorrência dessa esnécie nas Thas do Cabo Verde e na Guiné Franrêsa (1964, p. 181).

f́. nrovável que as duas esnéries. I. ninettr e I. collaris ocorram na costa brasileira. Porém. como dicsemos no início, o nosso material nos narece insuficiente nara um estudo comparativo, aue nermita comprovar essa hipótese.

Distribuicão - L. ninetta é conhecida do Atlântico. Mediterrânen. fndico e Parífico (Rultrier. 1964): África do Sul (DAY. 1967). Sua ocorrência na costa hrasileira (Abrolhos) foi referida nor Augener (1931). Os exemplares atuais provém da costa dos Estados de Alagoas e Sergipe.

Gênero Marphvsa Ouatrefages 1865 Marphvsa regalis Verrill 1900

(Fig. 63-68)

Marphvsa regalis Verrill. Treadwell. 1921, p. 66-69, fig. 224-234; est. 5, fig. 9-12. 1939, p. 256-258, fig. 75 .
Marphysa regalis Treadwell, 1911, p. 2-5, fig. 1-7.

? Nausicaa minima Hansen, 1882, p. 8, est. 2, fig. 22-25.

? Marphysa hentscheli Augener, 1931, p. 290-292, fig. 3 .

10 fragmentos anteriores (AK 04, BAC; AK 37, BAC; AK 45, BAC; AK 48, BAC (2); AK 49, BAC (2); $\mathrm{AK} 64, \mathrm{BAC}$ e $\mathrm{AK} 88, \mathrm{BAC})$, o maior dos quais com cêrca de 120 setígeros, medindo $70 \mathrm{~mm}$ de comprimento.

Descrição - Espécie medianamente robusta; corpo longo, de secção elíptica. Prostômio profundamente bi-lobado, com dois olhos conspícuos. Antenas subuladas, lisas; a mediana cêrca de duas vêzes mais longa que o prostômio. Pés da região anterior com cirro dorsal longo, subulado e cirro ventral piriforme. Cerdas simples, com limbo estreito e compostas, com haste robusta e artículo falciforme.

Brânquias a partir do $20 .^{\circ}-27 .^{\circ}$ setígero, constituídas por 1-5 filamentos muito longos; sub-pectinadas, onde melhor desenvolvidas (Fig. 64 a 66).

Cerdas pectinadas, com dentes numerosos e longos processos laterais, aparecem após o $30 .^{\circ}-40 .^{\circ}$ setígero. Ganchos sub-aciculares quase retos, com um dente accessório rudimentar, a partir do $20 .^{\circ}$ setígero.

Aparêlho bucal curto e robusto: forceps largo; maxila II com 3 e 4 dentes relativamente longos; maxilas III e IV em placas curvas, irregularmente denteadas (Fig. 67).

Mandíbula com duas peças estreitas, soldadas no têrço anterior; com expansões laterais laminares e o bordo cortante incrustado de calcário (Fig. 68).

Discussão - Os nossos exemplares, considerados como Marphysa regalis Verrill, correspondem perfeitamente à descrição de Treadwell (1911). Peculiaridades como a forma dos cirros parapodiais, das brânquias e das mandíbulas são idênticas às da espécie de Verrill. A singular saliência da face inferior do cirro dorsal dos segmentos anteriores (fig. 225 e 226), que poderia ser interpretada como uma anomalia ou defeito de preparação, é constatada também nos espécimens atuais (Fig. 64).

Marphysa atlantica (Kinberg), da Argentina, assemelha-se a esta espécie, quanto à posição da 1 . $^{\mathrm{a}}$ brânquia e à forma das cerdas; porém é insuficientemente caracterizada. A mesma circunstância ocorre em relação a $M$. minima (= Nausicaa minima Hansen), do Rio de Janeiro.

Quanto a $M$. hentscheli Augener, de Pernambuco, consideramos a descrição de Augener (baseada n'um único exemplar) insuficiente para bem caracterizar a espécie. Augener não-menciona as características do aparêlho bucal e a única diferença possìvelmente significativa consiste no aparecimento mais 
precoce das brânquias (no $17 .^{\circ}$ setígero, em hentscheli). Porém, mesmo êsse carácter é inexpressivo, pois Treadwell (que admite a identidade entre a sua Marphysa fragilis e $M$. regalis) menciona, explicitamente $(1911$, p. 3): "Gills begin on somites 16 to 19".

Parece-nos óbvio que Augener não examinou a descrição de $M$. fragilis, na qual Treadwell dedica um parágrafo à forma e distribuição das brânquias (p. 3 e 4$)$.

Distribuição - Bermudas (Hartman 1956); Antilhas; Nordeste do Brasil (Alagoas).

\section{Marphysa stylobranchiata Moore 1909}

Marphysa stylobranchiata Moore, 1909, p. 249-251, est. 7 fig. 8-12. Hartman, 1944a, p. 127-129. 1961, p. 84 . 1968 , p. 735,3 figs.

4 fragmentos anteriores (AK 31, BAC; AK 95, ACL e AK 102, L+D), o maior dos quais com 73 setígeros, medindo $55 \mathrm{~mm}$ de comprimento.

Descrição - Espécie medianamente robusta. Corpo rígido e de secção elíptica na região anterior; comprimido e flexível, na região branquial. Prostômio arredondado, com pequena reentrância no bordo anterior. Antena mediana duas vêzes mais longas que o prostômio; antenas laterais externas alcançando metade do comprimento da mediana. Olhos pequenos, inconspícuos.

Cirros dorsais dos segmentos anteriores e medianos, longos e subulados.

Brânquias constituídas por um único filamento cilíndrico, a partir do $200^{\circ}-22 .^{\circ}$ setígero; alcançando seu comprimento máximo entre o $30 .^{\circ}$ e $60 .^{\circ}$.

Cerdas compostas falcigieras, bi-dentadas. Acículos negros, em número de 2-3 por pé.

Discussão - Marphysa stylobranchiata Moore é caracterizada pelas brânquias unifilares, longas e presentes em todos os segmentos medianos e posteriores.

Nem um dos nossos exemplares, acima mencionados, é completo. Por essa razão, não pudemos apreciar as características dos segmentos caudais. Entretanto, da Est. 102 proveio também um longo fragmento com cêrca de 150 setígeros, dotado de brânquias e de cerdas semelhantes às de $M$. stylobranchiata. Nesse fragmento constituído presumivelmente pela região mediana e posterior, o pigídio tem dois uritos longos, subulados e dois processos ventrais curtos, claviformes. As brânquias dos últimos 80-100 segmentos são largas e achatadas, mais curtas que o cirro dorsal (novamente longos nesta região).

Distribuição - Marphysa stylobranchiatu era conhecida apenas da costa pacífica (Califórnia); a ocorrência atual estende a sua distribuição até o Nordeste do Brasil (Alagoas).

\section{Gênero Palola Gray 1847}

Palolo Gray. Hartman, 1938, p. 98.

Eunice (Palolo) Gray. Day, 1967, p. 382.

Palola Gray. Hartman, 1944a, p. 130. 1968, p. 707.

Palola siciliensis (Grube) 1840

Eunice siciliensis Grube. Fauvel, 1923, p. 405-407, fig. 159 e-m.

Eunice (Palolo) siciliensis Grube. Day, 1967, p. 382, fig. 17.2, a-f.

? Leodice cariboea. Treadwell, 1921, p. 47-49, fig. 136-143.

Palola siciliensis (Grube). Hartman, 1944a, p. 131. 1951, p. $57-58$.

6 fragmentos anteriores (AK 22, BAC; AK 31, BAC; AK 48, BAC; AK 72, BAC; AK 73, L e AK $100, R)$, o maior dos quais com cêrca de 130 setígeros, medindo $52 \mathrm{~mm}$ de comprimento.

Descrição - Os exemplares de Palola siciliensis desta coleção, tem proporções consideràvelmente menores que as mencionadas por FAUvel (1923) podendo-se admitir que alcançariam, se completos, apenas $80-100 \mathrm{~mm}$.

Exceto quanto ao tamanho, correspondem perfeitamente às descrições de Fauvel e de Day.

Corpo longo, de secção cilíndrica e rígido, na região anterior; comprimido e afilado na região mediana e posterior. Prostômio ligeiramente fendido; antenas lisas ou corrugadas (no material fixado), pouco mais longas que o prostômio; dois olhos grandes, negros, entre as antenas laterais. Cirros tentaculares lisos, tão longos quanto as antenas externas.

Aparêlho bucal caracterizado pelas proporções excepcionais das mandíbulas, que são muito mais longas e mais largas que o conjunto de maxilas, com os bordos externos recurvados para cima, com a forma de calha.

Maxilas curtas e robustas, de côr escura, com o suporte do forceps largo e proporcionalmente longo. Maxilas II com 3 dentes de cada lado, articulando-se perfeitamente quando fechadas.

Cirros dorsais longos, cilíndricos; cirros ventrais piriformes. Brânquias constituídas por um único filamento longo e subulado, presentes apenas na parte posterior do corpo, aparecendo aproximadamente no $100 .^{\circ}$ setígero.

Cerdas ùnicamente de dois tipos: capilares e compostas bi-dentadas; acículos negros, proeminentes, em número de um ou dois em cada pé.

Discussão - Hartman (1944a) distinguiu Palola siciliensis de $P$. paloloides Moore, pela presença, nesta última, de um $3 .^{\circ}$ dentículo na maxila II. En- 
tretanto, sua figura (de $P$. pallidus Hartman, 1938; sinônimo de $P$. paloloides, como reconhecido pela autora) é inexpressiva. Em oposição, a figura de $E$. siciliensis de FAUVEL (1923, p. 406) é singularmente clara e mostra uma das maxilas II com 3 dentes cons. pícuos.

A diferença essencial entre as duas espécies esta. ria na forma das brânquias; estas, sempre simples em siciliensis, são ramificadas, com 6.7 filamentos, em paloloides (HaRTMan, 1968, p. 737 menciona êsse carácter; porém sua fig. 4 , mostra um único filamento longo).

Os nossos exemplares, ainda que de pequeno porte e incompletos, exibem caracteres que os identificam, com razoável certeza, como pertencentes à espécie de Grube. Ainda que seja possível, não nos parece provável tenham as brânquias dos segmentos posteriores, características diversas das que pudemos examinar.

Distribuição - P. siciliensis (Grube) ocorre no Atlântico tropical (Gôlfo do México e África ocidental), no Mediterrâneo, Índico e Pacífico ocidental (DAY, 1968). A ocorrência atual estende sua distribuição até o Nordeste brasileiro (Alagoas).

Família LUMBRINERIDAE Malmgren 1867

Gênero Lumbrineris Blainville 1828

Lumbrineris cingulata Treadwell 1917

Lumbrineris cingulata Treadwell, 1921, p. 97-98, fig. 351-356; est. 7, fig. 1-9.

non: Lumbrineris cingulata Ehlers, 1897.

1 exemplar incompleto (AK 02, ACL) com cêrca de 60 setígeros, medindo $26 \mathrm{~mm}$ de comprimento.

Descrição - Prostômio curto, oval, sem olhos. Cerdas compostas falcígeras, do $1 .^{\circ}$ ao $17 .^{\circ}$ setígero; substituídas por ganchos simples, encapuzados, a partir do $18 .^{\circ}$ Acículos amarelos, robustos, em número de 2-3 em cada pé. Peças bucais bem conformadas, de côr castanho escuro; maxilas: I (forceps) longa e relativamente delgada; II com 5 dentes bem recortados; III com 3 dentes à esquerda e 2 à direita; IV com dois dentes de cada lado. Mandíbula alongada, translúcida, com a extremidade anterior larga, com sulcos semi-circulares paralelos.

Discussão - Os caracteres mais evidentes do nosso exemplar único coincidem com os de $L$. cingulata Treadwell.

A espécie é muito próxima de $L$. inflata Moore e de L. albifrons (Crossland), diferindo apenas pelo número de dentes da maxila III.

Hartman (1944a, p. 160) considera albifrons como sinônimo de inflata e admite que também cingulata possa ser idêntica a essa espécie.

DAY (1967, p. 435), também considera L. albifrons (Crossland) (1924, p. 50-55) descrita do Cabc da Boa Esperança, como sinônimo de inflata.
Preferimos, entretanto, considerar L. cingulata Treadwell como forma atlântica, mantendo-a como espécie válida.

Distribuição - L. cingulata era conhecida das Bermudas, Tortugas e Jamaica (Treadwell, 1921), e a ocorrência atual estende a sua distribuição até o Nordeste do Brasil (Alagoas).

\section{Lumbrineris cf. cruzensis Hartman 1944}

Lumbrineris cruzensis Hartman, 1944a, p. 165-166, est. 12, fig. 263-269.

1 exemplar incompleto (AK 36, BAC) com 40 setígeros e medindo cêrca de $11 \mathrm{~mm}$ de comprimento.

Descrição - Espécie pequena e delicada. Prostômio curto, globóide. Cerdas limbadas e ganchos compostos, do $1 .^{\circ}$ ao $10 .^{\circ}$ setígero; cerdas limbadas e ganchos simples, a partir do $11 .^{\circ}$. Acículos amarelos, em número de 1-3 em cada pé. Lóbulos post-setais dos segmentos anteriores, longos, triangulares.

Maxilas pretas, robustas; maxila II com 4 dentes de cada lado; maxilas III e IV com um único dente.

Discussão - $\mathrm{O}$ exemplar coincide razoàvelmente bem com a descrição original de Hartman. As cerdas e ganchos parecem mais robustos que os figurados pela autora e a substituição dos ganchos compostos é mais precoce - no $11 .^{\circ}$ setígero, em lugar do $16 .^{\circ}$ - Porém, as maxilas são muito semelhantes, assim como a forma arredondada do prostômio.

Sendo o exemplar único e incompleto, a identificação é feita com alguma reserva.

Distribuição - L. cruzensis era conhecida da Califórnia; a ocorrência atual, se confirmada, estende sua distribuição até o Nordeste do Brasil (Alagoas).

\section{Lumbrineris latreilli Audouin \& Milne Edwards} 1834

Lumbriconereis latreilli Aud. \& M. Edw.. Crossland, 1924, p. 10-15, fig. 8-14.

Lumbrineris latreilli Aud. \& M. Edw.. Hartman, 1944 a, p. 158, est. 9, fig. 213-216. Nonato, 1966, p. 70-71. Hartman, 1965 , p. 118-119.

1 exemplar incompleto (AK 64, ACL) com 32 setígeros, medindo $20 \mathrm{~mm}$ de comprimento e cêrca de $5 \mathrm{~mm}$ de maior diâmetro.

Descrição - Espécie robusta, como evidencia o pequeno fragmento. Prostômio cônico, de secção elíptica, desprovido de antenas e de olhos. Parapódios da região anterior curtos, com lóbulo post-setal de comprimento moderado, com 3 acículos amarelos.

Segmentos anteriores, até o $27 .^{\circ}$, dotados de cerdas compostas, falcígeras encapuzadas e cerdas simples, limbadas. A partir do $28 .^{\circ}$ setígero as cerdas 
compostas são substituídas por ganchos simples, robustos e igualmente encapuzados.

Maxilas negras; forceps robusto e liso; suportes curtos, incisados lateralmente; maxila II com 4 dentes bem recortados; maxila III com 2 dentes; maxila IV com 1 dente.

Mandíbulas de côr clara, a parte anterior marcada por linhas curvas concêntricas; parte basal larga, incisada em "V".

Discussão - L. latreilli Aud. \& M. Edw. se distingue de suas congêneres pelas proporçôes geralmente robustas e pela presença de cerdas compostas falcigeras nos setígeros anteriores.

Lumbrineris nasuta (Verrill), conforme a redescrição de Treadwell (1921, p. 101-102, fig. 371-377), é pràticamente indistinguível de L. latreilli.

Distribuição - A espécie é considerada amplamente cosmopolita. $\mathrm{Na}$ costa brasileira já havia sido constatada a sua presença, no Rio Grande do Sul (Nonato 1966, p. 71).

\section{Lumbrineris treadwelli Hartman 1942}

Lumbrineris treadwelli Hartman, 1956, p. 253, 268 e 288.

Lumbrineris maculata Treadwell, 1901. 1921, p. 103-104, fig. 378-385; est. 8, fig. 10. Hartman, 1942, p. 119-120, fig. 11, h e 14, d-e.

1 exemplar incompleto (AK 69, A) com 72 setígeros e medindo $58 \mathrm{~mm}$ de comprimento.

Descrição - Espécie medianamente robusta. Prostômio largo, oval, com manchas de pigmento dispostas irregularmente, na base. Parapódios anteriores longos, com lóbulos setais conspícuos. Setígeros anteriores, até $53 .^{\circ}$, com cerdas limbadas e ganchos sim. ples. A partir do $54 .^{\circ}$ setígero, desaparecem as cerdas limbadas, subsistindo apenas ganchos simples, robustos, em número de 2 e 3 em cada pé e o ló. bulo post-setal torna-se mais longo e estreito.

Peças bucais negras, muito robustas: forceps maciço, com base larga; maxila II simétrica, com 4 dentes bem recortados; maxila III e IV também simétricas, respectivamente com 2 e 1 dente. Mandíbulas longas, com o bordo anterior calcificado.

Discussão - O exemplar, ainda que incompleto, corresponde bem à descrição de $L$. maculata Treadwell; as proporções dos ganhos dos setígeros anteriores e dos setígeros posteriores são semelhantes às das figuras 381 e 383 de TrEadwell (1921) e as características das peças bucais também coincidem com as das figuras 384 e 385 .

O nôvo nome, L. treadwelli, foi proposto por Hartman, em 1965. Já em 1942, a autora, havia cons. tatado que o nome específico estava pré-ocupado (por espécies do gênero Arabella) e, nessa ocasião, não julgou necessário substituí-lo.
Distribuição - Lumbrineris treadwelli era conhecida apenas de Pôrto Rico e da Flórida; a ocorrência atual estende sua distribuição até o Nordeste do Brasil (Alagoas).

\section{Família ARABELLIDAE Hartman 1944 \\ Gênero Notocirrus Schmarda 1861 \\ Notocirrus cf. lorum Ehlers 1897}

Notocirrus lorum Ehlers, 1897, p. 78-80, est. 5, fig. 125-128. Hartman, 1964, p. 125, est. 39, fig. 2-5.

2 exemplares incompletos (AK 83, D e AK 85, BAC) respectivamente com cêrca de 100 e 50 setígeros anteriores, o maior medindo $72 \mathrm{~mm}$ de comprimento.

Descrição - Corpo longo e delgado, com seg. mentos muito numerosos. Prostômio relativamente curto, ovalado; com 4 olhos dispostos em linha, na margem posterior. Parapódios pouco desenvolvidos, com um lóbulo post-setal triangular, curto; cerdas de um único tipo, limbadas, com a lâmina curta, fortemente geniculada, denteadas na face convexa. Um ou dois acículos proeminentes, com a extremidade ligeiramente aguçada e envolta por uma "coifa" trans. parente.

Maxilas negras, robustas, com 2 peças basais ("suportes"), estreitas, muito longas e uma terceira, larga e translúcida, mais curta. Maxila I ligeiramente assimétrica; denteada em tôda a extensão, com o dente distal longo e recurvo. Maxila II fortemente assimétrica: a peça esquerda é muito mais longa, com cêrca de 15 dentes. Maxilas III e IV semelhantes entre si, com um longo dente distal quase reto. Maxila $\mathrm{V}$ constituída por um único dente longo, falciforme.

Mandíbulas largas, inteiramente negras, em forma de "H".

Discussão - Notocirrus lorum Ehlers assemelha-se a $N$. californiensis Hartman; distinguindo-se dêste pelo prostômio mais curto e arredondado; pelas maxilas com dentes muito mais numerosos, mandíbulas proporcionalmente mais curtas e mais largas e, ainda, pelas cerdas e acículos aparentemente mais delicados.

Quanto a Aracoda virginis Kinberg, da Patagonia, é, indubitàvelmente um Notocirrus; porém consideramos a descrição insuficiente para uma comparação mais acurada.

KINBERg (1910, p. 49-50 e est. 19) não descreve nem figura as peças bucais; porém menciona a inexistência de olhos ("oculi nulli"), carácter que, por si só, não nos parece fidedígno.

Distribuicão - Notocirrus lorum, descrito do Estreito de Magalhães, tem sido encontrado em diferentes pontos do litoral sul do Brasil, até o Rio de Janeiro (observação não publicada). A ocorrência atual estende sua área de distribuição até o Nordeste (Alagoas). 
Família DORVILLEIDAE Chamberlin 1919

Gênero Dorvillea Parfitt 1866

Dorvillea cf. moniloceras (Moore) 1909

Stauronereis moniloceras Moore, 1909, p. 256-259, est. 8, fig. 24-29. Hartman, 1968, p. 821, 6 figs.

1 exemplar incompleto (AK 18, BAC) com cêrca de 40 setígeros, medindo $11 \mathrm{~mm}$ de comprimento.

Descrição - Prostômio curto, globóide, com 4 olhos grandes; papila nucal inconspícua. Palpos robustos, recurvos, mais longos que as antenas; estas são moniliformes e relativamente curtas.

Cirros dorsais articulados, com a parte distal curta e ovalada; cirro ventral digitiforme. Cerdas superiores (supra-aciculares) simples, largas e com o bordo serrilhado; cerdas inferiores compostas, falcígeras, bi-dentadas. A espécie é desprovida de cerdas furcadas. Peças bucais do tipo característico para o gênero.

A pigmentação, no exemplar descorado, é indistinta.

Discussão - Dorvillea moniloceras (Moore) pertence ao grupo de espécies desprovidas de cerdas furcadas. A êsse grupo pertence também D. sociabilis (Webster) 1879. As duas são muito próximas, sendo admissível que moniloceras constitua apenas a forma pacífica de $D$. sociabilis.

Excetuadas diferenças de pigmentação, às quais não acreditamos poder atribuir maior importância, as duas espécies referidas distinguem-se, essencialmente, pelas proporções diferentes dos artículos das antenas e dos cirros dorsais.

Havendo examinado, recentemente, vários exemplares de D. sociabilis da costa do Estado de São Paulo, pudemos constatar que a variabilidade nas proporções dos artículos não só das antenas e cirros, como também das cerdas compostas, torna precária a distinção entre moniloceras e sociabilis.

D. grubei (Kinberg) 1865, descrita do Brasil, é insuficientemente conhecida e Hartman não a discute em sua revisão dos tipos de Kinberg (1949).

Distribuição - D. moniloceras (Moore) era conhecida da Califórnia e Hawai (Hartman. 1968). D. sociabilis (Webster) ocorre na costa atlântica dos Estados Unidos, até Carolina do Norte (Hartman, 1945) e. como se disse acima, foi coletada no Brasil, no litoral de São Paulo. Na costa nordeste (Alagoas) a ocorrência é inédita.

\section{Família ORBINIIDAE Hartman 1942 \\ Gênero Scoloplos Blainville 1828}

Scoloplos agrestis sp. nov. (Fig. 69-77)

2 exemplares incompletos (AK 151, L-A e AK 179 , L) com 30 e 26 segmentos anteriores, medindo respectivamente 18 e $11 \mathrm{~mm}$.
Diagnose - Tórax com 15 setígeros; brânquias a partir do $1 .^{\circ}$ segmento abdominal. Notopódios dos 9-10 últimos setígeros torácicos providos de algumas cerdas aciculares, retas e robustas e de raras cerdas capilares. Neuropódios abdominais providos ùnicamente de cerdas capilares.

Descrição - Corpo longo, de secção aproximadamente circular; região anterior ligeiramente alargada e comprimida. Prostômio longo, acuminado, sem olhos. 15 setígeros torácicos; brânquias lanceoladas, simples, a partir do $16 .^{\circ}$ setígero $\left(1 .^{\circ}\right.$ abdominal) (Fig. $69)$. Segmentos torácicos com um cirro dorsal digitiforme, bem desenvolvido a partir do $3 .^{\circ}$ setígero. Ramo dorsal com um feixe de cerdas capilares longas; ramo ventral dos 6-7 primeiros setígeros constituído por uma prega pouco elevada, com uma fileira de cerdas aciculares longas (Fig. 71 e 74). A partir do $7 .^{\circ}-8 .^{\circ}$ setígero, aparecem, no ramo ventral, $2-3$ cerdas aciculares, curtas e robustas e um pequeno feixe de cerdas capilares (Figs. 70-72 e 75). A transição para a região abdominal é abrupta, sendo já o $16 .^{\circ}$ setígero inteiramente diferenciado como segmento abdominal.

Segmentos abdominais caracterizados pela presença de brânquias erectas e ramos parapodiais conspícuos (Fig. 73). Brânquias sem franja de cílios. Notopódios com um cirro longo e um feixe delgado de cerdas capilares. Neuropódios dirigidos dorsalmente e com apenas algumas cerdas capilares, longas; cerdas furcadas não foram vistas. As cerdas capila. res, torácicas e abdominais, têm uma estriação escalariforme característica (Fig. 76-77).

Discussão - A forma do prostômio, das cerdas e das brânquias, aliada à ausência de franjas parapodiais e ventrais, caracteriza os nossos exemplares como legítimos Scoloplos.

Entretanto, a presença de grossas cerdas acicula. res, curtas, aguçadas e lisas ("soies en épieu" de Rullier), dispostas n'uma única fileira nos neuropódios torácicos, não se coaduna com os caracteres que distinguem os dois sub-gêneros aceitos como válidos. Ainda assim, o aparecimento tardio da $1 .^{\mathrm{a}}$ brânquia e a ausência de acículo proeminente nos neuropódios abdominais indica uma maior afinidade com o sub-gênero Scoloplos sensu stricto.

Scoloplos agrestis sp. nov. tem uma indubitável semelhança com $S$. madagascarensis FAUVEL (1919, p. 433-434) e $S$. robustas Rullier (1964, p. 1.090 . -1.092), espécies em que as brânquias aparecem nos últimos segmentos torácicos ou no $1 .^{\circ}$ abdominal e as cerdas neuropodiais do tórax são dispostas em apenas uma ou duas fileiras. Nestas, porém, a região torácica é constituída, respectivamente, por 26 a 27 e 21 setígeros e as cerdas aciculares dos neuropódios são muito mais numerosas.

É possível que os nossos espécimens sejam formas jovens, caracterizadas justamente pelo menor número de segmentos torácicos. Mesmo que essa hipótese seja correta, mantem-se a distinção, pois um 
exemplar de $S$. madagascarensis com apenas 17 setígeros torácicos, tinha brânquias a partir do $60^{\circ}(\mathrm{FAU}$ VEL, p. 434), o que indica uma independência entre o número de segmentos anteriores e a posição da $1 .^{2}$ brânquia,

Quanto a $S$. robustus, do qual se conhece apenas o exemplar tipo, o nosso material e o de Rullier nos parecem por demais exíguos para uma apreciação correta.

O tipo está depositado no Laboratório de Ciências do Mar, da Universidade Federal de Pernambuco.

Família CHAETOPTERIDAE Malmgren 1867

Gênero Mesochaetopterus Potts 1914

Mesochaetopterus sp.

1 exemplar incompleto e parcialmente macerado (AK 07, H).

Gênero Phyllochaetopterus Grube 1863

Phyllochaetopterus cf. gracilis Grube 1863

Phyllochaetopterus gracilis Grube. Fauvel, 1927, p. 88, fig. 31 , d-f.

1 exemplar incompleto (AK 139, D), parcialmente macerado.

Phyllochaetopterus gracilis Grube é conhecido das Ilhas Canárias e do Senegal, no Atlântico tropical.

Gênero Telepsavus Costa 1861

Telepsavus sp.

Numerosos fragmentos de tubos, vasios (AK 80, L; AK 170, L; AK 176, L e AK 179, L).

Telepsavus costarum Claparède, cujos tubos são semelhantes aos desta coleção, é espécie comum no litoral sul do Brasil, ocorrendo geralmente em profundidades de $0-50 \mathrm{~m}$ (observação não publicada).

Família CIRRATULIDAE Carus 1863

Gênero Tharyx Webster \& Benedict 1887

Tharyx sp.

? Tharyx setigera Hartman, 1945, p. 35-36, est. 7, fig. 1-3.

2 exemplares incompletos (AK 60, L), constituídos por cêrca de 60 setígeros anteriores, o maior medindo $10 \mathrm{~mm}$ de comprimento e com um diâmetro de $0,9 \mathrm{~mm}$.

Descrição - Corpo de secção aproximadamente circular, ligeiramente afilado na região anterior. Prostômio alongado, com dois grupos de manchas oculares minúsculas. Palpos não subsistem em nenhum dos dois exemplares, porém o seu ponto de inserção é aparente. Primeiro setígero com dois pares de cirros tentaculares ("brânquias"), um dos quais, muito delgado. Segmentos seguintes, até o $65 .^{\circ}$ (último do fragmento maior), providos ùnicamente de cerdas capilares largas (limbadas), geniculadas. Setígeros medianos com 7 a 9 cerdas no notopódio e 8-15 no neuropódio. Nos dois ramos, cerdas curtas alternam com cerdas muito mais longas.

As brânquias remanescentes são em pequeno número e mais freqüentes nos primeiros segmentos.

Côr, no álcool - Branco, amarelado.

Discussão - Tendo em conta as proporções dos dois fragmentos, o número de setígeros relativamente elevado indica uma espécie provàvelmente pequena. A presença de olhos e de cerdas de um único tipo, ao lado do pequeno tamanho, coincide com os caracteres de Tharyx setigera, descrita por Hartman, de Beaufort (North Carolina).

Esta espécie é próxima de Tharyx marioni (Saint-Joseph), distinguindo-se dela pela presença de olhos, pelo menor número de brânquias e pelo comprimento muito menor.

\section{Família FLABELLIGERIDAE Saint-Joseph 1894 Gênero Piromis Kinberg}

Piromis Kinberg. Hartman, 1961, p. 162. Day, 1961, p. 508-509. 1967a, p. 663.

As espécies dêste gênero assemelham-se externamente às de Pherusa Oken. Os órgãos bucais eversíveis consistem de um processo mediano, em forma de língua, no qual estão inseridos os tentáculos orais ("brânquias"). As cerdas notopodiais são delgadas, estriadas transversalmente e com a ponta inteira; as neuropodiais são simples, distalmente bífidas, ou, falcígeras, com a ponta inteira (HARTMAN, 1961, p. 122).

Hartman admite que os gêneros Semiodera Chamberlin, 1919 e Zorus Webster e Benedict, 1887, possam ser sinônimos de Piromis Kinberg e relaciona as espécies que devem ser incluídas neste último (p. 122-123).

\section{Piromis sp.}

(Fig. 78)

Brada villosa (Ratke). Luna, 1969.

1 exemplar completo (AK 12, BAC) com 55 setígeros, medindo $30 \mathrm{~mm}$ de comprimento.

Descrição - Corpo longo, fusiforme, com o maior diâmetro à altura do $100^{\circ}$ setígero; com papilas cilíndrico-clavadas, distribuídas irregularmente e não aglutinando areia. A superfície do corpo é sulcada por inúmeras pregas sinuosas e contíguas, recoberta por lôdo extremamente fino. $\mathrm{Na}$ face ven- 
tral, um par de aberturas (póros nefridiais?) no bordo anterior do $5 .^{\circ}$ setígero.

Os órgãos bucais, invaginados no exemplar, foram expostos por dissecção. Tubo oral curto, com margem pregueada; palpos longos e canaliculados, com bordos sinuosos. Brânquias cilíndricas, em feixe compacto; inseridas sôbre um processo dorsal em forma de língua triangular. Olhos não são aparentes. Cerdas tôdas simples e com ponta inteira; as dos três primeiros setígeros, longas e delgadas, dirigidas para a frente. Primeiro setígero apenas com cerdas dorsais. Os 4 setígeros subseqüentes têm cerdas notopodiais e neuropodiais do mesmo tipo, longas e estriadas transversalmente ("articuladas"); as ventrais muito mais grossas que as dorsais. A partir do $6 .^{\circ}$ setígero as neuropodiais são substituídas por cerdas aciculares robustas, falciformes (Fig. 78), em número aproximadamente constante, de 4 em cada pé; as notopodiais são semelhantes às dos segmentos anteriores, porém muito mais curtas.

Côr, no álcool - Amarelo-ferrugem; cerdas aciculares castanho-amarelado.

Discussão - O exemplar agora identificado como pertencendo ao gênero Piromis, havia sido, quando do exame inicial da coleção, considerado como Brada villosa (Ratke). A configuração geral, as características das cerdas e a presença de dois "póros" conspícuos, no $5 .^{\circ}$ setígero, coincidem com os caracteres mais evidentes dessa espécie. Os processos bucais, invaginados, não permitiam uma comparação mais minuciosa.

A dissecção, porém, revelou a presença de brânquias inseridas sôbre uma base única, lingüiforme; carácter êsse, peculiar ao gênero Piromis.

Os póros do $5 .^{\circ}$ setígero são, aparentemente, ligados a órgãos internos, presumivelmente nefrídios; porém a fragilidade das vísceras torna difícil o reconhecimento de sua natureza. As cerdas neuropodiais sigmóides e robustas, com ponta inteira, assim como a raridade das papilas, indicam uma possível identidade entre o exemplar atual e Piromis arenosus Kinberg.

As descrições dessa espécie mencionavam cerdas neuropodiais bífidas e articuladas em quase todo o seu comprimento. Porém, a descrição recente de DAY (1967a, p. 664) admite a existência, em exemplares da África do Sul, de cerdas pràticamente idênticas às do exemplar aqui estudado: “... setiger 3 has about six dorsal and five long stout setae ventrally, some of which may end in minute bidentate hooks. Thereafter all notopodia have four to six capillaries and all neuropodia have four to eight multiarticulate hooks (fig. 32.4, a-d) which end in either unidentate or bidentate tips".

A diferença no número de cerdas em cada pé pode ser atribuída ao maior desenvolvimento dos exemplares estudados por $\mathrm{D}_{\mathrm{AY}}$ (cêrca de 60 setígeros e até $90 \mathrm{~mm}$ de comprimento). O mesmo autor descreve (1961, p. 509) um pequeno espécimem de $\mathrm{Pi}$ romis sp., no qual "A thin film of mud and mucus forms a delicate coat, which covers the body" e "Neurosetae are 4-5 stout pseudo-compound hooks ending in falcate, uni-dentate blades". Esse exemplar, da África do Sul é, aparentemente idêntico ao nosso.

\section{Gênero Pherusa Oken 1807}

Pherusa Oken. Day, 1967a, p. 658.

Pherusa scutigera (Ehlers) 1887

(Fig. 79-83)

Stylarioides scutiger Ehlers, 1887, p. 165-168, est. 42, fig. 1-5.

? Stylarioides coronatus Ehlers, 1908, p. 121-123, est. 16, fig. 3-8.

Stylarioides sp. Luna, 1969.

1 exemplar completo (AK 139, D), com cêrca de 60 setígeros e medindo $28 \mathrm{~mm}$ de comprimento.

Descrição - Corpo longo, clavado, recoberto por papilas predominantemente curtas, triangulares, não aglutinando areia. Os três primeiros setígeros são largos, achatados; ligeiramente convexos na face ventral e recobertos por uma fina camada de areia na face dorsal. Região anterior prolongada por um longo tubo membranoso, translúcido. Cerdas dos 3 primeiros setígeros muito longas, iridescentes, formando uma gaiola cefálica. Uma espécie de "cintura" marca a transição entre os segmentos anteriores, comprimidos e a região posterior de secção aproximadamente cilíndrica. Do bordo dessa constrição se projetam, dirigidas para a frente, grossas papilas subuladas, muito longas (Fig. 80). A esta "coroa" de papilas, que é interrompida ventralmente, se sucedem séries transversais constituídas por papilas gradualmente menores e dispostas irregularmente.

A região que abrange os setígeros $4 .^{\circ}$ a $15 .^{\circ}$, é intumescida (condição aparentemente anormal), com pequenas papilas cônicas, esparsas.

Junto aos feixes de cerdas e particularmente conspícuas nos segmentos anteriores, agrupam-se 3-4 papilas cilíndricas e longas. $\mathrm{O}$ bordo anterior do lóbulo cefálico é, igualmente, provido de papilas cilíndricas.

Tôdas as cerdas dorsais e as ventrais dos 5 primeiros setígeros são capilares segmentadas (Fig. 81), características da família e distinguindo-se entre si, pelo tamanho. A partir do $6 .^{\circ}$ setígero as ventrais são substituídas por cerdas aciculares, relativamente curtas, muito robustas e com extremidade falciforme, lisa e inteira (Fig. 82). Nos setígeros da região posterior, as cerdas neuropodiais são tão robustas quanto as da região mediana, característica que as torna muito aparentes (Fig. 83).

Os segmentos da metade posterior do exemplar são uniforme e densamente recobertos por papilas triangulares, curtas.

Côr, no álcool - As papilas que recobrem a região mediana e posterior são amarelo-alaranjado; incrustação de areia pardo-amarelado; cerdas neuro- 
podiais com base castanha e extremidade amarelo. -dourado.

Discussão - A existência de uma constrição conspícua, na região anterior do corpo, foi considerada por CHAMBERLIN (1919, p. 397) como carácter peculiar ao gênero Therochaeta, por êle criado. Entretanto, o próprio autor parece ter atribuído maior significação às cerdas aciculares, descrevendo-as como pseudo-articuladas. O nome do gênero traduziria, precisamente, essa característica (p. 397, rodapé).

Até onde pudemos constatar, o nosso exemplar não possui cerdas pseudo-articuladas e, tão pouco, as encontrou Ehlers em seu Stylarioides scutiger.

É indubitável que a forma peculiar dos segmentos anteriores distingue Stylarioides scutiger e $S$. coronatus das demais espécies do gênero Pherusa, podendo justificar a criação de um nôvo gênero.

Hartman, porém (1965), mantém scutiger e coronatus no gênero Pherusa.

O exemplar aqui descrito, tem caracteres intermediários entre os das duas espécies de Ehlers acima mencionadas. Da primeira espécie só encontramos referência ao espécimem-tipo, coletado pelo "Blake" ao largo de Havana (Cuba). Da segunda também, aparentemente, são conhecidos apenas os exemplares coletados pela Deutschen Tiefsee Expedition (Estações "Valdivia" 202 e 258) na Indochina e na costa oriental da África.

A "coroa" incompleta, conseqüência da falta de papilas ventrais longas, é carácter de scutiger; enquanto a presença de cerdas neuropodiais falcadas, robustas, já no $6 .^{\circ}$ setígero (em lugar do $90^{\circ}$ ) é peculiar a coronatus.

A distinção entre as duas espécies é precária. EHLERS (1908, p. 123) considera que o maior comprimento e o maior número de segmentos distingue coronatus de scutiger - "isto na suposição de que o exemplar de scutiger estava completo"; condição da qual o autor diz não ter duvidado.

Subsistiriam, assim, apenas diferenças na conformação dos segmentos anteriores; das quais o número e forma das grandes papilas que formam a "coroa", nos parece a mais significativa.

Uma eventual diferença nas cerdas neuropodiais dos últimos segmentos, que em nosso exemplar são particularmente robustas, como as mencionadas por EHLers (p. 122) para coronatus, também só teria valor quando constatada em espécimens realmente completos.

Quanto a Stylarioides collarifer Ehlers, coletado também pelo "Blake" na mesma área e posteriormen. te encontrado na Califórnia, Flórida e New England (HARTMAN, 1965, p. 180, est. 40; como Therochaeta collarifera) se distingue dos acima mencionados, pela presença de cerdas aciculares pseudo-articuladas e pelo menor número de setígeros (cêrca de 24) e seu tamanho reduzido $(12,5$ a $16,4 \mathrm{~mm})$.

Distribuição - As referências se limitam à ocorrência original - Antilhas (Cuba) e, agora, Nordeste do Brasil (Sergipe).
Família OPHELIIDAE Malmgren 1867

Gênero Armandia Filippi 1861

Armandia cf. agilis (Andrews) 1891

Ophelina agilis Andrews, 1891, p. 289, est. 15, fig. 21-26 e 28.

Armandia agilis (Andrews). Hartman, 1942, p. 129, fig. 12, c-d. 1951, p. 97 . Reunad, 1956, p. 30 .

-31 , fig. 20.

Ammotrypane sp. Luna, 1969.

1 exemplar completo (AK 185, D-L), medindo $56 \mathrm{~mm}$ de comprimento.

Descrição - Corpo longo e robusto, com 59 setígeros. Prostômio curto, acuminado, com pequeno palpódio. Brânquias a partir do $2 .^{\circ}$ setígero até o $52 .^{\circ}$; largas e espêssas, com pequenas manchas de pigmento, irregularmente distribuídas. Lóbulos pré-setais (cirros dorsais?) dos segmentos anteriores bem desenvolvidos, triangulares; lóbulos post-setais minúsculos, em forma de papila. Os quatro últimos setígerns com parapódios rudimentares, aquetas. 20 pares de olhos laterais, o primeiro entre os segmentos $7 .^{\circ}$ e $8 .^{\circ}$; os anteriores maiores, oblongos e os demais, pequenos e de contôrno irregular.

Tubo anal largo, com o bordo franjado por cêrca de 20 papilas cilíndricas semelhantes entre si. $O$ cirro anal falta neste exemplar.

Discussão - Armandia agilis é, no gênero, uma das espécies que alcança maiores proporções e número mais elevado de segmentos. A descrição original de Andrews, de material da Carolina do Norte, não menciona olhos laterais; porém a sua existência (em número de 11 pares) foi constatada por Hartman, nos exemplares depositados no U.S. National Museum (1942) e em outros da mesma procedência (1945).

O nosso espécimem aproxima-se mais dos exemplares do Gôlfo do México, estudados por Hartman (1951) e Renaud (1956) e que possuem 20 a 21 pares de olhos laterais.

Distribuição - North Carolina (Beaufort), Gôlfo do México (Flórida, Bimini) e Nordeste do Brasil (Sergipe).

\section{Armandia maculata (Webster) 1884}

(Fig. 84-85)

Ophelina maculata Webster, 1884, p. 322, est. 11, fig. 54-55.

Armandia maculata (Webster). Hartman, 1942, p. 129-130, fig. 14, a.

5 exemplares completos (AK 15, BAC; AK 26, H; AK 50, ACL; AK 63, ACL e AK 68, ACL), medindo 20-28 $\mathrm{mm}$ de comprimento. 
Descrição - Forma pequêna, delicada, com 29 setígeros. Prostômio cônico, afilado, com um pequeno palpódio e 3 olhos minúsculos. Cerdas do $10^{\circ}$ setígero maiores que as dos seguintes e com brilho metálico. Brânquias longas e estreitas, ciliadas; bem desenvolvidas do $2 .^{\circ}$ ao $26 .^{\circ}$ setígero e rudimentares ou ausentes nos 3 últimos. 11 pares de olhos laterais, de tamanho uniforme; o primeiro entre os setígeros $6 .^{\circ}$ e $7 .^{\circ}$ Tubo anal relativamente curto, fendido ventralmente e franjado por $18-20$ papilas cilindricas, das quais as duas anteriores mais robustas, clavadas (Fig. 85).

Discussão - Armandia maculata distingue-se de A. polyophthalma Kükenthal pelo número menor de segmentos e de olhos laterais e, ainda pelo tubo anal fendido ventralmente. A constância do número de segmentos e de olhos foi verificada em cêrca de uma centena de exemplares da região de Ubatuba, S.P. (ainda não publicado)

Distribuição - A. maculata era conhecida apenas das Bermudas; a ocorrência atual, no Nordeste do Brasil (Alagoas), parece ser a primeira referida para o Atlântico Sul.

\section{Armandia polyophthalma Kükenthal 1887}

Armandia polyophthalma Kükenthal. Fauvel, 1927, p. 135-136, fig. 48, a-e.

1 exemplar completo (AK 75, ACL), medindo $30 \mathrm{~mm}$ de comprimento.

Descrição - Corpo longo, afilado nas duas extremidades; goteira ventral e pregas laterais profundas. Prostômio cônico, agudo, terminando por um palpódio cilíndrico e curto. Brânquias liguladas e longas, a partir do $2 .^{\circ}$ setígero, até a extremidade posterior. 23 pares de olhos laterais; o primeiro entre os setígeros $5 .^{\circ}$ e $6 .^{\circ}$ e o último entre o $27 .^{\circ}$ e $28 .^{\circ}$, sendo os 15 primeiros maiores que os demais. Os 5 últimos setígeros caracterizam-se pelo grande desenvolvimento dos parapódios e das cerdas que são robustas, muito longas e com brilho metálico. Tubo anal não fendido, com 12 papilas, sendo as duas ventrais medianas, grossas e claviformes. Cirro anal único e muito longo.

Os órgãos nucais e a tromba estão invaginados neste exemplar.

Discussão - O exemplar de Armandia polyo. phthalma desta coleção corresponde bem à descrição de Fauvel. O desenvolvimento maior dos últimos setígeros, o número de segmentos e de olhos laterais, assim como a forma e os apêndices do tubo anal, caracterizam suficientemente a espécie.

Distribuição - Mediterrâneo e Atlântico Norte. A. cirrosa Filippi, que talvez seja uma forma jovem de A. polyophthalma (FAUveL, 1927, p. 136) ocorre no Mediterrâneo e na Ilha da Madeira. A ocorrência atual, no Nordeste do Brasil (Alagoas), parece ser a primeira referida para o Atlântico Sul.
Armandia sp.

(Fig. 86)

? Armandia nonpapillata Jones, 1962, p. 191-192, fig. 83-90.

1 exemplar completo (AK 173, L) medindo 20 mm de comprimento.

Descrição - Corpo curto, lateralmente comprimido, com 30 setígeros. Prostômio curto, com palpódio e 3 olhos minúsculos. Primeiros segmentos com uma "crista" dorsal que se estende até a extremidade do prostômio (Fig. 86). Brânquias presentes, do $2 .^{\circ}$ ao $27 .^{\circ}$ setígeros, longas e estreitas, ciliadas. $11 \mathrm{pa}$ res de olhos laterais; o primeiro entre os setígeros $6 .^{\circ}$ e $7 .^{\circ}$. Tubo anal relativamente curto e fendido ventralmente, sem papilas de qualquer espécie.

Discussão - O nosso exemplar assemelha-se a Armandia maculata (Webster), distinguindo-se desta pela forma do prostômio e pelo tubo anal desprovido de papilas.

Distingue-se de $A$. nonpapillata Jones, descrita da Jamaica, apenas pelo prostomio muito curto, pois a crista dos primeiros segmentos pode ser uma conseqüência da fixação.

A ausência de papilas no tubo anal, especialmente quando constatada em apenas um espécimem, não nos parece carácter idôneo para distinção específica. Não só tais apêndices podem ser perdidos com relativa facilidade, como, ainda, é admissivel a ocorrência de um exemplar imperfeito.

Gênero Ophelia Savigny 1818

Ophelia formosa (Kinberg) 1866

Cassandane formosa Kinberg, 1866. 1910, p. 66, est. 25, fig. 6 .

Ophelia formosa (Kinberg). Hartman, 1948, p. 114. -115. Tebble, 1953, p. 362 e 365.

2 exemplares completos (AK 19, A e AK 79, ACL) com 41 segmentos, medindo 55 e $35 \mathrm{~mm}$.

Descrição - Corpo fusiforme, alongado; extremidade anterior acuminada; pigídio com duas grossas papilas ventrais e um círculo de papilas dorsais curtas. Pregas laterais espêssas, estendendo-se ao longo da região branquial, até o pigídio. 41 setígeros, dos quais 26 medianos, com brânquias. Poros nefridiais nos setígeros 12 a 17 . Setígeros 13 a 23 com fileiras transversais de poros minúsculos ("fenestrações branquais") até aproximadamente a metade de sua altura. Pregas dorsais estreitas e altas, nos 5 últimos setígeros. Brânquias largas, com o bordo pregueado.

Côr, no álcool — Branco leitoso, uniforme.

Discussão - Tebble (1952, p. 557) propôs um código, a que chamou "fórmula do corpo", para indicar a disposição dos segmentos e apêndices no gênero Ophelia. Essa fórmula, completada com dados sôbre a presença de fenestrações branquais ("branchial fenestrations", TebBle, 1953, p. 364) e as ca- 
racterísticas do pigídio, permite uma comparação relativamente fácil entre as espécies. A diagnose de $O$. formosa Kinberg é expressa pela fórmula: $9 a+$ $+26 b(3 b-8 b)+6 a=41$, onde $3 b-8 b$ indica a posição dos poros nefridiais nos segmentos medianos.

Ophelia formosa assemelha-se a $O$. africana Tebble (1953, p. 364-365) cuja fórmula, estabelecida pelo autor é $9 a+27 b+3 a+1 n=40$. Ambas têm 9 segmentos anteriores e papilas pigidiais semelhantes, além do número de segmentos quase idêntico (respectivamente 41 e 40 ).

DAY (1961 p. 513) baseando-se em três exemplares coletados também na África do Sul (Table Bay), redescreveu $O$. africana e considera o holótipo de Tebble como uma forma jovem, o que explicaria a ausência de fenestrações e de poros nefridiais. De acôrdo com a nova descrição, a fórmula do corpo de $O$. africana é: $9 a+28 b(3 b-8 b)+2 a+$ $+2 n=41$, com fenestrações em todos os segmentos branquiais. Day evidencia o fato de que tais caracteres colocam $O$. africana ainda mais perto de $O$. formosa Kinberg, do que se havia pensado, mas que, mesmo assim, podem ser distinguidas pelo número de segmentos posteriores desprovidos de brânquias: $6 \mathrm{em}$ formosa e apenas 2 em africana.

Distribuição - $O$. formosa foi descrita da Argentina. No Brasil foi coletada na região da Ilha Grande (Rio de Janeiro) e a ocorrência atual estende a sua distribuição até o Nordeste (Alagoas).

Família STERNASPIDAE Carus 1863

Gênero Sternaspis Otto 1821

Sternaspis capillata Nonato 1966

(Fig. 87-88)

Sternaspis capillata Nonato, 1966, p. 79-84, 9 figs.

2 exemplares completos (AK 152, A-L e AK 171, L) medindo $11 \mathrm{~mm}$.

Descrição - Corpo curto, elíptico, com um estrangulamento, bem marcado, entre a região anterior e a mediana; recoberto por finas partículas de lôdo e areia. Prostômio conspícuo; cerdas dos 3 primeiros setígeros numerosas, espatuladas, robustas e com brilho metálico. Papilas genitais longas, cilíndricas, incrustadas de areia, emergindo do $7 .^{\circ}$ setígero. Segmentos medianos providos de feixes de cerdas capilares minúsculas, dificilmente perceptíveis. Escudo central indiviso, com superfície rugosa, mas sem ornamentação aparente. Últimos segmentos recobertos por longas papilas filiformes. Brânquias robustas, pouco numerosas e não agrupadas em placa; no material fixado, a maioria enrolada em espiral (Fig. 87 e 88).

Os dois exemplares desta coleção assemelham-se, quanto ao tamanho, aos provenientes da costa de São Paulo.

Distribuição - Brasil, costa sul (São Paulo e Rio de Janeiro) e nordeste.
Família CAPITELLIDAE Grube 1862

Gênero Dasybranchus Grube 1850

Dasybranchus sp.

1 exemplar incompleto (CAN 121, ACL).

Família OWENIIDAE Rioja 1917

Gênero Owenia delle Chiaje 1844

Owenia fusiformis delle Chiaje 1844

Owenia fusiformis delle Chiaje. Fauvel, 1927, p. 203-204 , fig. 71, a-f. Day, 1967a, p. 649-651, fig. 31.1 , e-j.

Numerosos tubos com os animais, nas estações AK 39, A; 87, L; 94, A-L; 105, L; 150, L; 151, L-A; 161, L; 163. L; 164, L; 165, L; 167, L; 168, L; 169, L; 184, D; 186, D-L e 190, D.

Os tubos de Owenia, desta coleção, têm todos pequenas dimensões e são predominantemente fusiformes, com cêrca de $50 \mathrm{~mm}$ de comprimento e 1,5 a $2,2 \mathrm{~mm}$ de diâmetro. A incrustação externa é de grãos de areia mineral, com raros fragmentos orgânicos.

Um exemplar de cada estação foi retirado de seu tubo, para comparação. Exceto quanto ao tamanho, que varia entre 20 e $35 \mathrm{~mm}$, todos os animais são semelhantes e correspondem à descrição abaixo.

Descrição - Corpo cilíndrico, de diâmetro uniforme, com 18 a 30 segmentos; anteriormente truncado e com a região posterior comprimida, espatulada. Prostômio com uma coroa de 5-6 brânquias achatadas, laciniadas. Duas manchas oculares na base das brânquias.

Região torácica constituída pelo segmento bucal, aqueta e por mais 3 segmentos providos ùnicamente de cerdas dorsais, capilares. Os 5 primeiros segmentos abdominais muito longos; os seguintes, gradualmente mais curtos. Cerdas abdominais dorsais, capilares espinhosas; toros uncinígeros formados por numerosas fileiras, contíguas, de uncini sigmóides, minúsculos e com o rostro bi-dentado.

Distribuição - $O$. fusiformis, considerada espécie cosmopolita, é comum e abundante em fundos de areia ou cascalho de conchas, em tôda a costa sul do Brasil. Os exemplares atuais provém da costa dos Estados de Alagoas e Sergipe.

\section{Família PECTINARIIDAE Quatrefages 1865}

Vários fragmentos de tubos (AK 63, ACL e AK 92, A; CAN 122, BAC e CAN 126, BAC).

O grande diâmetro dos tubos de AK 63 e 92 (até $10 \mathrm{~mm}$ ) permite supor que se trate de tubos de Cistenides Malmgren.

Cistenides gouldii Verrill, com tubos semelhantes a êstes $(70 \mathrm{~mm}$, com um diâmetro de $11 \mathrm{~mm})$, foi coletado no litoral do Estado de São Paulo, em pro- 
fundidades de cêrca de $50 \mathrm{~m}$ (Ilha Vitória; ainda não publicado).

\section{Família AMPHARETIDAE Malmgren 1867 \\ Gênero Amphicteis Grube 1850}

Prostômio com um par de pregas glandulares divergentes. Tentáculos bucais lisos, com uma goteira longitudinal. Quatro pares de brânquias. 17 setígeros torácicos, dos quais 14 com uncini e 13 a 19 setígeros abdominais. Uncini com dentes dispostos n'uma única série vertical (cf. DAY, 1967).

\section{Amphicteis gunneri (Sars) 1835}

Amphicteis gunneri (Sars). Fauvel, 1927, p. 231, fig. 80 a-k. Day, 1967a, p. 695-696, fig. 35.2, g.n.

1 exemplar (parcialmente macerado - AK 169, L), com cêrca de $30 \mathrm{~mm}$ de comprimento.

Descrição - Prostômio com pregas glandulares salientes e com numerosas manchas oculares dispostas em linha transversal; tentáculos cilíndricos e lisos. Segmento paleal com dois feixes de cêrca de 25 cerdas muito longas, dispostas em léque. Quatro pares de brânquias, das quais são remanescentes apenas duas, relativamente largas e comprimidas; os pontos de inserção das demais indicados por "cicatrizes" elípticas, contíguas.

O número de segmentos abdominais não pôde ser determinado com certeza, devido ao estado precário da região posterior.

Discussão - Amphicteis gunneri (Sars) foi considerada por FAUveL \& RULLIER (1957, p. 381) como "uma espécie largamente cosmopolita, que vive igualmente bem nas águas glaciais, temperadas ou equatoriais, tanto na superfície quanto em grandes profundidades".

Parece-nos admissível, entretanto, que tal ecletismo seja apenas aparente. Diferenças no tamanho e número das páleas e na forma das brânquias, constatadas em exemplares de procedência diversa e muitas vêzes associados à caracteres menos conspícuos, indicariam que se trata, na realidade, de um conjunto de espécies muito próximas.

0 exemplar desta coleção, que identificamos com alguma reserva, se caracteriza pelo grande número e comprimento das páleas.

Distribuição - Atlântico norte, da Groelândia e Noruega até North Carolina; Marrocos, Ghana e África do Sul; Mediterrâneo; Indico, Kerguelen (DAY, 1967a), Togo e Dahomey, Pacífico, Mares Antárticos (Rullier, 1965). New England e extremo nordeste da América do Sul (Hartman, 1965). Nordeste do Brasil (Alagoas).
Família TEREBELLIDAE Malmgren 1867

Gênero Loimia Malmgren 1866

Loimia medusa (Savigny) 1820

Terebella medusa Savigny, 1820, p. 85.

Loimia medusa (Savigny). Fauvel, 1914, p. 145-146, est. 7, fig. 6-9. 1953, p. 416-418, fig. 218, a-f. Hartman, 1945, p. 45, est. 10, fig. 2-3. Day, 1967a, p. 743 , fig. 36.9 , a-c.

Loimia minuta Treadwell, 1929a.

Loimia montagui Grube. fide Fauvel, 1953.

Loimia turgida, 1891, p. 298, fig. 46-49.

2 exemplares incompletos (AK 40, ACL e AK 71, ACL), constituídos pela região anterior e cêrca de 10 segmentos do abdômen.

Descrição - Os dois exemplares são minúsculos, medindo apenas cêrca de $15 \mathrm{~mm}$, para 28 setígeros; porém, exceto quanto às proporçôes, correspondem estreitamente às descrições de Fauvel.

Três pares de brânquias ramificadas e 17 setígeros torácicos. Cerdas, limbadas, a partir do $3 .^{\circ}$ segmento branquial. Uncini pectiniformes, com 5-6 dentes, formando fileiras duplas, opostas dorso a dorso. Setígeros abdominais com toros uncinígeros em forma de pínula quadrada.

Discussão - As proporções dos exemplares aqui descritos, são semelhantes às de Loimia minuta Treadwell. $\mathrm{O}$ espécimem em que se baseou a descrição dessa espécie, era também incompleto e media apenas $22 \mathrm{~mm}$ de comprimento, dos quais $11 \mathrm{~mm}$ para o tó$\operatorname{rax}$ (Treadwell, 1929a, p. 392-393). A forma e número de dentes dos uncini (fig. 30) também coincidem.

Loimia turgida Andrews e Loimia minuta Treadwell foram colocadas na sinonímia de $L$. medusa, por Hartman (respectivamente em 1945 e 1956).

Distribuição - Loimia medusa foi descrita do Mar Vermelho e é considerada espécie cosmopolita. DAY (1967a) registra sua ocorrência no f́ndico tropical, Pacífico, Sul da África e Madagascar. No Atlântico americano, ocorre de North Carolina até o México e Nordeste do Brasil (Alagoas).

Gênero Pista Malmgren 1866

Pista cf. cristata (O. F. Müller) 1776

Pista cristata (Müller). Fauvel, 1927, p. 266, fig. 93, a-g.

1 exemplar incompleto (AK 103, L-D).

Distribuição - Espécie cosmopolita, com ampla distribuição nos mares quentes e temperados. No Atlântico ocorre desde a Suécia e North Carolina até Angola e o sul da Argentina.

\section{Pista sp.}

2 exemplares incompletos; minúsculos e parcialmente macerados (AK 88, BAC e AK 184, D). 
Gênero Streblosoma Sars 1872

Streblosoma cf. bairdi (Malmgren) 1886

(Fig. 89-91)

Grymaea bairdi Malmgren, 1866, p. 388-389, est. 19, fig. 69.

Streblosoma bairdi (Malmgren). Fauvel, 1927, p. 275, fig. 96, f-n.

? Streblosoma verrilli Treadwell, 1911.

1 exemplar, presumivelmente completo (AK 59, ACL), medindo cêrca de $42 \mathrm{~mm}$ de comprimento.

Descrição - 0 exemplar, pequeno para a espécie (que alcança, segundo Fauvel, até $80 \mathrm{~mm}$ ) é maduro, com a cavidade do corpo repleta de grandes ovos.

Corpo longo, anteriormente dilatado. Tentáculos comprimidos, longos, canaliculados. Brânquias cilíndricas, curtas e relativamente grossas, pouco numerosas; agrupadas em séries transversais de 3-8 filamentos, de cada lado dos segmentos $2 .^{\circ}$ a $4 .^{\circ}$.

30 setígeros torácicos; cerdas dorsais a partir do primeiro segmento branquial. Uncini a partir do último segmento branquial $\left(3 .^{\circ}\right.$ setígero); o toro do lado esquerdo (em vista dorsal) reduzido a alguns uncini apenas.

Cerdas de um único tipo, limbadas, lanceoladas; de comprimento desigual. Setígeros anteriores do tórax com 12-15 cerdas dispostas em duas séries paralelas e em léque (Fig. 89). Uncini com o dente principal encimado por dois dentes accessórios grandes, paralelos, e em número variável de dentículos meno. res (Fig. 90 e 91). Toros uncinígeros dos últimos segmentos torácicos e dos segmentos abdominais, em forma de pínulas longas e estreitas.

Região abdominal constituída por cêrca de 30 setígeros.

Côr, no álcool - Castanho-avermelhado; almofadas ventrais branco-amarelado.

Discussão - 0 exemplar coincide razoàvelmente bem com a descrição de $S$. bairdi, feita por FAUVEL (1927). A forma e disposição das brânquias é a característica para o gênero e a forma dos uncini assemelha-se à figurada por Malmgren (fig. 69 D) e por Fauvel (fig. 96, m-n).

A figura 69 de Malmgren mostra o primeiro toro uncinígero no $6 .^{\circ}$ segmento, porém, FAUVEL (p. 274 , fig. 96 , f) o coloca sôbre o $5 .^{\circ}$ ( $4 .^{\circ}$ setígero e $2 .^{\circ}$ branquial). Em nosso exemplar, o primeiro toro uncinígero aparece sôbre o $3 .^{\circ} \mathrm{e}$ último segmento branquial. Essa condição, que pode ser anômala, foi descrita por Treadwell, em Streblosoma verrilli, da Flórida (1911, p. 11-12): "Setae in each parapodium, beginning on lst branchial somite, borne on a proeminent papilla, arranged in a simple row. ...Uncini begin on 3rd branchial somite, in a single row of about $30 "$ (p. 12).

A ocorrência simultânea da primeira brânquia e do primeiro feixe de cerdas é característica para o gênero Streblosoma, entretanto Hartman (1956, p.
257-258) colocou $S$. verrilli na sinonimia de Thelepus setosus, mencionando (p. 297) que "setae are first present from the second branchial segment and uncini from the third setigerous one".

Parece-nos admissível que o exemplar examinado por Hartman não tenha sido o mesmo descrito por Treadwell.

Se nos ativermos à descrição original é óbvio que S. verrilli é um legítimo Streblosoma, singularmente semelhante ao desta coleção.

A exiguidade do material não nos permite verificar a constância dos caracteres e uma eventual identidade com a espécie de Treadwell.

S. bairdi var. antarctica Monro (1936, p. 182. -183, fig. 32) da Georgia do Sul é muito próximo de bairdi e de verrilli, como reconhece o próprio autor.

Distribuição - S. bairdi é conhecido do Atlântico Norte e dos mares árticos (Fauvel); a ocorrência atual, se confirmada, estende sua distribuição ao Atlântico americano.

\section{Gênero Thelepus Leuckart 1849 \\ Thelepus sp.}

1 exemplar incompleto (AK 18, BAC) constituído pela região anterior e 5 segmentos abdominais; medindo cêrca de $48 \mathrm{~mm}$ de comprimento.

Descrição - Corpo longo e robusto, afinando gradualmente na região posterior. Primeiro segmento com largo lóbulo dorsal lamelar e uma cintura de manchas oculares minúsculas, na base. Tentáculos de largura uniforme, longos e canaliculados. Três pares de feixes branquiais; o último sôbre o $3 .^{\circ}$ setígero. Cada feixe branquial é formado por cêrca de 10 filamentos longos, agrupados em duas fileiras transversais superpostas e parcialmente fundidos na linha de inserção. Quando contraídas, as brânquias se enrolam em espiral apertada.

40 setígeros torácicos, dos quais 19 com almo. fadas glandulares ventrais. Uncini a partir do segmento post-branquial ( $3 .^{\circ}$ setígero); dispostos em linha simples em todos os segmentos. 0 dente prin. cipal dos uncini torácicos é encimado por dois dentes accessórios, grandes e divergentes. Cerdas de único tipo, limbadas, com lâmina larga e estriada.

Côr, no álcool - Castanho-avermelhado; brânquias e tentáculos amarelo claro.

Discussão - $O$ exemplar é incompleto e parciaimente macerado. Ainda que muitas de suas características essenciais estejam perfeitamente preservadas, não nos parecem suficientes para uma identificação segura.

Trata-se, indubitàvelmente, de uma espécie muito próxima de Thelepus setosus (Quatrefages); a forma espiralada das brânquias sugerindo uma possível identidade com $T$. crispus Johnson (1901, p. 428, est. 17, fig. $175-178 \mathrm{~b}$ ).

Os uncini são semelhantes aos de Streblosoma magna TrEadWell (1937, est. 2, fig. 26-28), espécie 
que Hartman (1956, p. 297) colocou na sinonímia de $T$. crispus.

Berkeley \& Berkeley (1942) caracterizaram as duas espécies, $T$. setosus e $T$. crispus, como espécies distintas, ainda que próximas. Ambas são comuns na costa pacífica do Canadá e Estados Unidos, sendo que, no Atlântico, T. setosus ocorre também no Gôlfo do México (Hartman, 1956), costa da África, Malvinas e Argentina (Day, 1967a).

\section{Família TRICHOBRANCHIDAE Hessle 1917 Gênero Terebellides Sars 1835 \\ Terebellides anguicomus Fritz Müller 1858}

Terebellides anguicomus Fritz Müller, 1858, p. 218, est. 7, fig. 22. Hessle, 1917, p. 141, fig. 33 .

1 exemplar completo (AK 122, ACL).

Diagnose - Corpo relativamente curto, claviforme, com 17 setígeros torácicos. Bordo anterior do lóbulo cefálico arredondado e ondulado, com numerosos tentáculos extensíveis. Um único tronco branquial, robusto, inserido sôbre os segmentos III e IV, reunindo 4 brânquias lamelosas, coalescentes na base.

Os 4 primeiros setígeros são providos ùnicamente de cerdas capilares limbadas; o $5 .^{\circ}$ setígero é caracterizado pela presença de grossas cerdas aciculares geniculadas, ponteagudas, formando o feixe ventral. Os demais setígeros torácicos têm cerdas dorsais capilares e uncini de haste longa, com o dente distal cercado de numerosos dentículos. Toros abdominais em forma de pínulas salientes, com uncini aviculares.

Discussão - Terebellides anguicomus Fritz Müller distingue-se das espécies congêneres por possuir apenas 17 setígeros torácicos e cerdas aciculares geniculadas no $5 .^{\circ}$ setígero. $\mathrm{Na}$ realidade, a única diferença entre esta espécie e $T$. stroemi Sars, que possui 18 torácicos, é a falta de um setígero anterior. Tal diferença foi considerada significativa por HEsSLE (1917) que aceita como válida a espécie de Fritz Müller.

Tendo examinado, além do exemplar desta coleção, um amplo material oriundo de vários pontos da costa sul do Brasil e verificado a constância dos caracteres específicos, temos razões para crer que as duas espécies são realmente distintas.

Quanto a Terebellides klemani descrita por Kinberg, da costa brasileira, e colocada por Hessle na sinonímia de $T$. anguicomus, não temos elementos para apreciar sua verdadeira posição. HARTMAN (1948, p. 14), na revisão dos tipos de Kinberg, não discute essa espécie, louvando-se apenas na opinião de Hessle, que é particularmente lacônica.

Distribuição - 0 tipo de Terebellides anguico. mus proveio da costa de Sta. Catarina e observações nossas, ainda não publicadas, indicam que a espécie é comum no litoral dos Estados de São Paulo e Rio de Janeiro. O exemplar desta coleção provém da costa de Sergipe.
Família SABELLIDAE Malmgren 1867

Gênero Hypsicomus Grube 1870

Hypsicomus circumspiciens Ehlers 1887

(Fig. 92-97)

Hypsicomus circumspiciens Ehlers, 1887, p. 271-277, est. 55, fig. 5-13; est. 56, fig. 1-3. Johansson, 1927, p. 139-141.

2 exemplares, em seus tubos; sendo um com. pleto, com cêrca de 150 setígeros, medindo $120 \mathrm{~mm}$ (AK 102-b, A) e um fragmento anterior com cêrca de 100 setígeros, medindo $65 \mathrm{~mm}$ (AK 131, ACL).

Descrição - Corpo longo e muito delgado, de diâmetro uniforme. Penacho branquial com cêrca de 30 radíolos; dois "tentáculos" subulados, longos; duas manchas oculares conspícuas, na base das brânquias. Cada filamento branquial possui, em seu têrço me. diano, duas linhas de olhos, cuja côr intensa subsiste mesmo após longa permanência no álcool.

Região torácica constituída por 12 a 15 setígeros. O primeiro ("colar"), duas vêzes mais longo que os seguintes e com um profundo sulco ventral, é provido ùnicamente de cerdas limbadas, dispostas em linha longitudinal aproximadamente reta (Fig. 93). Os demais segmentos torácicos têm cerdas dorsais de dois tipos: limbadas, mais longas e espatuladas, curtas e robustas, com extremidade arredondada (Fig. 94 e 95). No ramo ventral, uncıni aviculares e cerdas "en pioche" (Fig. 96), em linha dupla.

Região abdominal com tóros dorsais, contendo ùnicamente uncini semelhantes aos torácicos; ramo ventral com cerdas de 3 tipos: capilares, em número de uma ou duas; limbadas, também em pequeno número e espatuladas, estas em sua maioria com um prolongamento longo, acuminado (Fig. 97).

Tubo córneo, vítreo e liso, de côr escura e com parede espêssa.

Discussão - Hypsicomus circumspiciens Ehlers é a única espécie do gênero a possuir 12-15 setígeros torácicos, em oposição aos 8 , comuns às demais (6-8 em $H$. elegans). A disposição das cerdas do colar, em fila pràticamente reta é, também, peculiar. A única outra espécie em que ocorre disposição semelhante é $H$. capensis DAY (1961, p. 534, fig. 13, g), da qual esta se distingue pelo maior número de setígeros torácicos.

Johansson (1927, p. 140) menciona para $H$. circumspiciens apenas 8 setígeros torácicos. Acreditamos, porém, que se trata de um engano, pois o autor não comenta a discrepância com a descrição original de Ehlers (p. 275, est. 55, fig. 6).

Distribuição - Antilhas e Nordeste do Brasil (Alagoas e Sergipe).

Hypsicomus elegans (Webster) 1884

(Fig. 98-100) 
Protulides elegans Webster, 1884, p. 325-326, est. 11, fig. 63-74. Andrews, 1891, p. 299.

Hypsicomus elegans (Webster). Hartman, 1951, p. 115.

Hypsicomus torquatus (Grube). Hartman, 1945, p. 47-48.

Sabella alba Treadwell, 1919, p. 267 , est. 3, fig. 30-33. Hartman, 1956, p. 258.

2 exemplares completos, em seus tubos (AK 21, $\mathrm{H}$ e $\mathrm{AK}$ 184, ACL) respectivamente com cêrca de 80 e 70 setígeros, o maior medindo $42 \mathrm{~mm}$ de comprimento.

Descrição - Corpo longo, relativamente robusto. Penacho branquial formado por 15 pares de radíolos delicados, com manchas oculares distribuídas simètricamente. Colar $\left(1 .^{\circ}\right.$ setígero $)$ baixo, com uma incisão ventral atingindo $2 / 3$ de sua altura; provido de cerdas limbadas, dispostas em fila sinuosa, oblíqua.

Tórax constituído por 8 setígeros; feixes dorsais com cerdas limbadas e cerdas espatuladas com pequena ponta (Fig. 98); toros ventrais com uncini aviculares e cerdas "en pioche", em fileiras justapostas.

Segmentos abdominais com uncini aviculares semelhantes aos do tórax (Fig. 99 e 100), cerdas limbadas e cerdas espatuladas com um longo prolongamento afilado.

A face ventral do último segmento torácico e dos segmeritos abdominais é recoberta por espêssas almofadas glandulares, de côr escura. Pigídio com duas manchas pigmentares conspícuas.

Tubo córneo translúcido, resistente e muito mais longo que o animal.

Discussão - Hypsicomus elegans (Webster) é uma espécie do Atlântico americano, muito próxima de $H$. torquatus (Grube), descrita da costa ocidental da África.

JoHANSSON (1927, p. 141) não discute esta espécie, se limitando a colocá-la na sinonímia de $H$. torquatus; baseando-se na opinião de Augener. Entretanto, a descrição de GRUBE (1877, p. 549-550) não é suficiente para uma caracterização decisiva e a ausência de figuras e de menção explícita às cerdas do colar, impedem uma comparação mais minuciosa.

Augener (1922, p. 49) é lacônico e incorreto, ao escrever a propósito de $H$. torquatus: "Synonym mit dieser west indischen Art ist Protulides elegans Webst. (1884)". H. torquatus não é "espécie das Antilhas", tendo sido descrita por Grube de lugar indeterminado da costa da África e, de acôrdo com o próprio Augener, tem ampla distribuição nessa área. No mesmo trabalho, o autor (p. 575) considerou Protulides elegans de Webster como idêntico a $H$. cir. cumspiciens Ehlers, essa sim, espécie das Antilhas.

Quanto a uma suposta identidade entre elegans e circumspiciens, como admitido por HaRTMan (1951, p. 115), parece-nos de todo improvável. As características do colar e o número de setígeros torácicos distinguem, satisfatòriamente as duas espécies.

Assim sendo, consideramos válida a espécie de Webster e a ela identificamos alguns dos exemplares de Hypsicomus desta coleção.

Distribuição - Antilhas; costa leste dos Estados Unidos até North Carolina (Hartman, 1945); Nordeste do Brasil (Alagoas e Sergipe).

\section{Gênero Laonome Malmgren 1866 Laonome sp.}

1 exemplar, sem o penacho branquial (AK 102, L-D), com 95 setígeros, medindo $52 \mathrm{~mm}$ de comprimento.

Descrição - Colar baixo, com dois lóbulos ventrais bem desenvolvidos. Almofadas glandulares largas e inteiras nos segmentos torácicos; divididas na linha mediana a partir do $2 .^{\circ}$ setígero abdominal. Primeiro setígero oculto pelos lóbulos do colar e provido ùnicamente de cerdas dorsais, limbadas.

8 setígeros torácicos, providos, à exceção do primeiro, de cerdas limbadas longas e cerdas sub-espatuladas, mais curtas. Manchas de pigmento distribuídas regularmente na base dos feixes de cerdas e na extremidade dos toros uncinígeros, ao longo de todo o corpo. síveis.

Pigídio ligeiramente espatulado, sem olhos vi-

A ausência do penacho branquial impede uma comparação mais pormenorizada.

Gênero Megalomma Johansson 1927

Megalomma bioculatum (Ehlers) 1887

(Fig. 101)

Branchiomma bioculatum Ehlers, 1887, p. 260, est. 53, fig. 1-9. Augener, 1918, p. 570-572.

Megalomma bioculatum (Ehlers). Hartman, 1965, p. 234. Day, 1967a, p. 760.

1 exemplar completo (AK 22, BAC), medindo $19 \mathrm{~mm}$ de comprimento.

Descrição - 0 exemplar é pequeno mas perfeito, com 8 setígeros torácicos e 56 abdominais. Colar bem desenvolvido, com dois lóbulos ventrais, triangulares. Brânquias em número de $11 \mathrm{em}$ cada feixe; tentáculos com a base larga, folhosa. 0 radíolo interno (dorsal) de cada feixe, com um grande ôlho composto, sub-terminal.

Cerdas torácicas, limbadas, com lâmina larga. Toros uncinígeros com uma fileira de cerdas "en pioche" e uncini aviculares com haste longa.

Pigídio ligeiramente espatulado, com duas manchas oculares na extremidade. 
Discussão - Megalomma bioculatum (Ehlers) é descrito por DAY (1967a) como uma espécie pequena, atingindo apenas $20 \mathrm{~mm}$ de comprimento e os exemplares de Augener (1918) da costa ocidental da África, não mediam mais que $25 \mathrm{~mm}$. Também o exemplar desta coleção, como os tubos coletados por Hartman (1965) ao largo da Nova Inglaterra e Flórida, não ultrapassa essa medida. Porém, o tipo, de Ehlers, é consideràvelmente maior, com 73 $\mathrm{mm}$, dos quais 47 para o corpo.

Distribuição - North Carolina, Flórida e Africa ocidental (Day). Sua ocorrência na costa brasileira do Nordeste (Alagoas) é assinalada pela primeira vez.

\section{Família SERPULIDAE Savigny 1818 \\ Gênero Crucigera Benedict 1886}

Crucigera Benedict. Bush, 1904, p. 232. Chamberlin, 1919, p. 476.

O gênero Crucigera Benedict se caracteriza pelo pedúnculo opercular provido de 4 expansões digitiformes, dispostas em cruz. $\mathrm{O}$ opérculo é infundibuliforme, com a parte superior radialmente estriada e o bordo denteado (cf. Chamberlin).

Cerdas do colar, de dois tipos: capilares e em baioneta com dois esporóes (tipo Serpula).

\section{Crucigera websteri Benedict 1886}

(Fig. 102-105)

Crucigera websteri Benedict, 1886, p. 550 , est. 21, fig. 24-25; est. 22, fig. 26-30. Berkeley \& Berkeley, 1941, p. 57. Hartman, 1961, p. 44.

Serpula (Crucigera) websteri Benedict. Monro, 1933 a, p. 1079-1080.

Serpula (Crucigera) websteri var. tricornis, Gravier, 1908, p. 117-118, fig. 473-475; est. 8, fig. 289.

1 exemplar completo, em seu tubo (AK 184, D), medindo $19 \mathrm{~mm}$ de comprimento.

Descrição - Espécie pequena e robusta. Opérculo em taça, com a superfície côncava estriada radialmente e o bordo guarnecido por cêrca de 60 pequenos dentes cônicos. Pedúnculo opercular com inserção excêntrica, dotado, logo abaixo do opérculo, de quatro expansões subuladas, dispostas simètricamente em posição normal à haste (Fig. 102). Um falso opérculo claviforme, com pedúnculo curto. Radíolos branquiais com longa extremidade lisa.

Tórax constituído por 7 setígeros; o primeiro ("colar") com um feixe de 4-5 cerdas capilares e 3 cerdas em baioneta, robustas (Fig. 103). Demais setígeros torácicos com cerdas limbadas longas e uncini aviculares, com 5 dentes, dispostos em série simples. Setígeros abdominais anteriores com toros dorsais muito longos, com uncini semelhante aos torácicos e um feixe de cêrca de 12 cerdas em espátula, com o bordo reto e denteado (Fig. 104). Nos setígeros da região posterior, as cerdas em espátula são substituídas por 2-3 cerdas capilares, muito longas, rígidas e delgadas.

Côr, no álcool - Castanho-avermelhado, intenso; penacho branquial mais claro.

Tubo branco, cilíndrico e sinuoso, com 3 cris. tas longitudinais corrugadas (Fig. 105).

Discussão - Crucigera Benedict, foi considerado, por SAINT-Joseph (1886) como um sub-gênero de Serpula; opinião aceita por Gravier (1908) e MonRo (1933a). Autores atuais, porém, o consideram gê. nero válido.

A presença de grandes apêndices digitados, no pedúnculo opercular distingue decisivamente, êste gênero, de Serpula. Expansões semelhantes são características também do gênero Omphalopomopsis que, entretanto, as têm menores e de forma triangular, em número de apenas 3 . As cerdas do colar, das espécies dêste último gênero, são aciculares, clavadas ou lanceoladas, totalmente diferentes das de Crucigera.

Gravier (1908) descreveu uma variedade tricor. nis, baseado n'um exemplar do Mar Vermelho, que possuia apenas ) apêndices no pedúnculo opercular. O caráter, constatado n'um único espécimem, constitui, verossimilmente, uma simples anomalia.

Crucigera zygophora (Johnson) 1901, é uma espécie diferente desta, como evidenciaram Berkeley \& Berkeley (1941). Não só o número de raios do opérculo é muito menor, como as projeções da haste são inteiramente diferentes (vide JoHNSON, 1901, est. 19, fig. 205).

Distribuição - Gôlfo do México e Califórnia; Panamá; Mar Vermelho. Nordeste do Brasil (Sergipe).

Gênero Hydroides Gunnerus 1768

Hydroides californicus Treadwell 1929

Hydroides californicus Treadwell, 1929a, p. 12, fig. 32 e 33. Rioja, 1941, p. 161-164, est. 1, fig. $1 \cdot 10$.

1 único exemplar, completo (AK 181, A-L), medindo $7,5 \mathrm{~mm}$ de comprimento.

Descrição - Espécie pequena e delicada; êste exemplar, como os de RioJA (1941) mede menos que $12 \mathrm{~mm}$ de comprimento.

Opérculo em cálice irregular, profundamente sulcado e com o bordo dividido em cêrca de 24 lóbulos (Fig. 106). Espinhos do verticilo superior, em número de seis; quitinosos, longos e com as pontas recurvadas para dentro. Cada espinho tem, aproximadamente na metade de sua altura, duas expansões laterais uncinadas, opostas. Pedúnculo opercular cilíndrico, longo e liso. Cerdas do colar, capilares e ent baioneta, estas com dois esporões longos e de extre- 
midade arredondada (Fig. 107). Demais setígeros torácicos com cerdas limbadas e uncini com 4-6 dentes (Fig. 108 e 109). Segmentos abdominais com uncini semelhantes aos do tórax e cerdas em espátula, com haste longa e bordo serrilhado.

Tubo cilíndrico, com três cristas longitudinais. baixas e irregulares.

Discussão - Hydroides californicus foi sumàriamente descrito por Treadwell. A falta de figuras do opérculo, na descrição original, a torna um tanto vaga.

RioJA (1941), considerou como pertencentes a esta espécie, vários exemplares de Hydroides prove. nientes de Acapulco e Mazatlán (México). Suas ilustrações do opérculo (est. 1, fig. 1 e 2) são excelentes e a descrição bastante pormenorizada.

Uma identidade entre esta espécie e H. crucigera Mörch, como admitiu o próprio RioJA, em 1944 (p. 409), nos parece improvável. O tipo de Hydroi. des crucigera provém de Puntarenas, e, portanto, de águas antárticas e a descrição de Mörch, para o opérculo (transcrita por Monro, 1933a, p. 1083) não é, em absoluto, conclusiva.

Há, ainda, uma marcada discrepância entre os primeiros exemplares estudados por Rioja (do México) e os subseqüentes, da Califórnia. Êstes últimos, como declara o autor, coincidiriam com a descrição e figuras de Monro (1933a, p. 1083, fig. 261. Porém, são muito maiores ("es decir, que son casi todos ellos de un tamaño doble a los conocidos hasta ahora"); o opérculo tem maior número de dentes marginais (em lugar de 24-30, tem 38-50); finalmente, a forma dos espinhos do verticilo superior pode ser considerada significativamente diferente.

Parece-no muito mais provàvel uma identidade com Hydroides bispinosa Bush, das Bermudas; como aliás, mencionou RioJA em 1941 (p. 164).

Com a única exceção do menor número de espinhos no verticilo superior, a descrição de $H$. californicus se aplica corretamente ao exemplar desta coleção.

Distribuição - Califórnia, México e Panamá. Nordeste do Brasil (Sergipe).

Gênero Serpula Linneu 1758

Serpula vermicularis Linneu 1767

Serpula vermicularis Linneu. Fauvel, 1927, p. 351-352 , fig. 120 , a-q.

1 exemplar, parcialmente macerado (AK 184, D), medindo cêrca de $25 \mathrm{~mm}$ de comprimento. vel.

$\mathrm{O}$ exemplar corresponde bem à descrição de Fau-

A espécie é próxima de Crucigera websteri Benedict, que ocorreu na mesma amostra, distinguindo-se desta, principalmente, pelo pedúnculo opercular inteiramente liso.
Distribuição - S. vermicularis é espécie cosmo. polita, com ampla distribuição nos mares quentes e temperados. No Atlântico ocorre desde o Mar do Norte até o sul da África e o Estreito de Magalhães.

Gênero Vermiliopsis St. Joseph 1889

Vermiiopsis acanthophora Augener 1914

(Fig. 110-111)

Vermiliopsis acanthophora Augener, 1914, p. 155-156, est. 1, fig. 21-24. Monro, 1933a, p. 1085. Fauvel, 1947, p. 96-97, fig. 89, a-c. 1953, p. 467, fig. 243 , c-e. Dew, 1959 , p. $31-33$, fig. 9. Day, 1967a, p. 814, fig. 38.6, j-k.

1 exemplar incompleto (AK 03, BAC), constituído pela região anterior e 6 segmentos abdominais, medindo $13 \mathrm{~mm}$ de comprimento, inclusive o penacho branquial.

Descrição - Forma pequena, delicada. Expansões aliformes do colar recobrindo inteiramente o tórax. Radíolos branquiais com extremidade não dilatada. Opérculo córneo, cilíndrico e inteiro, orlado por 6 cristas paralelas e encimado por uma placa com um único espinho cônico, unciforme, no centro (Fig. 110). Pedúnculo opercular claviforme, desprovido de expansões laterais.

Tórax com 7 setígeros; o primeiro ("colar") com cerdas capilares limbadas; os demais com cerdas limbadas, robustas e algumas cerdas geniculadas, com a lâmina conspìcuamente serrilhada ("cerdas de Apomatus"). Uncini pectiniformes, com 9-10 dentes longos, aguçados e um apêndice distal em forma de goiva (Fig. 111). Os segmentos abdominais são providos de cerdas essencialmente semelhantes às do tórax e de uncini menores, com cêrca de 12 dentes. Os fragmentos remanescentes do tubo não permitem apreciar suas características.

Discussão - Ainda que incompleto, o exemplar de Vermiliopsis acanthophora desta coleção pôde ser identificado com razoável segurança. Suas caracterís. ticas coincidem com as referidas na diagnose original.

Augener baseou sua descrição n'um único espécimem, da Austrália Ocidental; porém, posteriormente a espécie foi encontrada com relativa freqüência nessa área e em diferentes pontos do Pacífico e do Índico. As eventuais deficiências da diagnose baseada n'um só exemplar são supridas pela constância dos caracteres específicos, verificada em material da mesma e de diversa procedência.

A redescrição da espécie, feita por DAY (1967 a, p. 814) é simples e precisa, não deixando qualquer dúvida quanto à sua caracterização.

Quanto à arquitetura do tubo, originalmente considerada característica para a espécie, não nos pare. ce ter valor diagnóstico. A forma do tubo no gênero Vermiliopsis é susceptível de considerável variação, como reconheceram FAUveL \& RULLIER (1959a, p. 984-985 na discussão de $V$. infundibulum). No caso 
particular de $V$. acanthophora, o tubo figurado por DEW (p. 32, fig. 9.A) difere bastante da descrição e do desenho de Augener (est. 1, fig. 24). Assim sendo, acreditamos que a falta do tubo não constitui obstáculo à correta identificação do nosso exemplar de Vermiliopsis.

A forma do opérculo parece ser, igualmente, passível de certa variação. Deploràvelmente, apesar da espécie haver sido assinalada em cêrca de uma dezena de pontos diferentes, as únicas figuras do opérculo são as de Augener (hàbitualmente) reproduzidas e as de Dew. Ainda que estruturalmente semelhantes, há sensíveis diferenças entre os opérculos figurados pelos dois autores. O opérculo do nosso exemplar é muito semelhante ao desenhado por DEw.

DAY menciona, pela primeira vez, a forma peculiar em goiva do apêndice distal dos uncini de $V$. acanthophora: "Thoracic uncini with about nine to ten teeth and a terminal gouge". Os uncini do exemplar desta coleção correspondem exatamente a essa descrição; têm 9.10 dentes longos e um processo terminal largo e canaliculado. A forma em goiva é perfeitamente conspícua, ainda que, um exame super. ficial revele apenas a extremidade aparentemente "bifurcada". Entretanto, não podemos atribuir importância decisiva a êsse caráter, em virtude da imprecisão na descrição dos uncini das espécies congêneres. A própria diagnose de Augener se refere a um apenas "abgestumpften Zahn".

Singularmente, a única outra espécie de Vermiliopsis com uncini providos de apêndice terminal "bifurcado" é $V$. occidentalis (McIntosh), (1885, est. 29 A, fig. 32). Essa espécie, descrita das Bermu. das (como Spirobranchus), teria também um opérculo aproximadamente cilíndrico, com placa apical provida de um espinho simples (HarTMAN, 1942a, fig. 156).

Uma comparação entre $V$. acanthophora e $V$. occidentalis nos parece difícil porque, desta última encontramos apenas a descrição original e referências sumárias, insuficientes para uma conclusão ponderada.

Dispondo de um único exemplar e de limitada experiência na família, não podemos avaliar satisfatòriamente as relações entre acanthophora e as espécies de Vermitiopsis assinaladas no Atlântico tropical.

Distribuição - Austrália (Shark Bay e New South Wales - Dew, 1959) ; Oceano Índico (Ceylão e cos. tas da Arábia - Monro, 1937); Oceano Pacífico (Ilhas Gambier — FAUVEL, 1947; Galapagos — MoNRo, 1933a); Nordeste do Brasil (Alagoas).

\section{CONSIDERAÇÕES FAUNİSTICAS}

O exame da coleção atual revela uma considerável afinidade entre a fauna de poliquetas do Nordeste do Brasil e a da região das Antilhas e Gôlfo do México.
A coleção é muito pequena para fundamentar um estudo comparativo mais aprofundado; porém, em alguns casos como ocorre com os Eunicidae, tal afinidade é bem aparente. Das 14 espécies da família encontradas nas costas de Alagoas e Sergipe, apenas 3 não foram referidas para a região caraíbica: $E$. biannulata, E. (Nicidion) imogena e M. stylobranchiata. Não considerando também $E$. vittata e $L$. ninetta, que são cosmopolitas, subsistem 9 espécies de Eunicidae que podem ser consideradas endêmicas.

Uma comparação mais minuciosa nos parece particularmente difícil. Como acentuamos na discussão de Eunice floridana, a identificação de uma espécie é, muitas vêzes, condicionada por fatôres subjetivos. $\mathrm{Na}$ impossibilidade de examinar cada um dos tipos, geralmente são aceitas como fidedignas as descrições originais, nem sempre exatas ou completas. As re-descrições baseadas em exemplares de procedência diversa e, òbviamente, orientadas pela opinião do autor podem estender a distribuição de uma espécie a uma área muito ampla. Tão ampla na verdade que, através de sucessivas "ocorrências", a espécie passa a ser considerada como cosmopolita.

Mencionamos, relativamente ao nosso material, duas observações que ilustram essa circunstância.

Anaitides madeirensis (Langerhans) foi descrito da Ilha da Madeira e sua presença no Nordeste do Brasil nos parece perfeitamente compatível com o ambiente que aí predomina. Entretanto, EHLERs (1897, p. 25) refere sua ocorrência na Georgia do Sul (Antártica), considerando-a como espécie cosmopolita. Hartman (1964, p. 51) também a menciona, com várias referências na Antártica, iniciando a diagnose com a observação singular e pertinente: "These references may refer to more than one species, none of which is the same as $A$. madeirensis, from Mediterranean areas"! Portanto, é muito provável que $A$. madeirensis não ocorra no Artico e que sua distribuição real seja muito mais coerente.

A segunda observação diz respeito a Pareulepis fimbriata (Treadwell), até recentemente considerada sinônimo de $P$. geay (Fauvel); a primeira, das Antilhas e a segunda, do Índico. O próprio FAuvel e, posteriormente, Rullier admitiram a identidade de ambas (vide a "discussão" da espécie). Porém, um estudo minucioso, de Pettibone (1969), revelou que as duas espécies são perfeitamente distintas. De acôrdo com Pettibone (p. 26 e 29) a distribuição de fimbriata seria limitada às Antilhas e lado atlântico do Panamá; enquanto a área de geay abrange a costa oriental da África, Nova Caledônia e Mar Vermelho.

Consideramos perfeitamente admissível que algumas espécies do Atlântico tropical existam também no Pacífico e no f́ndico e vice-versa.

Assim, por exemplo, a presença de Vermiliopsis acanthophora entre as espécies desta coleção encontra precedente na ocorrência de Eunice floridana e Glycera americana, assinaladas no Índico, respectivamente por FAUvel (1953) e por Augener-(Die Fauna Südwest-Australiens. Polychaeta Errantia, 1913). 
Chloeia viridis Schmarda

1. Animal total; vista dorsal. 2. Região anterior; vista dorsal

Notopygos crinita Grube

3. Regiăo anterior; vista dorsal. 4. Segmento mediano, em corte (órgãos internos não representados). 

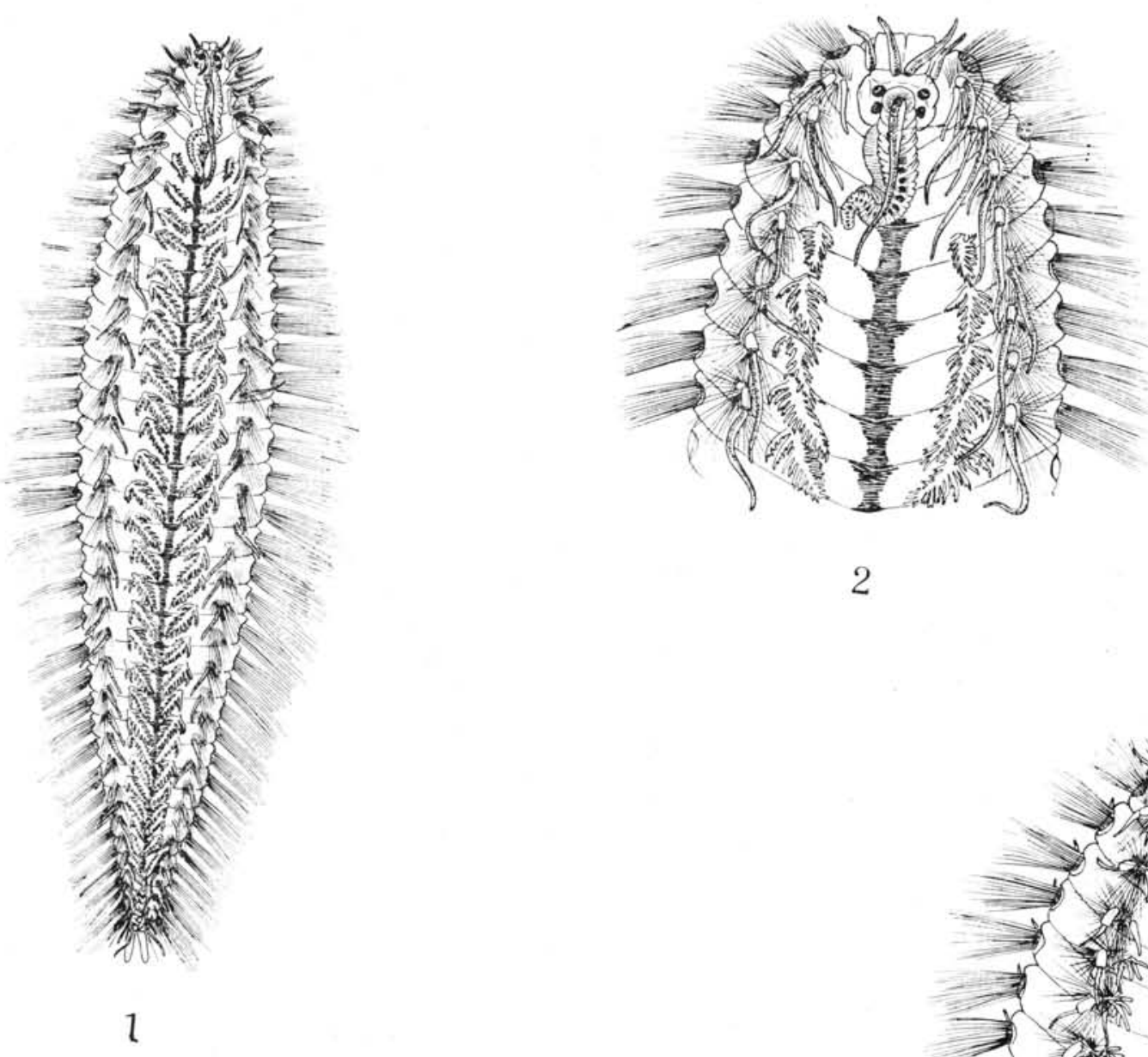

2
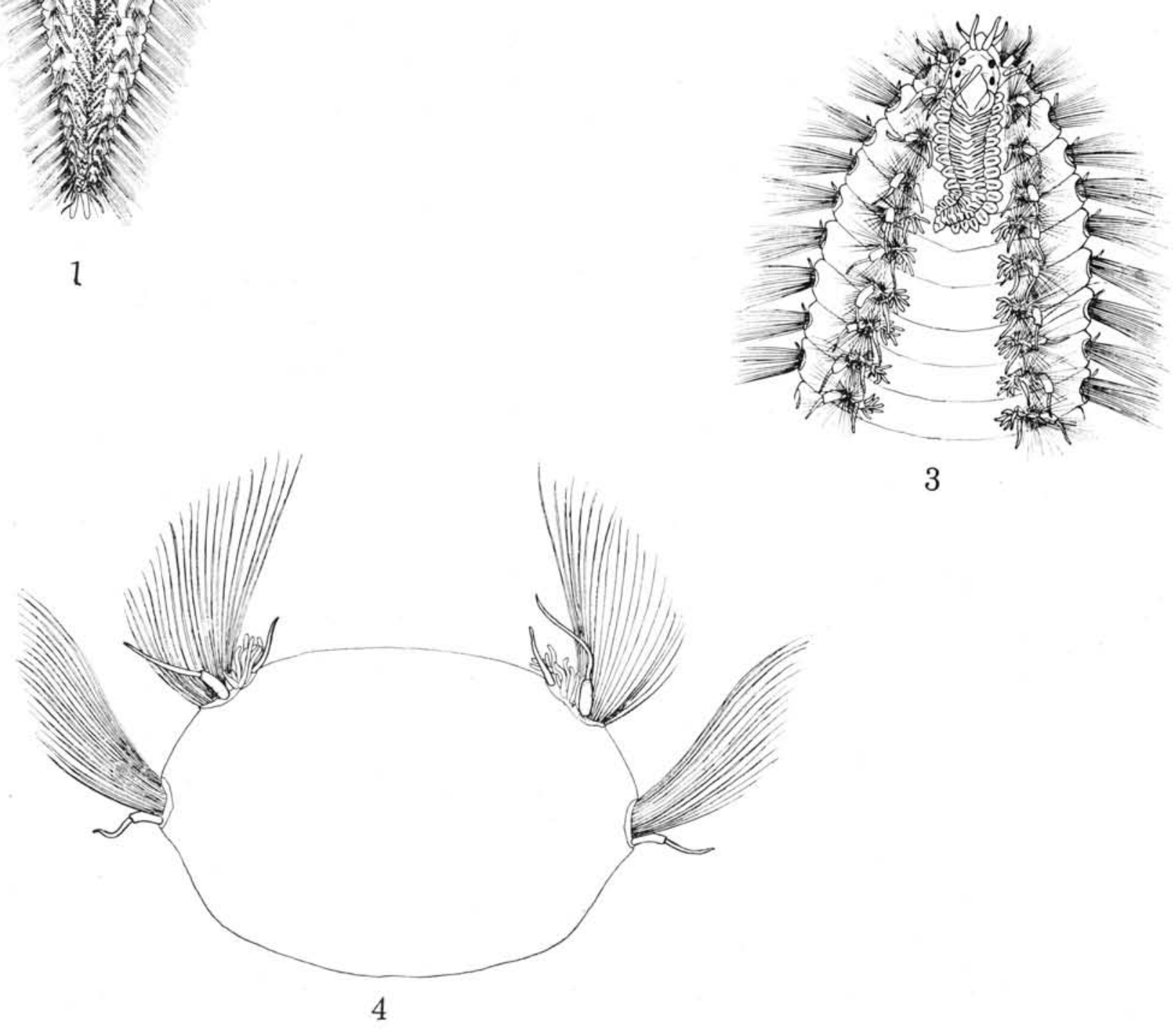

3

Bolm Inst. oceanogr. S Paulo, 19:57-130, 1970 
Anaitides madeirensis (Langerhans)

5. Regiảo anterior, com tromba evaginada; vista dorsal. 6. Extremidade da tromba; vista frontal. 7. Pé da região anterior. 8. Cerda composta, vista de frente,

Hesione picta Fritz Müller

9. Região anterior; vista dorsal.

Synelmis albini (Langerhans)

10. Regiāo anterior, com tromba evaginada; vista dorsal. 11. Pé da região anterior.

12. Pé da região mediana. 13. Pé da região posterior. 14. Cerda furcada. 

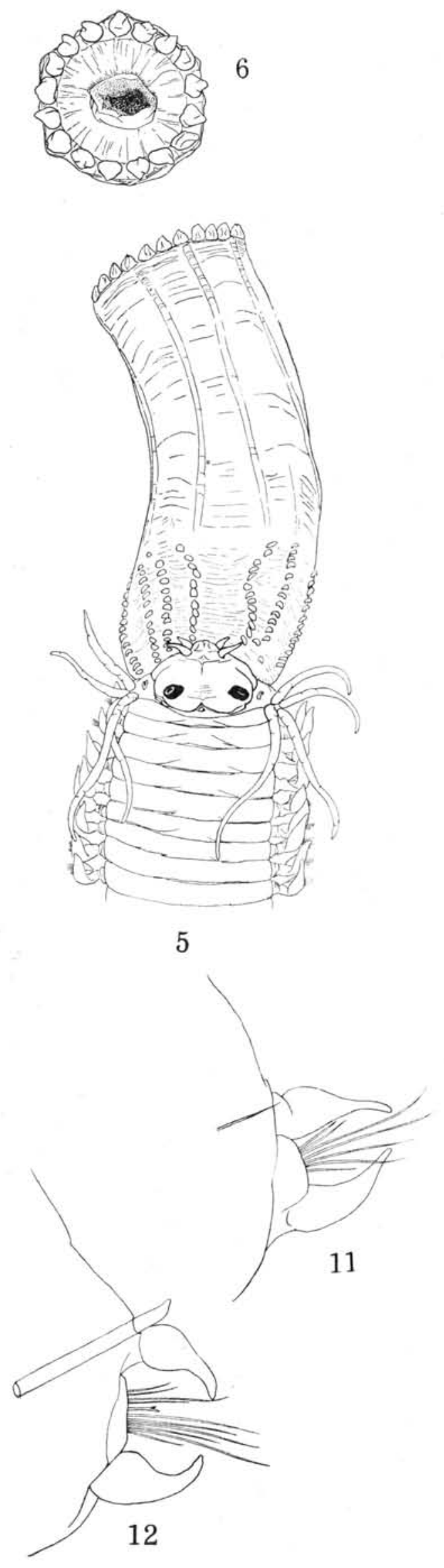
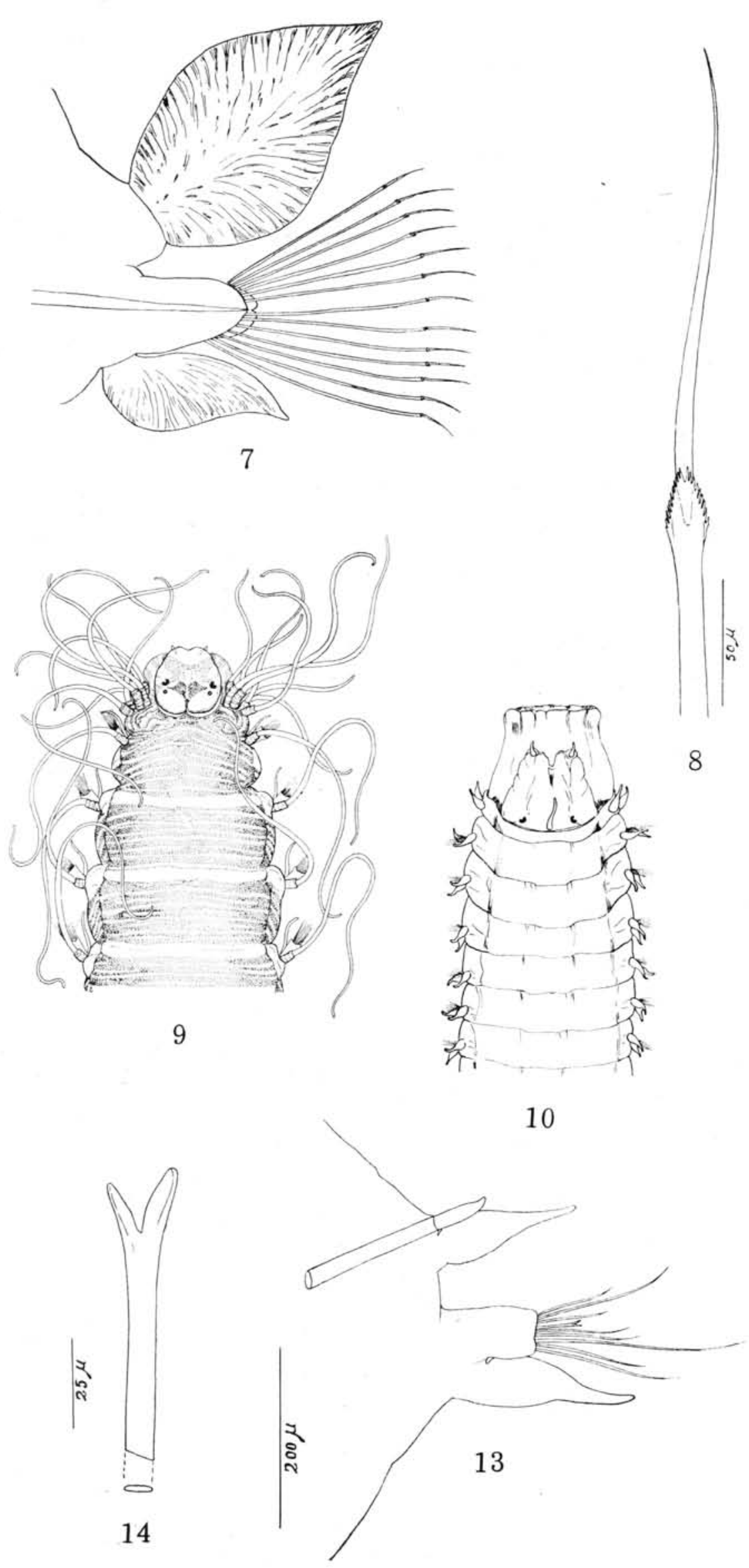
Nereis $s p$.

15. Regiāo anterior, com tromba evaginada; vista dorsal. 16. Regiâo anterior, face ventral. 17. Pé da região mediana (100.o setígero). 18. Cerda composta espinigera. 19. Cerda composta falcígera homogonfa, do felxe dorsal dos segmentos medianos e posteriores. 20. Cerda composta falcigera heterogonfa, dos feixes ventrais. (Fig. 18 a 20 na mesma escala).

Glycera longipinnis Grube

21. Regiăo anterior, com tromba evaginada; vista lateral. 22. Detalhe das papilas da superficie da tromba. 23. Dente ("maxila"), isolado. 24. Pé da região anterior; vista posterior. 25. Pé da reglão mediana (50.0 setigero), com brânquia ("br") bem desenvolvida. Glycera americana Leidy

26. Dente ("maxila") isolado. 


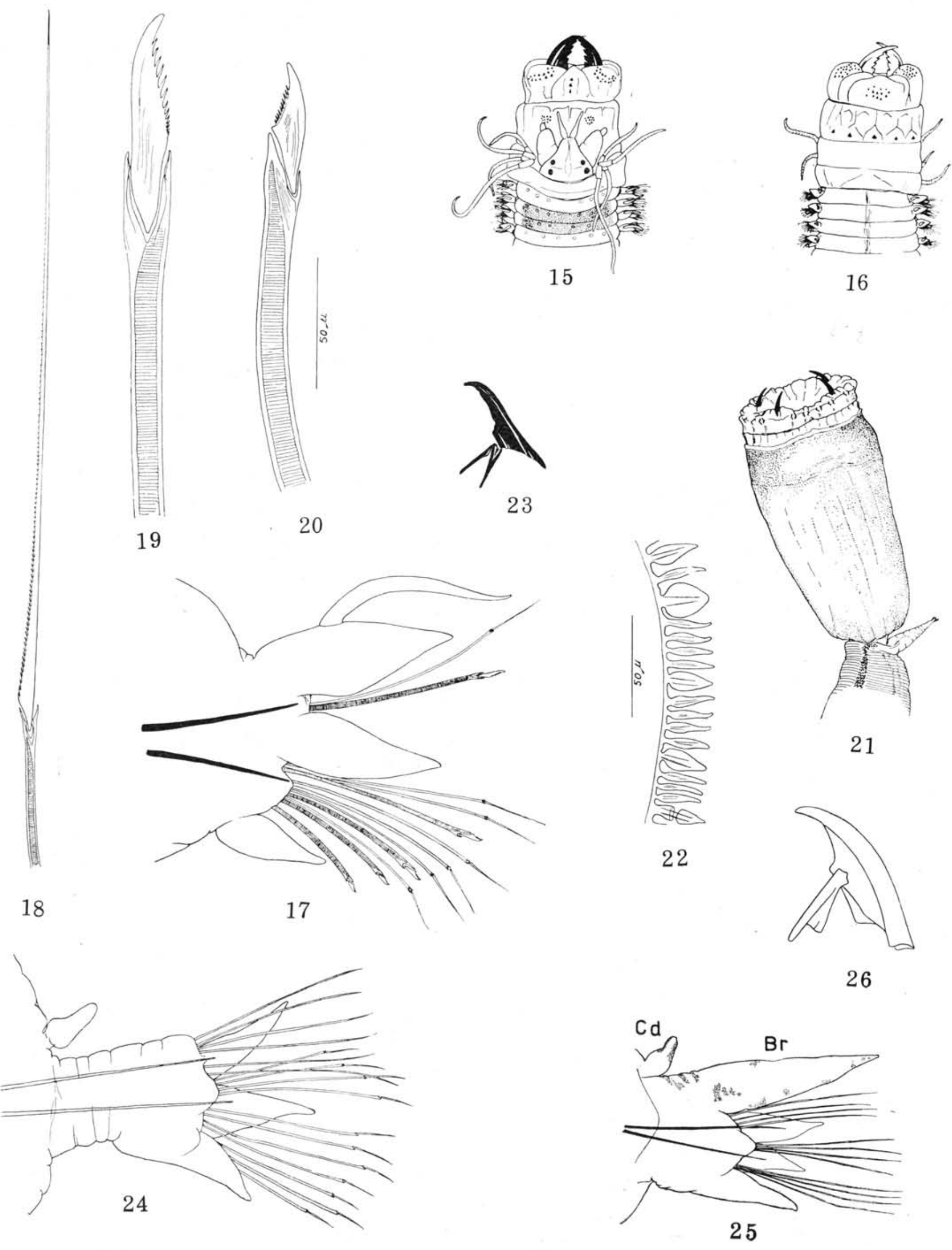


Nephtys squamosa Ehlers

27. Regiăo anterior, com tromba evaginada; vista dorsal. 28 Extremidade da tromba: vista frontal. 29. Quatro segmentos medianos (37.0-40.0); vista dorsal. 30. Pé da região mediana ( 30.0 setigero). 31. Detalhe de algumas cerdas de um feixe dorsal: cerdas em fita e pequenas cerdas barradas.

Diopatra spiribranchis Augener

32. Regiāo anterior; vista dorsal. 33. Corte transversal de uma antena; próximo à base. 34. Disposiçāo das papilas na superficte da antena. 

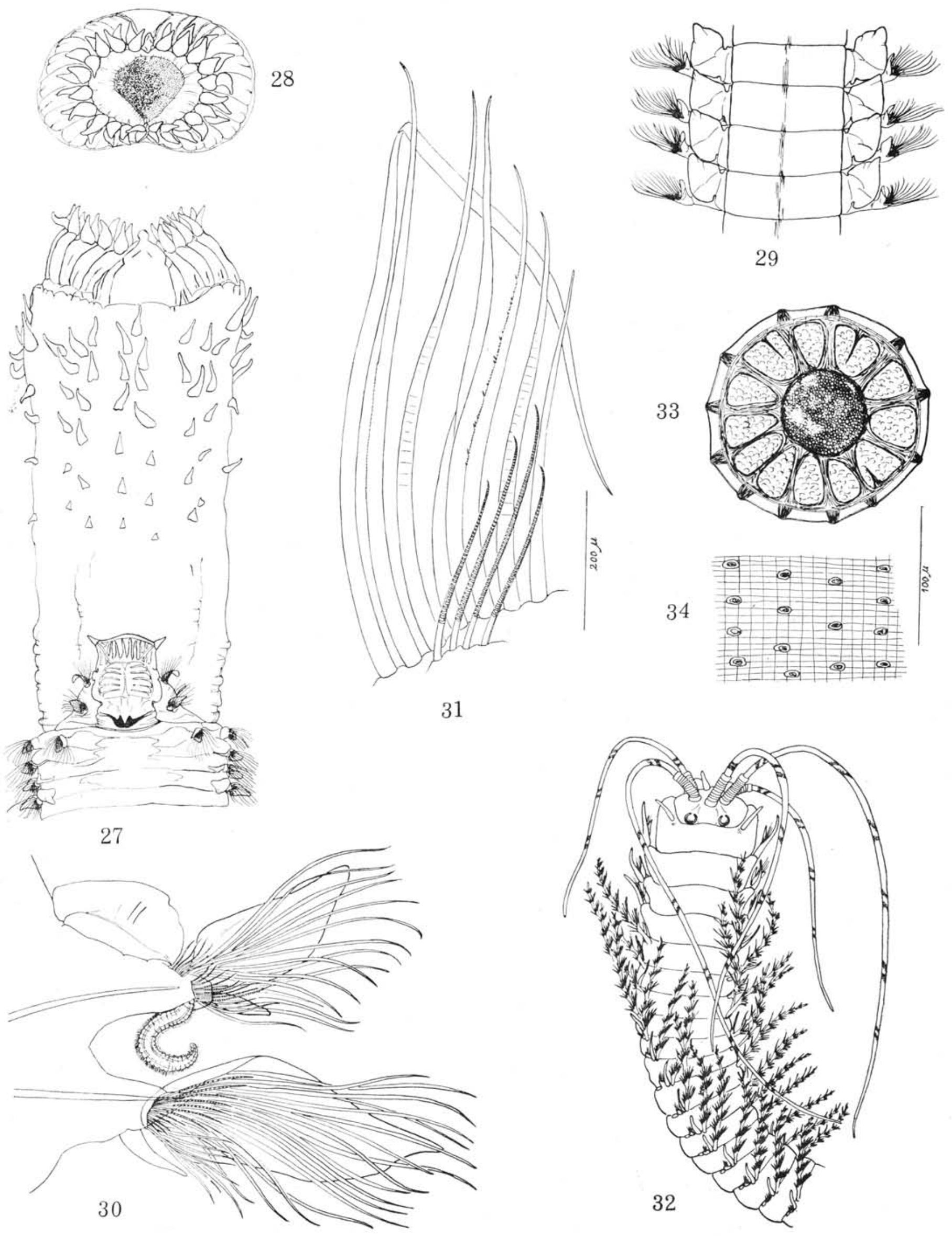

29

33
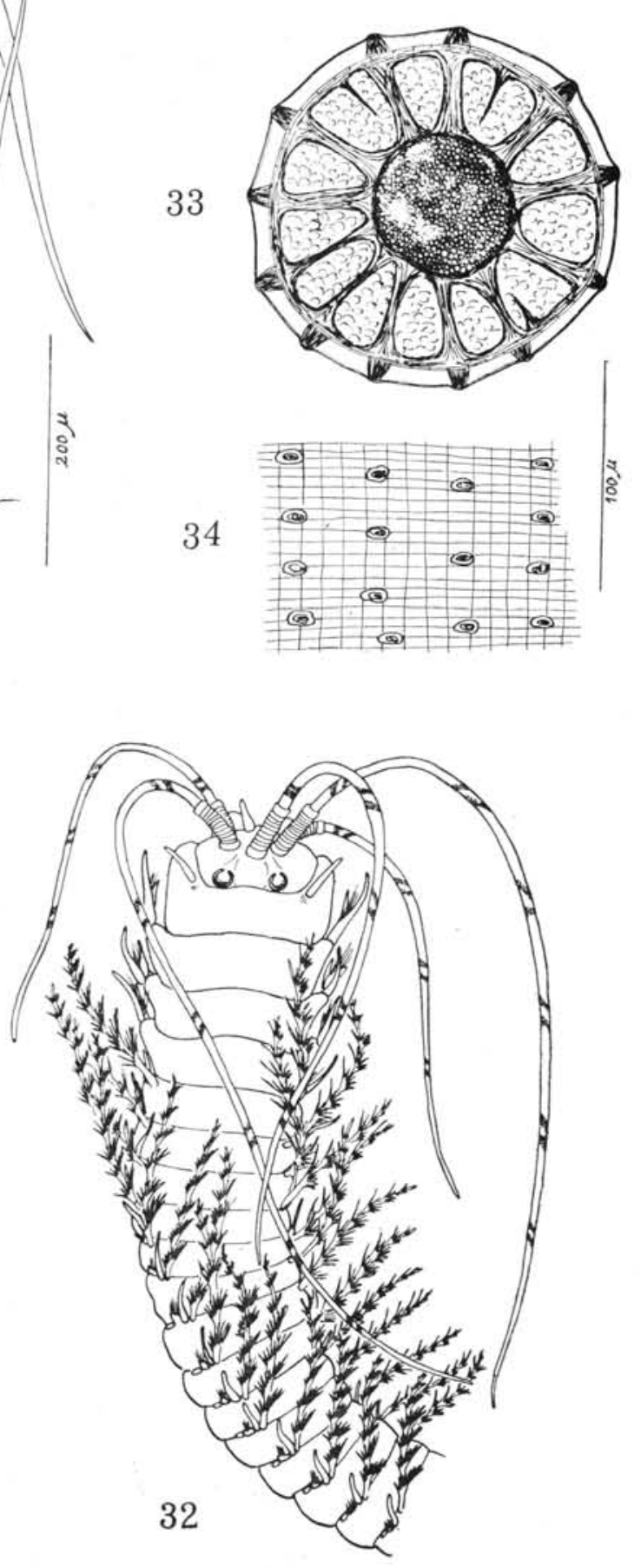

Bolm Inst. oceanogr. S Paulo, 19:57-130, 1970 
Onuphis litoralis Monro

35. Região anterior; vista dorsal. 36. Pé da região mediana ( 35.0 setígero), 37 . Cerda limbada, de um setígero da região anterior. 38. Gancho pseudo-composto, do 3.0 setígero; vista de perfil. 39. Artículo do gancho pseudo-composto; visto de frente. 40. Cerda composta cultriforme, de um setigero anterior (8.0). 41 . Cerda pectinada. 42. Gancho bi-dentado. 43. Dois aciculos. Eunice binominata Quatrefages

44. Regiāo anterior e mediana; vista dorsal. 45. Pigidio. 46. Pé de um setigero da regiáo anterior $\left(8^{\circ}\right)$. 47. Detalhe da extremidade de uma cerda limbada. 48. Cerda composta, setigeros anteriores. 49. Cerda pectinada, dos setigeros anteriores. 50. Gancho sub-acicular, tri-dentado, de um setigero mediano (30.0). (Fig. 47 a 50 na mesma escala). 

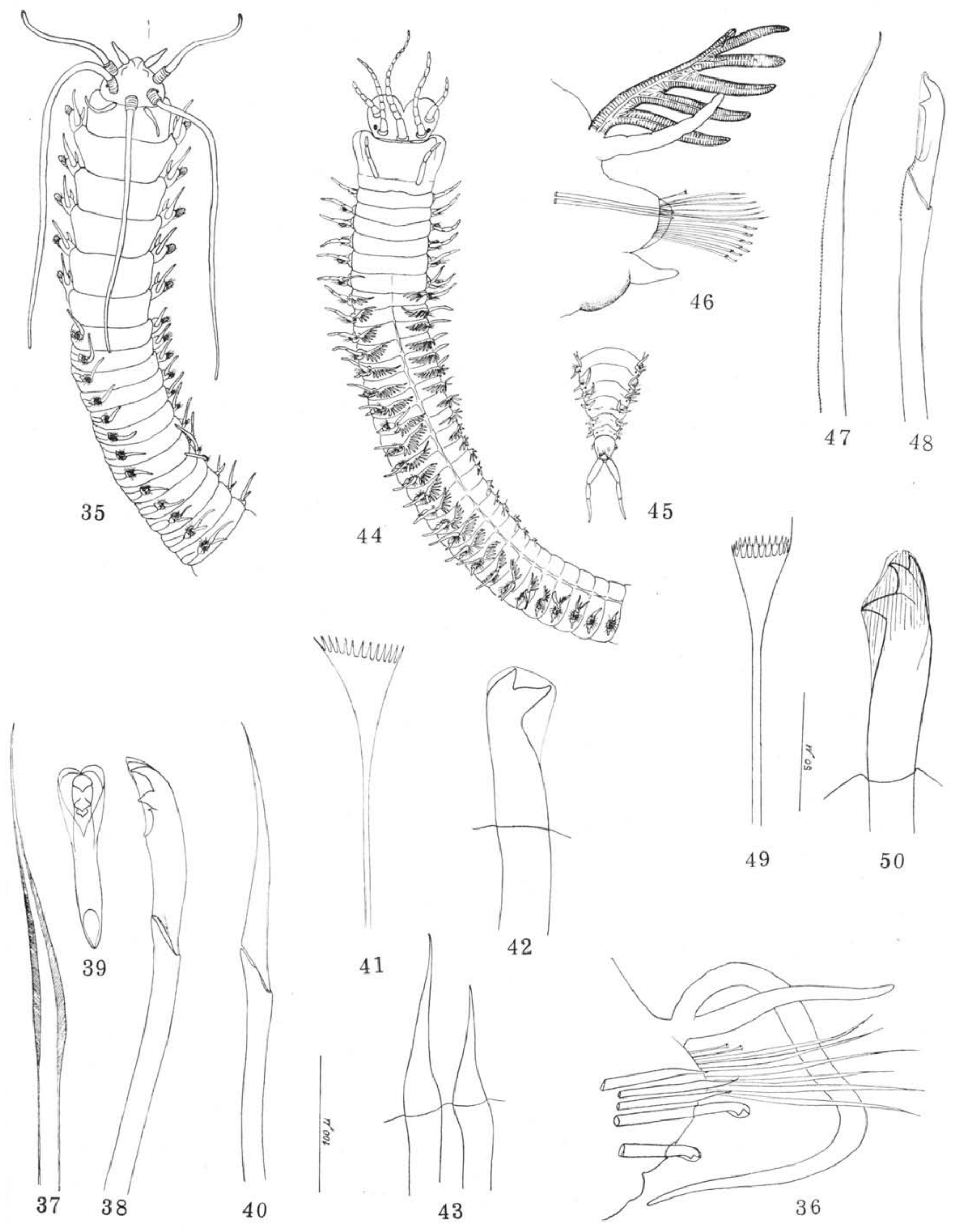
Eunice floridana (Pourialés)

51. Pé da regiâo anterior (10.0 setigero). 52. Pé da região mediana (45.0 setigero), 53. Cerda composta. 54. Maxilas. Eunice tridentata Ehlers

55. Cerda composta "tri-dentada" integra. 56 e 57. Cerdas compostas presumlvelmente erodidas em parte. 58. Cerda composta, do tipo mais simples.

Eunice (Nicidion) cariboea Grube

59. Pé đa regiāo mediana. 


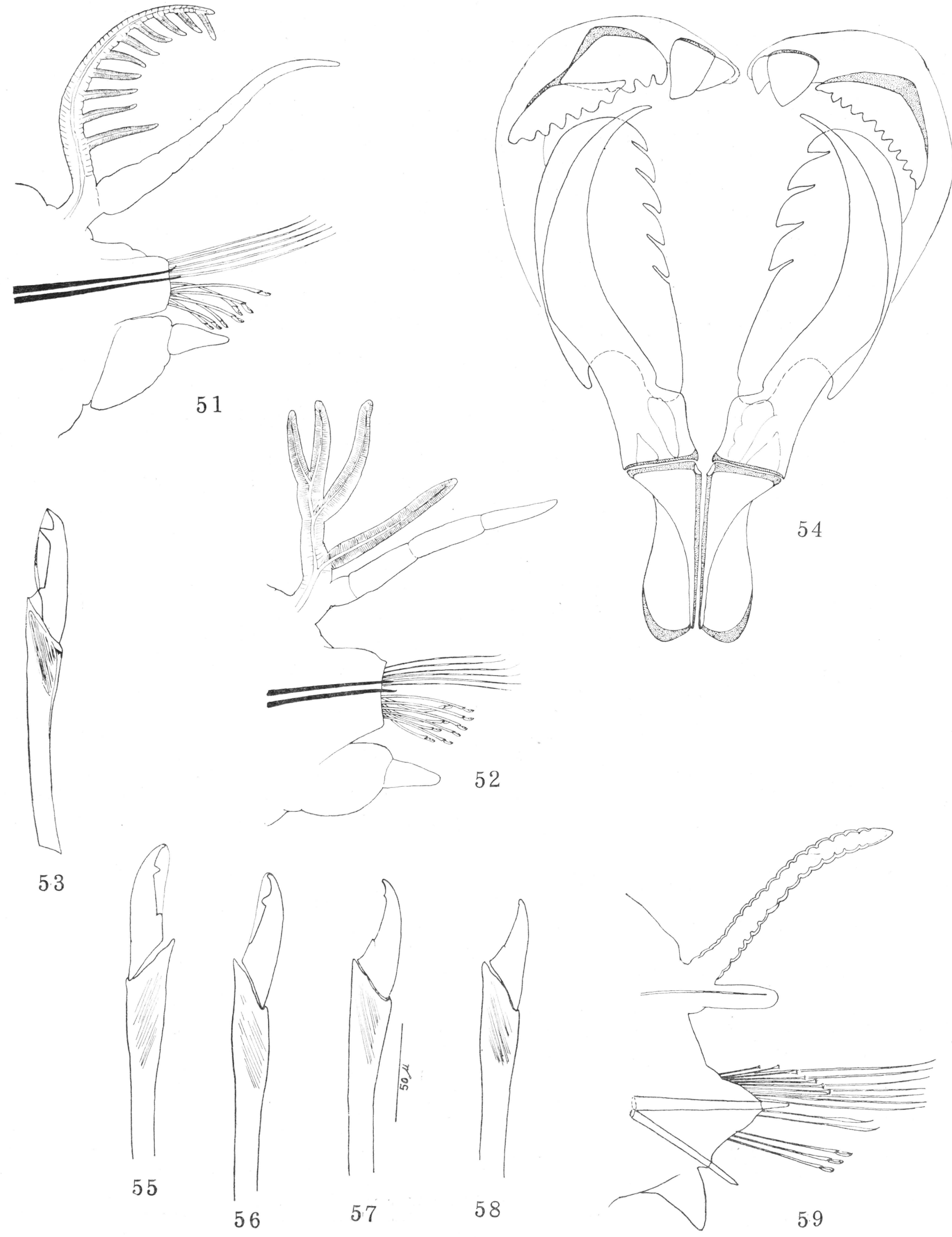


Eunice longicirrata Webster

60. Regiåo anterior; vista dorsal. 61. Maxilas. 62, Mandíbulas. (Fig. 61 e 62 na mesma escala). 

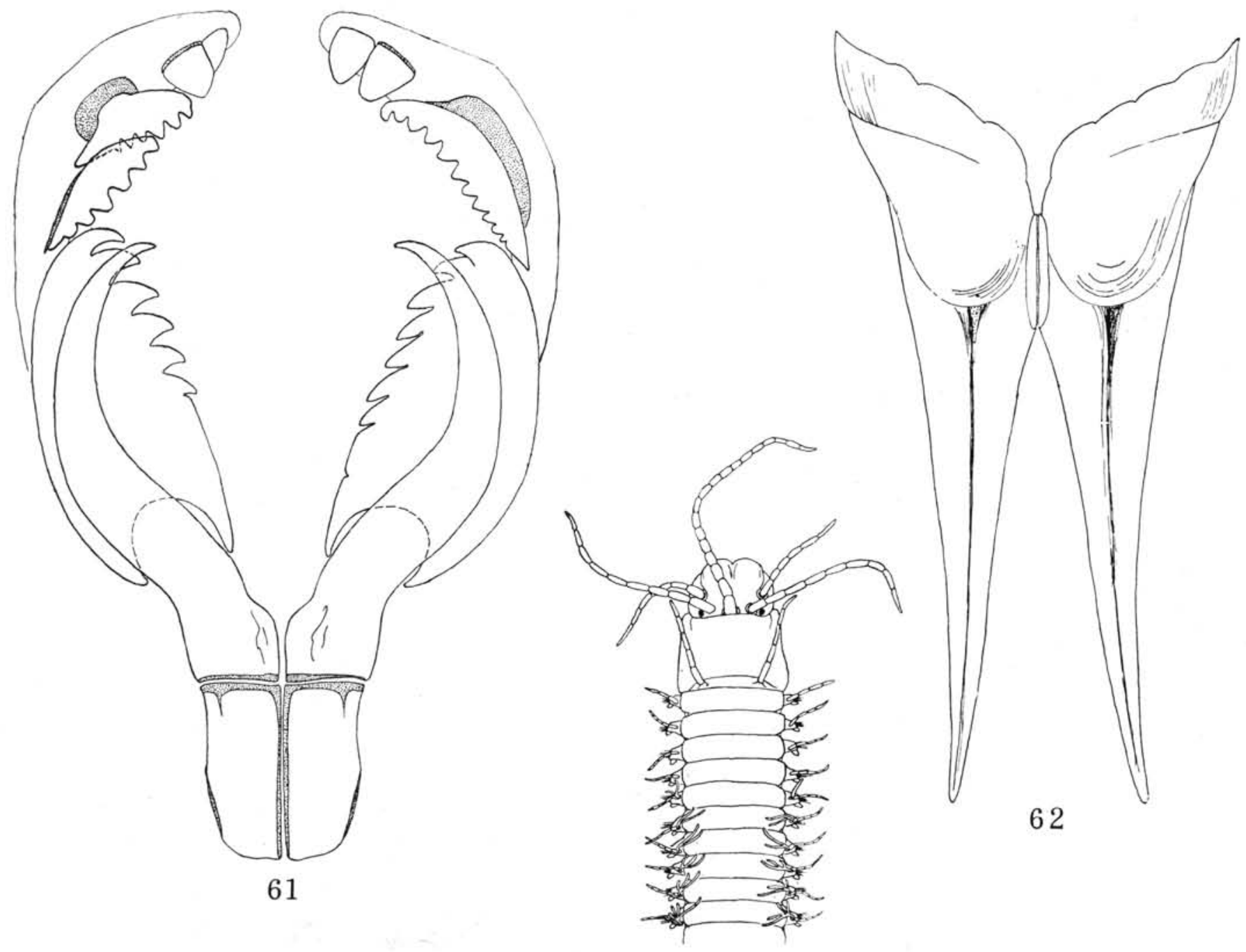

60 
Marphysa regalis Verrill

63. Regiăo anterior; vista dorsal. 64. Pé da regiâo anterior (5.0 branquial). 65 . Pé da regiāo mediana (50,0 setigero). 66. Pé da região posterior. 67. Maxilas. 68. Mandibulas. 


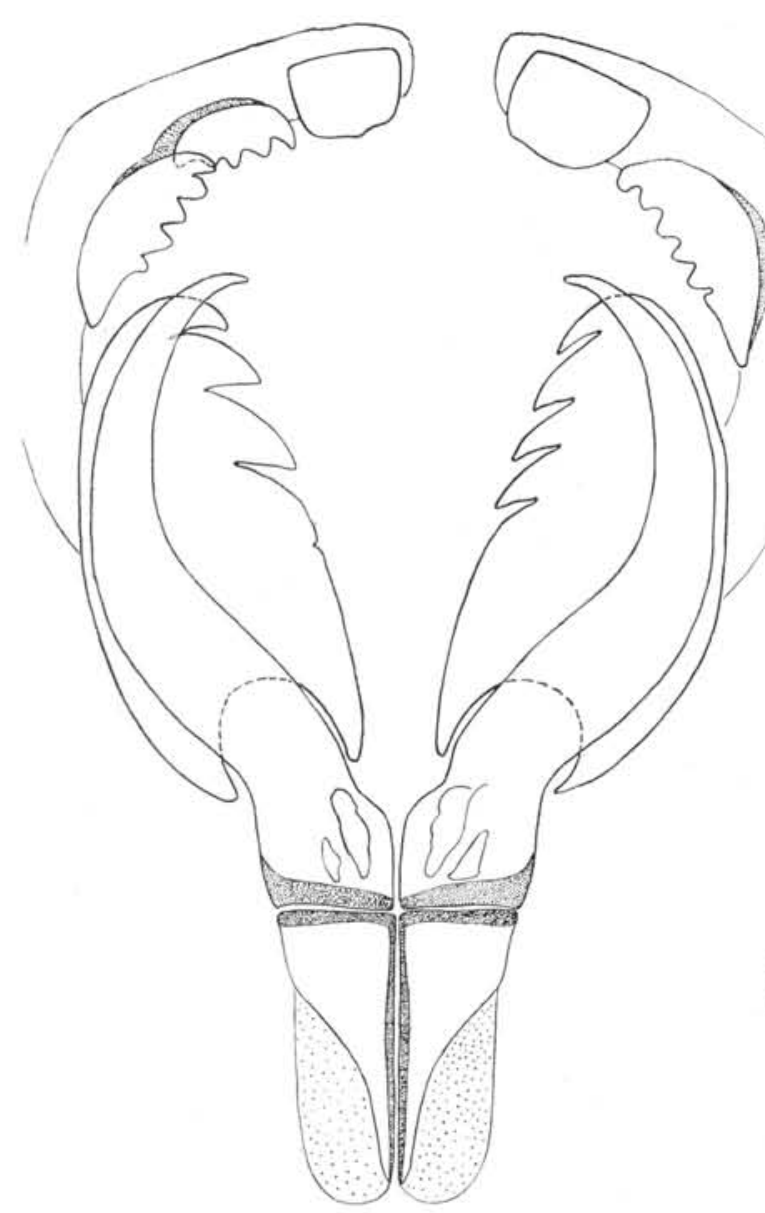

67
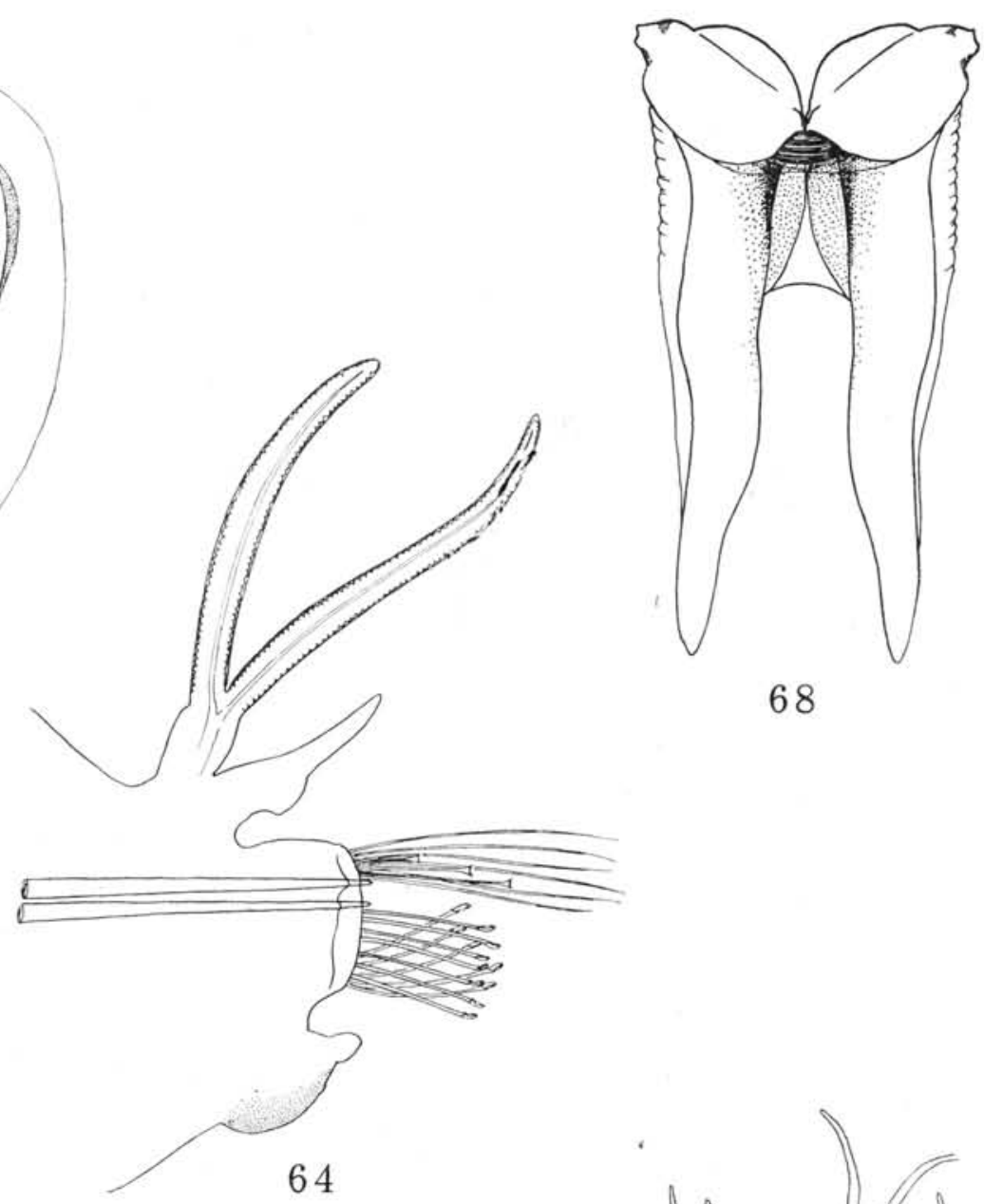

68

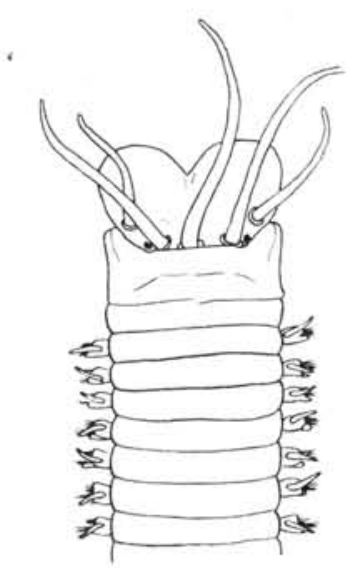

63
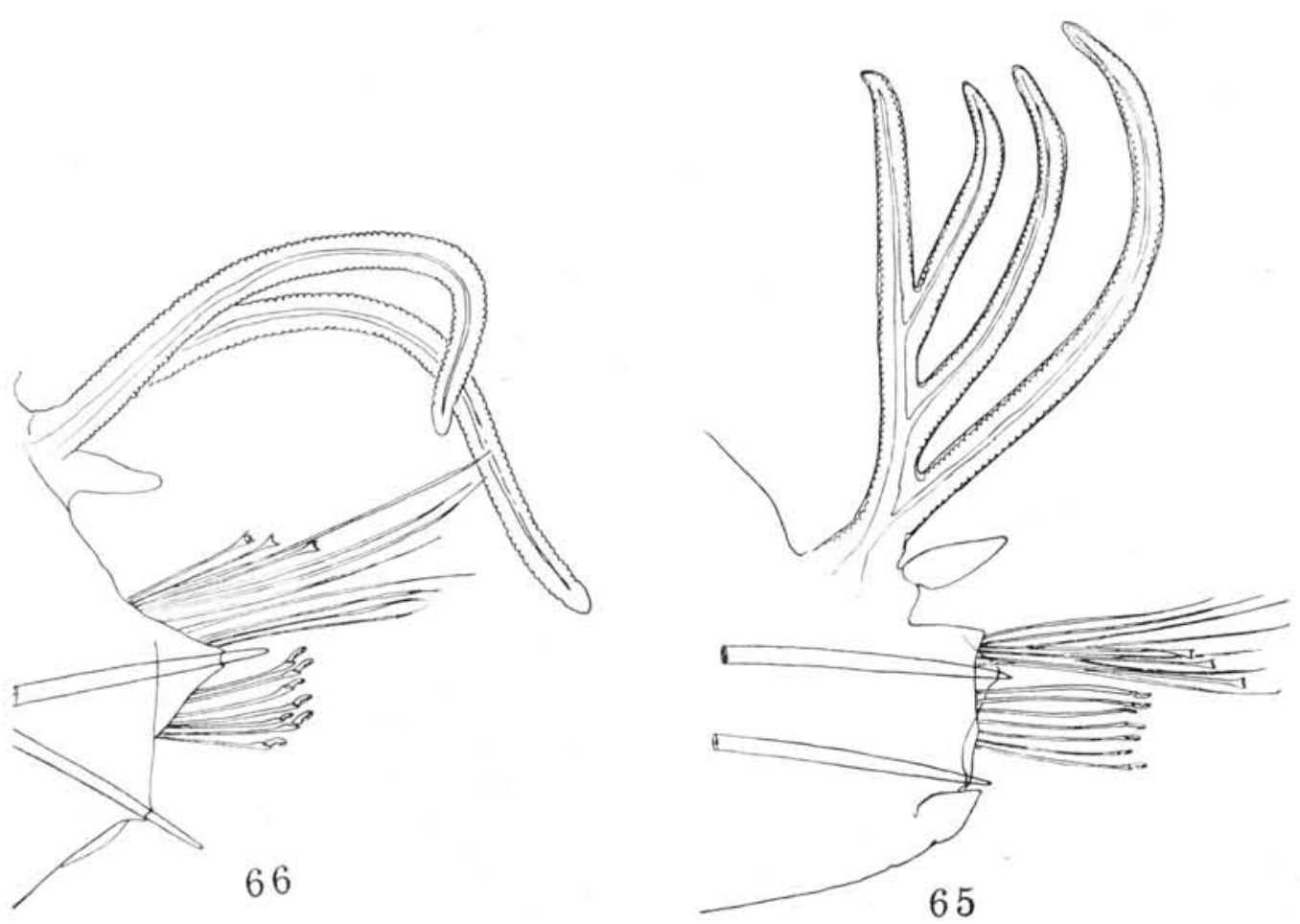

Bolm Inst. oceanogr. S Paulo, 19:57-130, 1970 
Scoloplos agrestis sp. nov.

69. Regiăo anterior; vista dorsal. 70. Região anterior (4.0 a 12.0 setígeros); vista lateral. 71. Pé de um setígero torácico anteríor $\left(3^{\circ}\right), 72$. Pé de um setígero torácíco mediano $(10.0)$. 73. Pé de um setigero abdominal anterior. 74. Cerda acícular de um setigero torácico anterior. 75. Cerda acicular de um setigero torácíco mediano. 76. Cerda capilar. 77. Detalhe de uma cerda capilar. (Fig. 74 e 76 na mesma escala). 

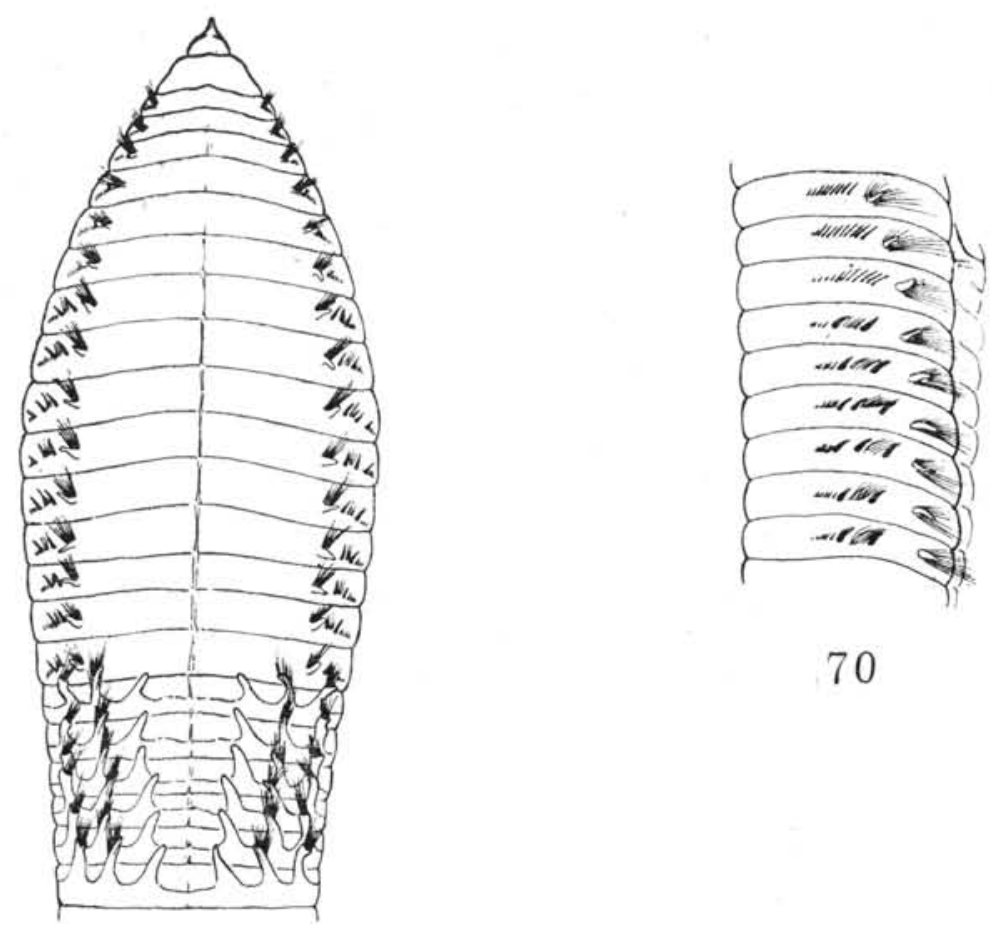

70

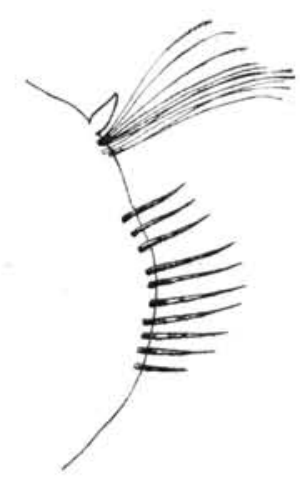

71

69
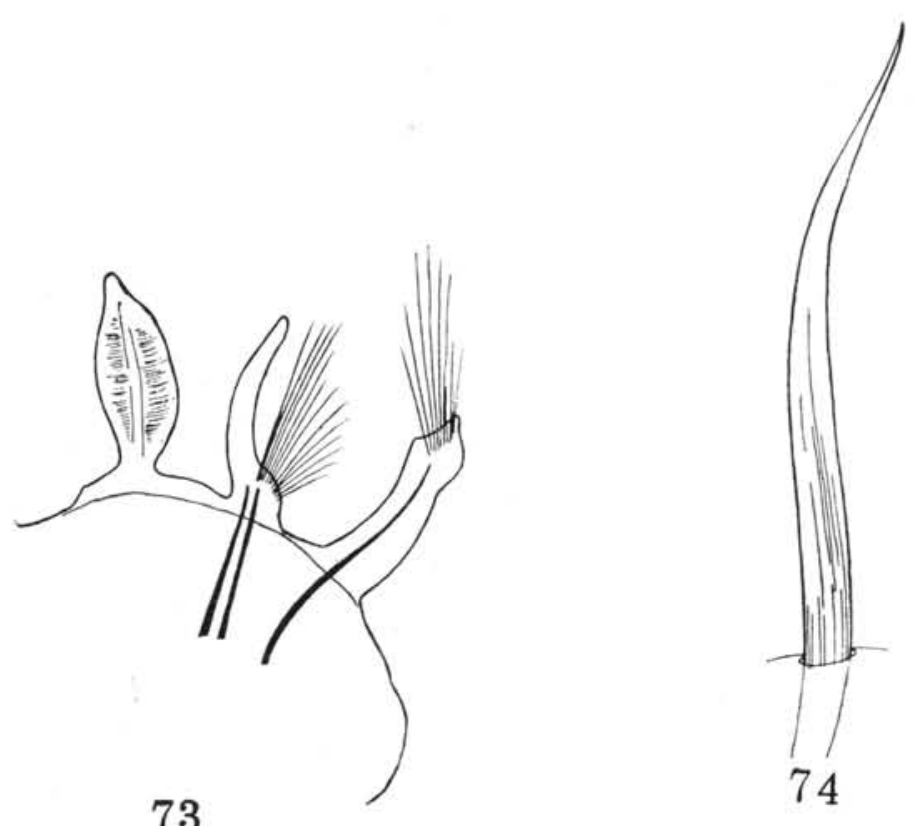

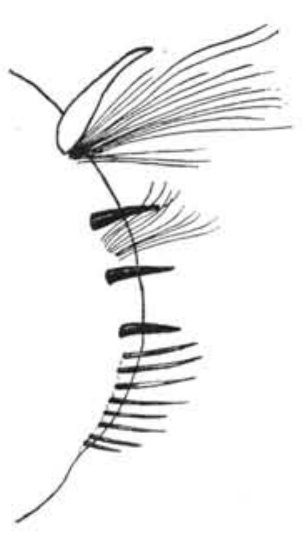

72

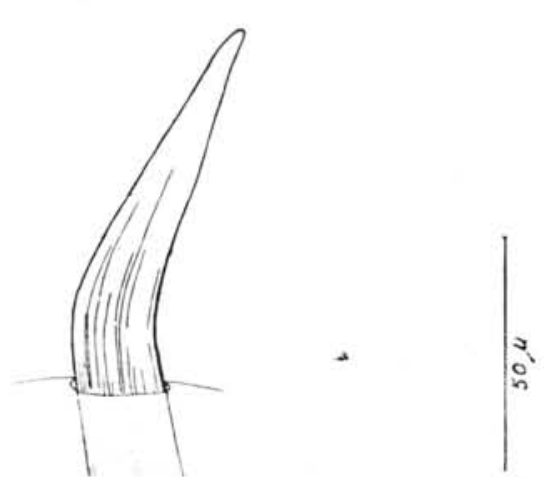

75

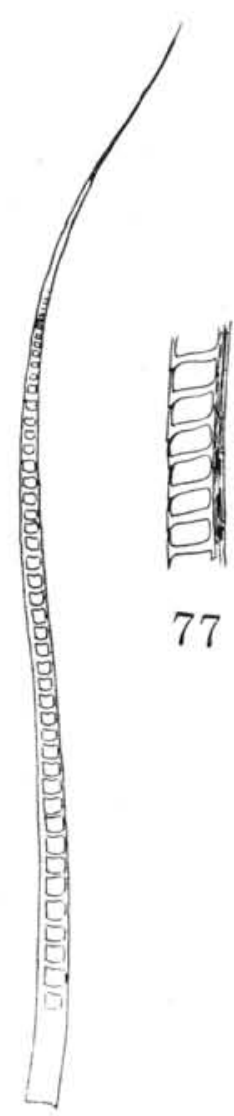

76

Bolm Inst. oceanogr. S Paulo, 19:57-130, 1970 
Piromis sp.

78. Duas cerdas aciculares de um setigero mediano.

Pherusa scutigera (Ehlers)

79. Animal total; vista dorsal. 80. Região anterior; vista dorsal. 81. Cerda capilar segmentada, dos primeiros setigeros. 82. Cerdas aciculares dos setigeros da região mediana e posterior. 83. Detalhe da região posterior.

Armandia maculata (Webster)

84. Regiảo anterior; vista lateral. 85. Região posterior; vista ventral. Armandia $s p$.

86. Regiảo anterior; vista lateral. Sternaspis capillata Nonato

87. Regiăo posterior; vista ventral. 88. Detalhe das brânquias e das papilas filiformes. 

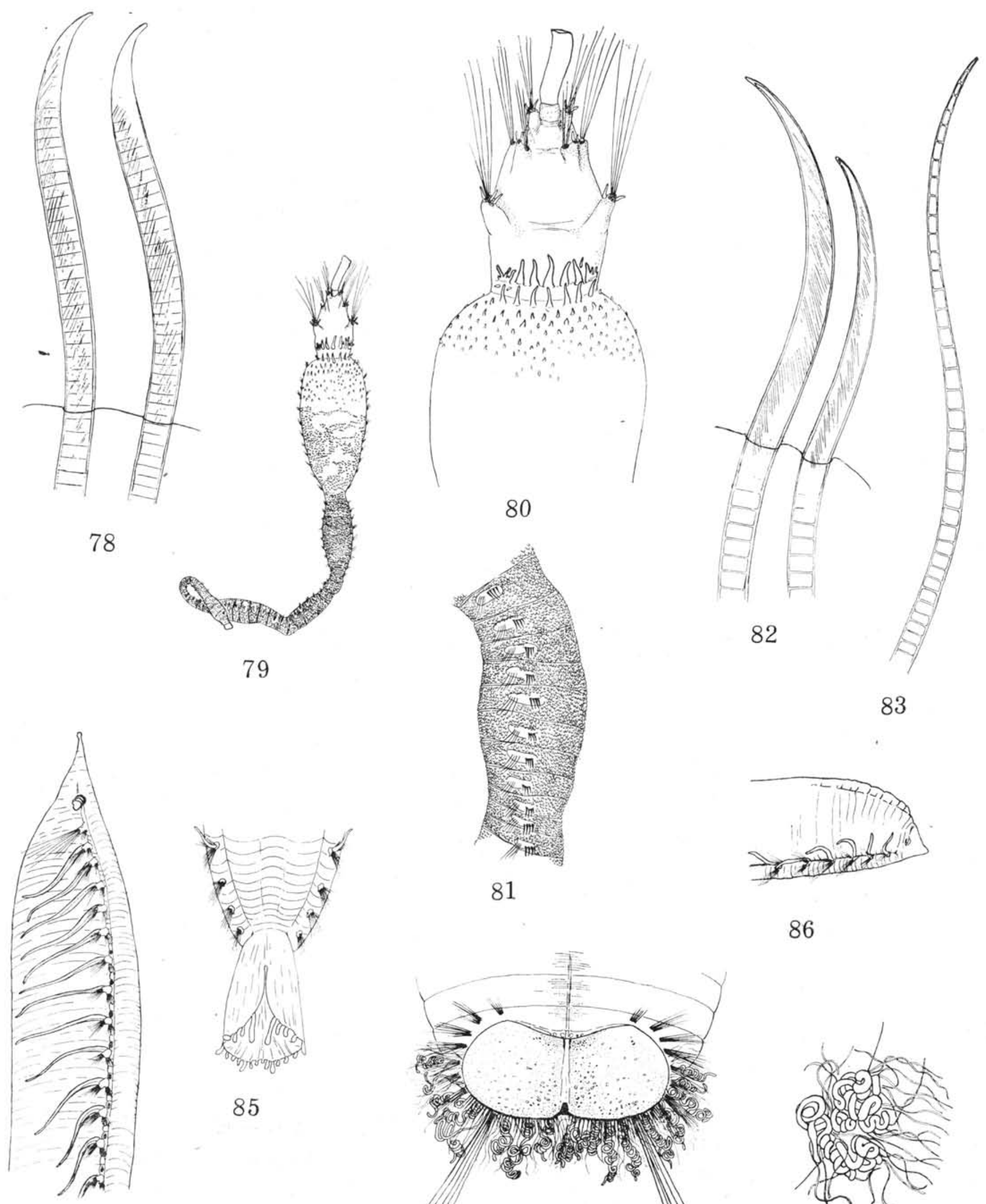

81

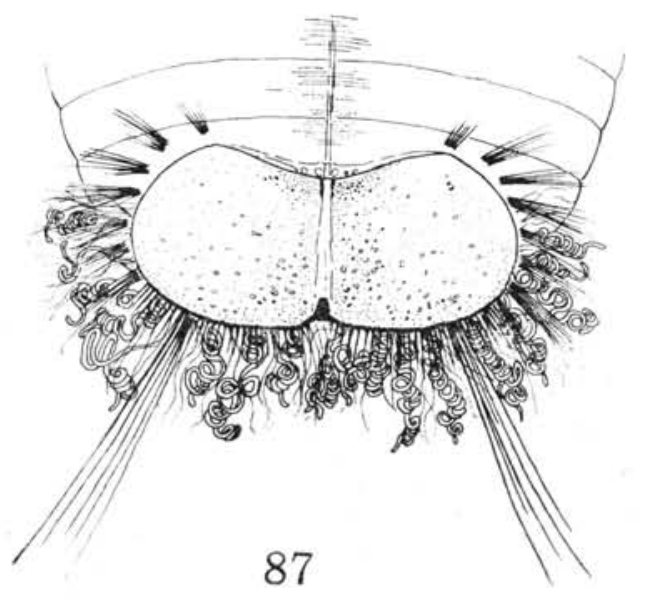

86

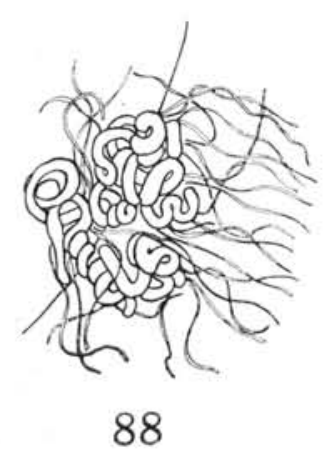

Bolm Inst. oceanogr. S Paulo, 19:57-130, 1970 
Streblosoma cf. bairdi (Malmgren)

89. Pé da regiăo anterior. 90 e 91 . Uncinus, de frente e de perfill.

Hypsicomus circumspiciens Ehlers

92. Região anterior; vista lateral. 93. Região anterior; vista dorsal (penacho branquial parcialmente cortado). 94. Cerda do "colar" (1.0 setígero). 95. Cerda espatulada, do ramo dorsal de um setígero torácico. 96. Cerda "en pioche" do ramo ventral, do mesmo setigero. 97 e 98. Cerdas espatuladas, de um setigero abdomínal. 99. Uncinus de um setigero torácico. 100. Uncinus de um setígero abdominal. (Fig. 94 a 100 na mesma escala).

Megalomma bioculatum (Ehlers)

101. Região anterior; vista dorsal. 

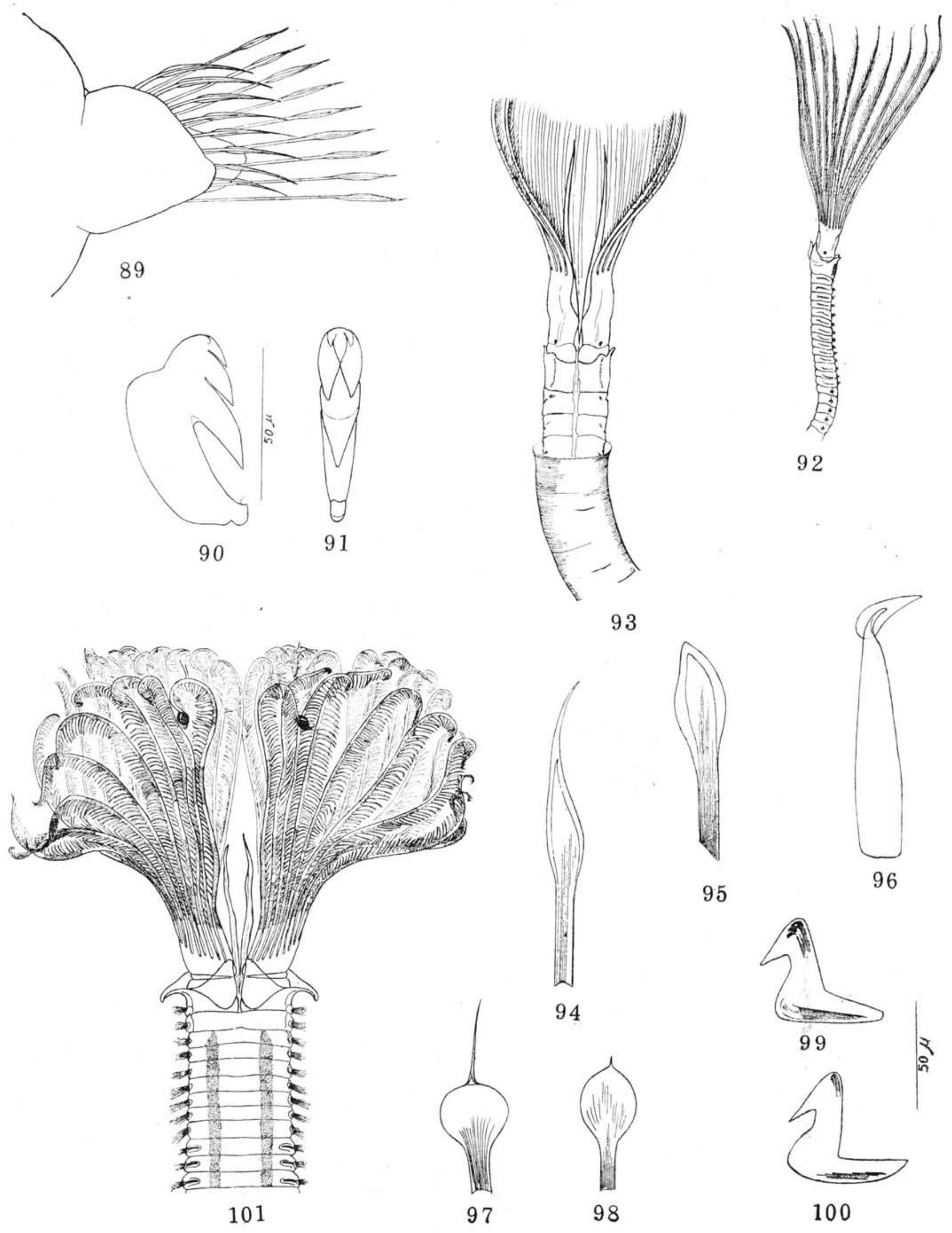

Bolm Inst. oceanogr. S Paulo, 19:57-130, 1970 
Crucigera websteri Benedict

102. Opérculo. 103. Cerda em baioneta, do $1^{\circ}$ setigero. 1C4. Cerda em espátula, dos primeiros setigeros abdominais. 105. Fragmento de tubo.

Hydroides californicus Treadwell

106. Opérculo. 107. Cerda em baioneta, do 1.0 setígero. 108. Uncinus torácico. 109. Uncinus abdominal.

Vermiliopsis acanthophora Augener

110. Opérculo. 111. Uncinus torácico. 


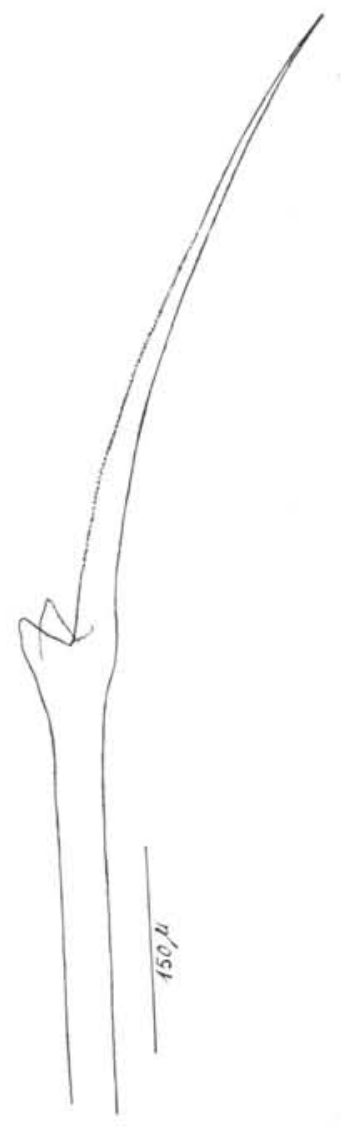

103
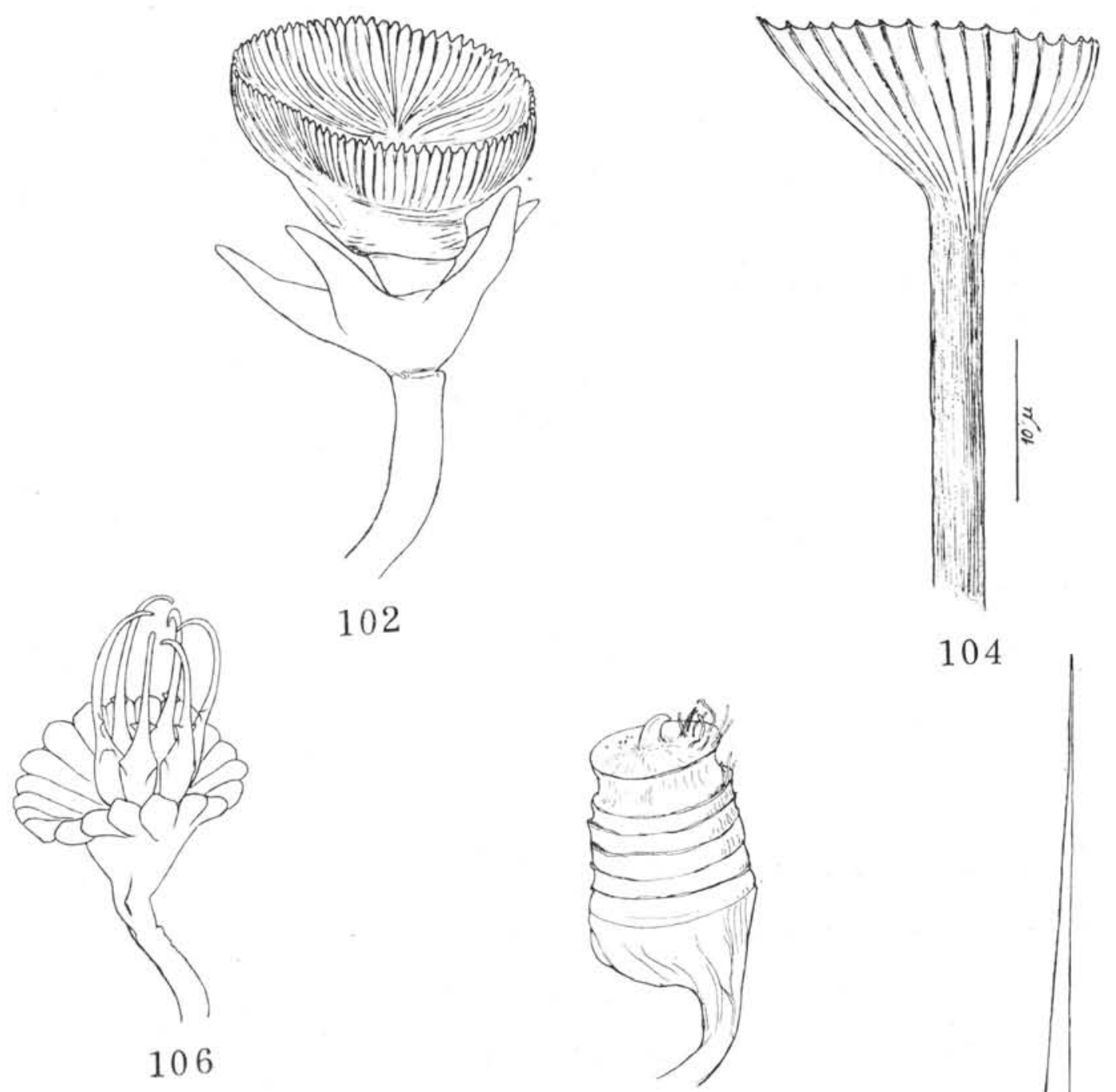

104

106
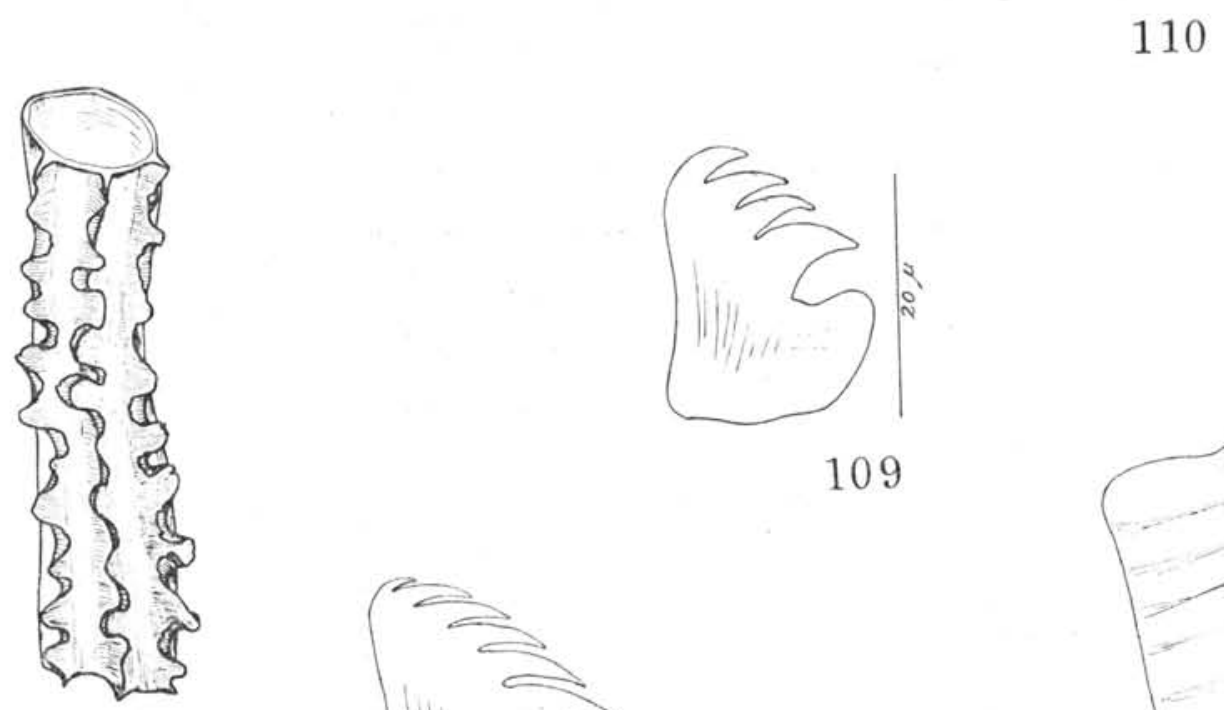

105

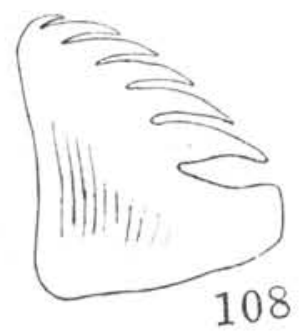

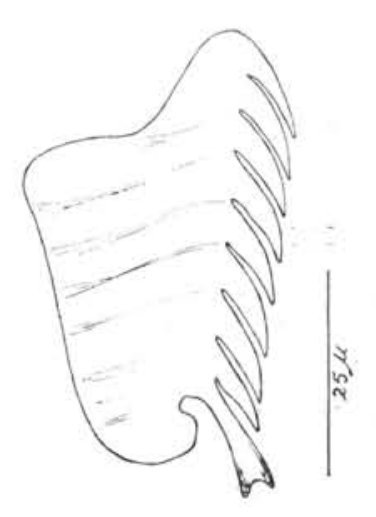

111

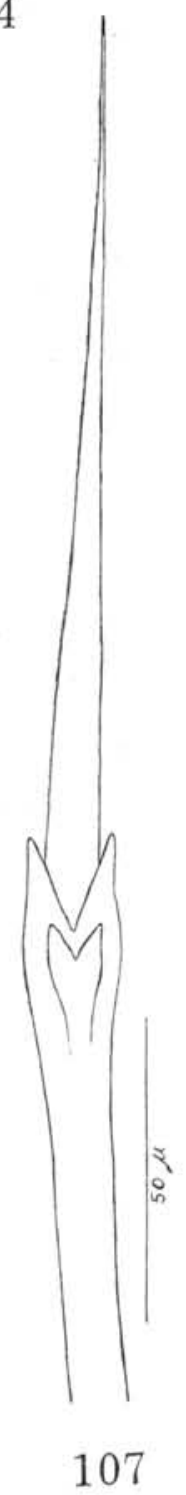




\section{RESUMO}

N'um trabalho anterior (Nonato \& LuNa, 1969) discutimos as espécies de poliquetas de escama que fazem parte de uma coleção proveniente de dragagens executadas pelo Laboratório de Ciências do Mar da Universidade Federal de Pernambuco, no Nordeste do Brasil.

No atual, são tratadas as espécies desprovidas de escamas, em número de 71 .

Informaçoes sôbre a área amostrada estão contidas nos trabalhos de Cavalcanti \& colab. e de MABESOONE \& TINOCO, 1967.

Espécies pequenas e delicadas que constituem parte ponderável das populacōes bentônicas foram muito raras nesta área. Isto pode ser devido a condicỗes eventualmente adversas ou, muito mais provàvelmente, é conseqüência de sua destruição durante a coleta e triagem.

Os fundos duros predominantes, com superfície irregular e constituídos em grande parte por blocos ou cascalho de algas calcárias e corais, tornam particularmente árdua a amostragem biológica. Nessas condições é difícil preservar a integridade de sêres de corpo delicado como os poliquetas, da ação trituradora, dentro dos aparelhos de coleta.

Devemos ter em conta essa circunstância ao avaliar a densidade aparente da fauna. Os poliquetas não devem ser tão pouco freqüentes como indica o resultado da prospecção atual.

Acreditamos que o uso de melhores técnicas permitirá apreciar a sua verdadeira densidade e conhecer melhor sua distribuição. A pesca noturna, com luz submersa, por exemplo, poderá ser um excelente método para atrair espécies do substrato ou de habitats de outra forma inaccessiveis.

Das 71 espécies, apenas uma foi considerada como nova para a ciência. Scoloplis agrestis sp. nov. assemelha-se a S. robustus Rullier e a S. madagascarensis Fauvel, diferindo de ambas pelo número de setígeros torácicos e pelo número reduzido de cerdas aciculares dos neuropódios torácicos.

Os Eunicea são o grupo melhor representado, com 26 espécies, das quais a mais comum é Eunice longicirrata Webster (108 exemplares em 19 estações).

Diopatra spiribranchis Augener e Hypsicomus elegans Webster são consideradas boas espécies.

Sòmente dois Flabelligerideos foram capturados em tôda a área; um dêles é um espécimem bem conservado de Pherusa scutigera (Ehlers) e o outro um Piromis sp.

A maior parte das espécies desta coleção é constituída por formas semelhantes às encontradas na região das Antilhas, como, aliás, seria de se esperar. Porém, algumas aproximam-se de espécies do Pacífico e do fndico, como é o caso de Glycera longipinnis Grube, Onuphis litoralis Monro e Vermiliopsis acanthophora Augener, cujas características concordam perfeitamente com as descrições a que tivemos acesso.

\section{BIBLIOGRAFIA}

ANDREWs, E. A

1891. Report upon the Annelida Polychaeta of Beaufort, North Carolina. Proc. U. S. natn. Mus., vol. 14, p. 277-302, est. 12-18.

AUGENER, $\mathrm{H}$.

1906. Reports on the results of dreadging, under the supervision of Alexander Agassiz, in the Gulf of Mexico and the Caribbean Sea, and on the east coast of the United States, 1877 to 1880 , by the U.S.S. Coast Survey Steamer "Blake". Westindische Polychaeten. Bull. Mus. comp. Zool. Harv., vol. 43, n. ${ }^{\circ}$ 4, p. 91-106, 8 ests.

1914. Polychaeta Sedentaria. Fauna Südwest-Aust., vol. 5, Lief. 1, p. 1-170, 1 est.

1918. Polychaeta. Beitr. Kennt. Meeresfauna Westafr., vol. 2, Lief. 2, p. 67-625, 6 ests.

1922. Ueber litorale Polychaeten von Westindien. Sber. Ges. naturf. Freunde Berl., n. $3-5$, p. $38-53$.

1931 Die bodensässigen Polychaeten nebst einer Hirudinee der Meteor-Fahrt. Mitt. zool. StInst. Hamb., vol. 44, p. 279-313, 11 figs.

1933. Polychaeten aus den zoologischen Museen von Leiden und Amsterdam. II. Zoöl. Meded. Leiden, vol. 16, p. 261-282, 31 figs.

BENEDICT, J. E

1887. Descriptions of ten species and one new genus of annelids from the dredgings of the U.S. Fish Comm. Steamer "Albatross". Proc. U.S. natn. Mus., vol. 9, p. $547-553$, est. $20-25$.

Berkeley, E. \& Berkeley, C.

1939. On a collection of Polychaeta, chiefly from the west coast of Mexico. Ann. Mag. nat. Hist., ser. 11, vol. 3, p. 321346,12 figs.

1941. On a collection of Polychaeta from southern California. Bull. Sth Calif. Acad. Sci., vol. 40 , pt. 1, p. 16-60, 18 figs.

1948. Annelida, Polychaeta errantia. Can. Pacif. Fauna, n.o 9, (1), p. 1-100, 160 figs.

Bush, K. J.

1904 Tubicolous annelids of the tribes Sabellides and Serpulides from the Pacific Ocean. Harriman Alaska Exped., vol. 12 , p. $169-355$, est. $21-44$

Cavalcanti, L. B. \& outros

1967. Shelf off Alagoas and Sergipe (Northeastern Brazil). 1. Introduction. Trabhs Insc. oceanogr. Univ. Fed. Recife, vol $7 / 8$, p. $137-149$.

Chamberlin, R. V.

1919. The Annelida Polychaeta. Mem. Mus, comp. Zool. Harv., vol. 48, p. 1-514, est. $1-80$.

Crossland, C.

1924. Polychaeta of tropical East Africa, the Red Sea and Cape Verde Islands, collected by Cyril Crossland and of the Maldive Archipelago collected by Professor Stanley Gardiner, M. A., F. R. S. The Lumbriconereidae and Staurocephalidae. Proc. zool. Soc. Lond., p. 1-106, 126 figs.

DAY, J. H.

1961. The polychaete fauna of South Africa Part 6. Sedentary species dredged off Cape coasts with a few new records from the shore. J. Linn. Soc., Zool., vol. 44 , p. $463-560$, fig. $1-18$. 
1967. Polychaeta of Southern Africa. Part 1. Errantia. London, British Mus. (Nat. Hist.), Publ. n. ${ }^{\circ} 655$, viii +458 p., 109 figs.

1967a. Polychaeta of Southern Africa. Part 2. Sedentaria. London, British Mus. (Nat. Hist.), Publ. n. ${ }^{\circ} 656$, xvii +419 p., 87 figs.

DEW, B.

1959. Serpulidae (Polychaeta) from Australia. Rec. Aust. Mus., vol. 25, p. 19-56, fig. $1-21$.

EHLERS, E.

1868. Die Borstenwürmer nach systematischen Untersuchungen dargestellt. Leipzig, 748 p. 24 ests.

1887. Report on the annelids of the dredging expedition of the U.S. Coast Survey Steamer "Blake". Mem. Mus. comp. Zool. Harv., vol. 15 , vi +335 p. 60 ests.

1897. Polychaeten. Hamburger Magalhaenischen Sammelreise. Hamburg, Friedrichsen \& Co., 148 p. 9 ests.

1901. Die Polychaeten des Magellanischen und Chilenischen Strandes. Fetschr. Ges. Wiss. Götingen, Math.-Phys. Kl., p. 1232 , est. 1-25.

1908. Die Bodensässigen Anneliden aus den Sammlungen der deutschen TiefseeExpedition. Wiss. Ergegn. dt. TiefseeExped. "Valdivia", vol. 16, p. 1-167, 23 ests.

FAUCHALD, K

1969. A revision of six species of the flavusbidentatus group of Eunice (Eunicidae: Polychaeta). Smithson. Contr. Zool., n. ${ }^{\circ}$ 6 , p. $1-15$, fig. $1-15,1$ tab.

Fauvel, P. 1914.

Annélides polychètes non-pelagiques provenant des campagnes de l" "Hirondelle" et de la "Princesse-Alice" (1885-1910). Résult. Camp. scient. Prince Albert I, vol. 46 , p. $1-432,31$ ests.

1917. Annélides polychètes de l'Australie meridionale. Archs Zool. exp. gén., vol. 56, p. 159-278, 6 ests. 2 mapas.

1919. Annélides polychètes de Madagasgar, de Djibouti et du Golfe Persique. Archs Zool. exp. gén., vol. 58 , p. $315-473$, est. 15-17.

1923. Polychètes errantes. Faune Fr., vol. 5, p. 1-488, 188 figs.

1927. Polychètes sedentaires. Addenda aus Errantes, Archiannélides, Myzostomaires. Faune Fr., vol. 16, p. 1-494, 152 figs.

1932. Annelida Polychaeta of the Indian Museum, Calcutta. Mem. Indian Mus., vol. 12 , n. 1 , p. $1-262,9$ ests., 40 figs.

1947. Annélides polychètes du Nouvelle-Caledonie et les Isles Gambier. Faune Emp. fr., vol. 8, p. 1-108.

1953. Annelida. Polychaeta. The fauna of India, including Pakistan, Ceylon, Burma and Malaya. Allahabad, p. i-xii, 1-507, fig. 1-250.
Fauvel, P. \& Rullier, F.

1957. Nouvelle contribution à la faune des annélides polychètes du Sénégal. Bull. Inst. fr. Afr. noire, vol. 19 , sér. A, n. ${ }^{\circ} 1$ p. $24-96$; n. ${ }^{\circ} 2$, p. $373-399$.

1959. Annélides polychètes. Rés. Sci. Camp. Calypso, fasc. IV. Annls Inst. océanogr. Monaco, vol. 37, p. 143-205, fig. 5 .

1959a. Contribution à la faune des annélides polychètes du Sénégal et de Mauritanie. Bull. Inst. fr. Afr. noire, vol. 21, sér. A, pt. 1 , p. $477-533$, 1 fig.; pt. 2 , p. $934-987$, 7 figs

Gravier, C.

1908. Contribution à l'étude des annélides polychètes de la Mer Rouge (suite). Nouv. Archs Mus. Hist. nat. Paris, sér. 4, vol. 10 , p. $67-168$.

Grube, A. E.

1856. Annulata Oerstediana. Pt. 1, p. 44-62.

1877. Die von der Gazelle mitgebrachten Anneliden, zu denen noch zwei von Dr. Buchholz gesammelte kommen. Mber. dt. Akad. Wiss. Berl., p. 509-554.

1878. Annulata Semperiana. Beiträge zur Kenntniss der Annelidenfauna der Philippinen nach den von Herr Prof. Semper mitgebrachten Sammlungen. Mém. Acad. Sci. St. Petersburg., vol. 25, ix + 300 p., 15 ests.

HANSEN, G. A

1882. Recherches sur les annélides recuillies par M. le professeur Eduard van Beneden pendant son voyage au Brésil et à la Plata. Mém. Acad. r. Sci. Belg., vol. 44 , p. 1-29, est. 1-7.

HARTMAN, O.

1939. Polychaetous annelids. Pt. 1. Aphroditidae to Pisionidae. Allan Hancock Pacif. Exped., vol. 7, p. 1-156, 28 ests.

1940. Polychaetous annelids. Pt 2. Chrysopetalidae to Goniadidae. Allan Hancock Pacif. Exped., vol. 7, p. 173-287, 14 ests.

1942. The identity of some marine worms in the United States National Museum. Proc. U.S. Natn Mus., vol. 92, p. 101140, 15 figs.

1942a. A review of the types of polychaetous annelids at the Peabody Museum of Natural History, Yale University. Bull. Bingham oceanogr. Coll., vol. 8, n. ${ }^{\circ}$, p. 1-98, 161 figs.

1942b. Report on the scientific results of the "Atlantis" expeditions to the West Indies under the joint auspices of the University of Havana and Harvard University. Mems Soc. cub. Hist. nat. "Felipe Poey", vol. 16, n. ${ }^{\circ}$, p. 89-104, est. 8-9.

1944. Polychaetous annelids. Allan Hancock Atlant. Exped., n. 3 , p. $1-33,2$ ests.

1944a. Polychaetous annelids. Pt. 5. Eunicea. Allan Hancock Pacific Exped., vol. 10, n. ${ }^{\circ} 1$, p. $1-238,18$ ests. 
1945. The marine annelids of North Carolina. Bull. Duke Univ. Mar. Stn., n. ${ }^{\circ} 2$, p. 154,10 ests., 2 mapas.

1947. Polychaetous annelids. Pt. 8. Pilargiidae. Allan Hancock Pacif. Exped., vol 10 , n. 5 , p. $482-523$, est. $59-63$.

1948.

The marine annelids erected by Kinberg with notes on some others types in the Swedish State Museum. Ark. Zool., vol. $42 \mathrm{~A}$, n. ${ }^{\circ} 1$, p. $1-137$, est. $1-18$.

1950 Polychaetous annelids. Goniadidae, Glyceridae, Nephtyidae. Allan Hancock Pacif. Exped., vol. 15, n. ${ }^{\circ}$ 1, p. 1-181, 19 ests., 3 figs.

1951. The littoral marine annelids of the Gulf of Mexico. Publs Inst. mar. Sci. Univ. Tex., vol. 2, p. 7-124, 27 ests.

1956. Polychaetous annelids erected by Treadwell, 1891 to 1948 , together with a brief chronology. Bull. Am. Mus. nat. Hist., vol. 109 , p. $239-319$, est. 21.

1959. Catalogue of the polychaetous annelids of the world. Parts 1 \& 2. Occ. Pap. Allan Hancock Fdn, vol. 23, p. 1-628.

1961. Polychaetous annelids from California. Allan Hancock Pacif. Exped., vol. 25, p. 1-226, est. 1-34.

1964. Polychaeta Errantia of Antarctica. Antarctic Res. Ser., vol. 3, xi +131 p., 39 ests., 1 mapa.

1965 Deep water benthic polychaetous annelids off New England to Bermuda and other North Atlantic areas. Occ. Pap. Allan Hancock Fdn, vol. 28, 378 p. 52 ests.

1966. Polychaeta Myzostomidae and Sedentaria of Antarctica. Antarctic Res. Ser., vol. 7, p. 1-158, 46 ests., 5 mapas.

1968. Atlas of the Errantiate polychaetous annelids from California. Los Angeles, Allan Hancock Fdn, 828 p.

Hessle, C.

1917. Zur Kenntnis der terebellomorphen Polychaeten. Zool. Bidr. Upps., vol. 5, p. 39-258, est. 1-5, 66 figs.

IMAJIMA, M. 1966.

The Syllidae from Japan. Part 5. Syllinae (2). Publs Seto mar. biol. Lab., vol. 15 , n.o 4 , p. $253-294$, fig. $50-65$.

IMAJIMA, M. \& HARTMAN, O.

1964. The polychaetous annelids of Japan. Occ. Pap. Allan Hancock Fdn, vol. 26, p. 1-452, est. $1-38$.

IZUKA, A

1912. The errantiate Polychaeta of Japan. J. Coll. Sci. imp. Univ. Tokyo, vol. 30, art. 2, p. 1-262, 24 ests.

JOHANSSON, K, E.

1927. Beiträge zur Kenntnis der Polychaeten-Familien Hermellidae, Sabellidae und Serpulidae. Zool. Bidr. Upps., vol. 11, p. $1-184,5$ ests., 15 figs.
JoHnson, H. P

1901. The Polychaeta of the Puget Sound region. Proc. Boston Soc. nat. Hist., vol. 29 , p. 381-437, est. 1-19.

JoNES, M. I. 1962 .

On some polychaetous annelids from Jamaica, the West Indies. Bull. Am. Mus. nat. Hist., vol. 124 , p. $169-212$, fig. $1-146$, 52 ests., 1 mapa.

KINBERG, J. G. H.

1910. Kongliga Svenska Fregatten "Eugenies" Resa omkring jorden under befäl af C. A. Virgin aren 1851-1853. Zoologi. 3. Annulater. 78 p., 29 ests.

KNox, G. A.

1960. Polychaeta Errantia. Biological results of the Chatham Islands 1954 Expedition. Bull. N. Z. Dep. scient. ind. Res., vol. 139, n. 3 , p. $77-143,238$ figs.

LANGERHANS, $\mathrm{P}$

1879 Die Wurmfauna von Madeira. Z. wiss. Zool., pt. 1, vol. 32 , p. 513-592, est. 31-33 .

1880. Die Wurmfauna von Madeira. Z. wiss. Zool., pt. 2, vol. 33, p. 267-316, est. 14-18.

1881. Die Wurmfauna von Madeira. Z. wiss. Zool., pt. 3, vol. 34, p. 87-143, est. 4-6.

1884. Die Wurmfauna von Madeira. Z. wiss. Zool., pt. 4, vol. 40 , p. 247-285, est. 15-17.

LUNA, A.

1969. Shelf off Alagoas and Sergipe (Northeastern Brazil). 4. Polychaetous annelids (preliminary report). Trabs. oceanogrs. Univ. Fed. Pe., vol. 9/11, p. 193-222.

Mabessone, J. M. \& Tinoco, I.

1967. Shelf off Alagoas and Sergipe (Northeastern Brazil). 2. Geology. Trabs. oceanogrs. Univ. Fed. Pe., vol. 7/8, p. 151-186 .

MALMGREN, A. J.

1865/66 Nordiska Hafs-Annulater. Forh. Oefv. K. Vetensk. Akad. Stockholm, vol. 21, p. $51-110,181-192$, est. $8-15$; vol. 22 , p. p. $355-410$, est. $18-29$.

1867. Annulata Polychaeta Spetsbergiae, Groenlandiae, Islandiae et Scandinaviae hactenus cognita. Forh. Oefv. K. Vetensk. Akad. Stockholm, vol. 24, p. 127-235, est. 2-15.

McIntosh, W. C.

1885. Report on the Annelida Polychaeta collected by H. M. S. "Challenger" during the years 1873-76. Challenger Rep., vol. 12 , p. $1-554$, est. $1-55$ e $1 \mathrm{a}-39 \mathrm{a}$.

1900. A monograph of the British annelids. vol. 1, pt. 2. Polychaeta. Amphinomidae to Sigalionidae. London, Ray Soc., p. 215-442, est. $24-42$

MONRo, C. C. A.

1924. On the Polychaeta collected by H. M. S. "Alert", 1881-1882. Families Polynoidae, Sigalionidae and Eunicidae. J. Linn. Soc., vol. 36, p. 37-64, 24 figs. 
1928.

Papers from Dr. Th. Mortensen's Pacific Expedition, 1914-16. On the Polychaeta collected by Dr. Th. Mortensen off the coast of Panama. Videnskd. Meddr dansk naturh. Foren., vol. 85, p. 75-103, 19 figs.

1933. The Polychaeta Errantia collected by Dr. C. Crossiand at Colon in the Panama region and the Galapagos Islands during the expedition of the S. Y. "St. George". Proc. zool. Soc. Lond., pt. 1, p. 1-96, 36 figs.

1933a. The Polychaeta Sedentaria collected by Dr. C. Crossiand at Colon in the Panama region and the Galapagos Islands during the expedition of the S. Y. "St. George”. Proc. zool. Soc. Lond., pt. 2, p. 1039-1092, fig. 1-31.

1936. Polychaete worms. II. Discovery Rep., vol. 12 , p. $59-198,34$ figs.

MOORE, J. P

1909. Polychaetous annelids from Monterey Bay and San Diego, California. Proc. Acad. nat. Sci. Phuad., vol. 61, p. 235-295 , est. $7-9$

MÜlLLeR, F.

1858. Einiges über die Anneliden fauna der Insel St. Catharina an der Brazilianischen Kuste. Arch. Naturgesch., vol. 24, p. 211-220, est. 6-7.

Nonato, E.

1966. Anelídeos poliquetas da campanha científica do pesqueiro "Pescal II". Bolm Inst. oceanogr. S Paulo, vol. 15 , n. ${ }^{\circ}$, p. 65-74 , fig. $1-12$.

1966a. Sternaspis capillata sp. n. (Annelida, Polychaeta). Boim Inst. oceanogr. S Paulo, vol. 15 , n. ${ }^{\circ} 1$, p. $79-83$.

Nonato, E. \& LUNA, A.

1969. Sôbre alguns poliquetas de escama do nordeste do Brasil. Bolm Inst. oceanogr. S Paulo, vol. 18, p. 63-91.

Pettibone, M. H.

1948. Two new species of polychaete worms of the family Polynoidae from Puget Sound and San Juan Archipelago. J. Wash. Acad. Sci., vol. 38, p. 412-414, 2 figs.

1953. Some scale-bearing polychaetes of Puget Sound and adjacent waters. Seattle, 89 p. 40 ests. (Mimeo.)

1963. Marine polychaete worms of the New England region. I. Aphroditidae through Trochochaetidae. Bull. U.S. natn. Mus., n. 227 (1), p. 1-356, fig. 1-83.

1966. Revision of the Pilargidae (Annelida: Polychaeta), including descriptions of the pelagic Podarmusploa Chamberlin. Proc. U.S. natn. Mus., vol. 118, p. 155 $-208,26$ figs.

1967. Type-sfecimens of polychaetes described by Edith and Cyril Berkeley (1923-1964). Proc. U.S. natn. Mus., n. ${ }^{\circ} 3553$, vol. 119 , p. 1-23.
1969. Revision of the aphroditoid polychaetes of the family Eulepethidae Chamberlin (Eulepidinae Darboux; = Pareulepidae Hartman). Smithson. Contr. Zool., n. 41, p. 1-44, fig. 1-31.

Pruvot, G.

1930.

Annélides polychètes de Nouvelle-Caledonie recuillies par M. Francois. Archs Zool. exp. gén., vol. 70, p. 1-94, 8 figs., 3 ests.

Renaud, J. C.

1956. A report on some polychaetous annelids from the Miami-Bimini area. Am. Mus. Novit., n. ${ }^{\circ} 1812$, p. $1-40$, fig. $1-21$.

RIOJA, E.

1941. Estudios anelidológicos. II. Observaciones acerca de varias especies del genero Hydroides Gunnerus (sensu Fauvel) de las costas mexicanas del Pacifico. An. Inst. Biol. Univ. Méx., vol. 12, p. 161$-175,4$ ests.

1944. Estudios anelidológicos. X. Estudio de algunos poliquetos del Museo Argentino de Ciencias Naturales. An. Inst. Biol. Univ. Méx., vol. 15, p. 115-138, 62 figs.

RULLIER, F

1964. Résultats scientifiques des campagnes de la "Calypso". Iles du Cap Vert. Annélides polychètes. Annls Inst. océanogr. Monaco, vol. 41, fasc. 6, p. 113-218.

1964a. Contribution à la faune des annélides polychètes du Cameroun. Bull. Inst. fr. Afr. noire, vol. 26, p. 1071-1102, figs. $1-4$.

1965. Contribution à la faune des annélides polychètes du Dahomey et du Congo. Cah. ORSTOM - Oceanogr., vol. 3 , n. 3 , p. 5-66, 12 figs., 1 mapa.

SAVignY, J. C.

1820. Système des annélides, principalement de celles des côtes de l'Egypte et de la Syrie. Hist. Nat., Paris, Panckouche, p. 325-472.

SchMARDA, L. K.

1861 Neue wirbellose Thiere, Turbellarien, Rotatorien und Anneliden, vol. 1, pt. 2, p. 1-164, 100 figs., 22 ests.

ST. Joseph, A

1906. Les annélides polychètes des côtes de France (océan et côtes de Provence). Annls Sci. nat., sér. 9 , vol. 3, p. 145-260, est. 1-5.

TEBble, $N$. 1952 .

1953 A review of the genus Ophelia (Polychaeta) with descriptions of new species from South African and Californian waters. Ann. Mag. nat. Hist., ser. 12, vol. 6, p. 361-368, 1 fig.

1955. The polychaete fauna of the Gold Coast Bull. Br. Mus, nat. Hist., Zool., vol. 3, n. ${ }^{\circ}$, p. $61-148,30$ figs. 
Treadwell, A. L.

1901. The polychaetous annelids of Porto Rico. Bull. U.S. Fish Commn, vol. 20, p. 181-210, 81 figs.

1911. Polychaetous annelids from the Dry Tortugas, Florida. Bull. Am. Mus. nat. Hist., vol. 30 , p. $1-12,29$ figs.

1917. Polychaetous annelids from Florida, Porto Rico, Bermuda and the Bahamas. Publs Carnegie Instn Wash., n. 251 , p. 255-272, 3 ests.

1921. Leodicidae of the West Indian region. Publs Carnegie Instn Wash., n. ${ }^{\circ} 293,131$ p. 467 figs., 9 ests.

1924. Polychaetous annelids collected by the Barbados-Antigua Expedition from the University of Iowa in 1918. Univ. Iowa Stud., vol. 10 , n. ${ }^{\circ} 4$, p. $1-23,2$ ests.

1929. Acoetes magnifica, a new species of polychaetous annelid from Montego Bay, Jamaica, British West Indies. Am. Mus. Novit., n. ${ }^{\circ} 355,4$ p. 7 figs.

1929a. New species of polychaetous annelids in the collections of the American Museum of Natural History, from Porto Rico, Florida, Lower California, and British Somaliland. Am. Mus. Novit., n. ${ }^{\circ}$ 392, 13 p. 36 figs.
1934. New polychaetous annelids. Smithson. misc. Collns, vol. 91 , n. ${ }^{\circ} 8,9$ p., 2 ests.

1936. Polychaetous annelids from the vicinity of Nonsuch Island, Bermuda. Zoologica, N.Y., vol. 21 , n. ${ }^{\circ} 2$, p. $49-68,3$ ests.

1937. The Templeton Crocker Expedition. Polychaetous annelids from the west coast of Lower California, the Gulf of California and Clarion Island. Zoologica, N.Y., vol. 22, p. 139-160, 2 ests.

1939. Polychaetous annelids of Porto Rico and vicinity. Scientific survey of Porto Rico and the Virgin Islands. Acad. Sci., N. Y., vol. 16, n. ${ }^{\circ}$, p. 151-319, 118 figs.

WEBSTER, H. E.

1879. Annelida Chaetopoda of the Virginian coast. Trans. Albany Inst. N.Y., vol. 9, p. 202-269, 11 ests.

1884. Annelida from Bermuda. Bull. U.S. natn. Mus., n. ${ }^{\circ}$ 25, p. 305-327, est. 7-12.

WESENBERG-LUND, E.

1962. Reports of the Lund University Chile Expedition 1948-49. 43. Polychaeta Errantia. Lund Univ. Arsskr., N.F. Avd. 2 , vol. 57 , n. 12 , p. $1-199$, fig. $1-49$. 